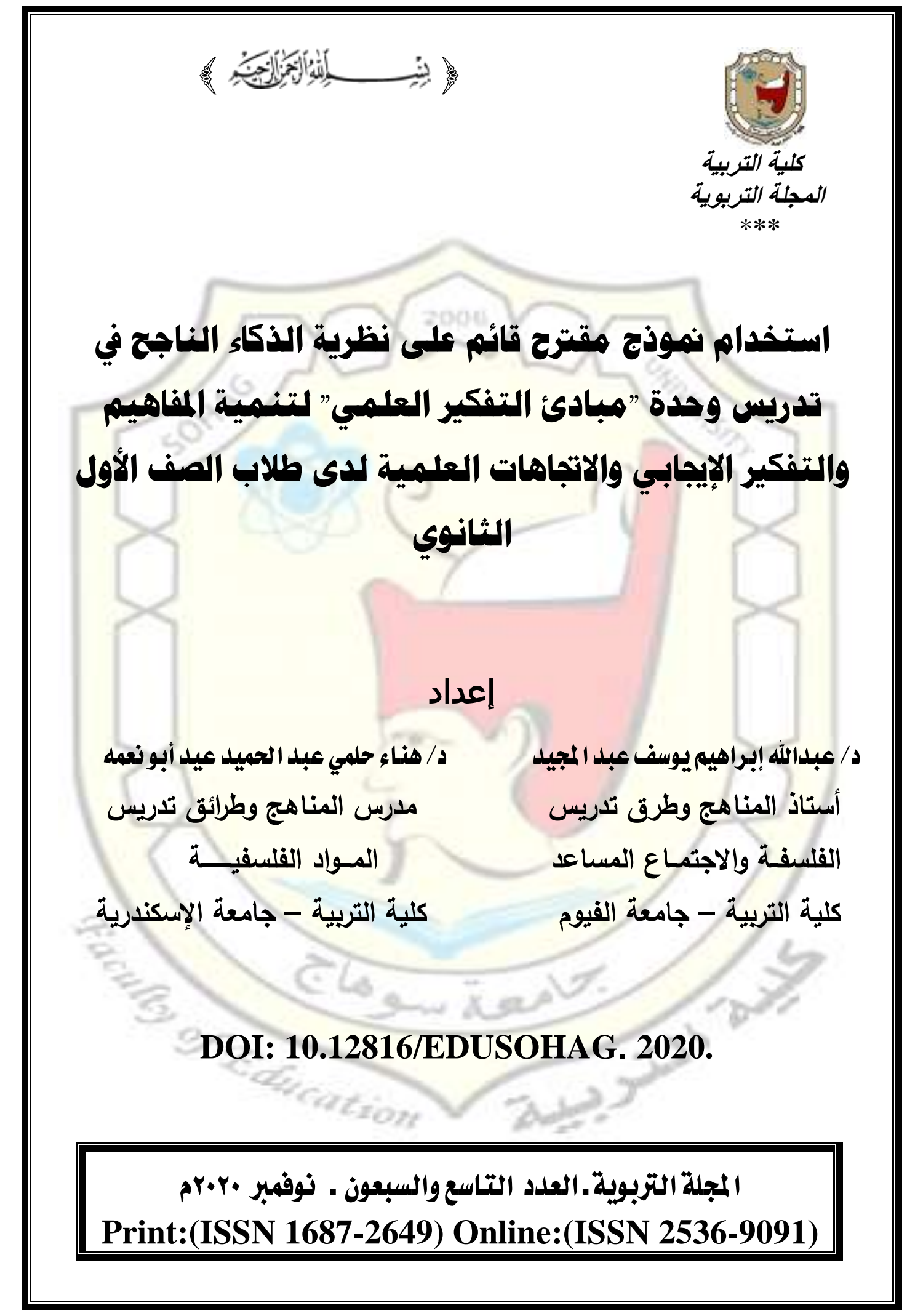




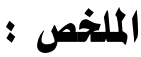

هاف البحث إلى قياس فعالية استخدام نموذج مقترح قائم على نظرية الذكاء الناجح في تدريس وحدة "مبادئ التفكير العلمي" على تنمية المفاهيم والتفكير الايجابي والاتجاهات العلمية لاى طلاب الصف الأول الثانوي ـ وقد استخدم كلا من المنهج الوصفي لعرض الإطار

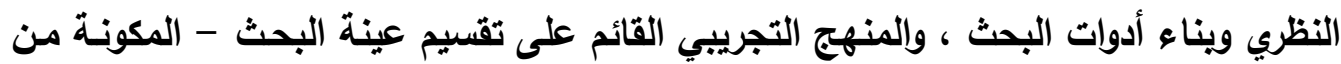

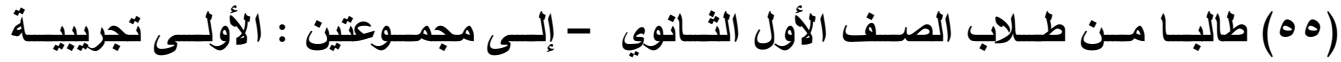

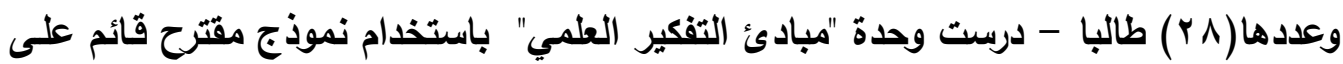
نظريـة الذكاء النـاجح ، والثانيـة ضـابطة وعددها (rV ) طالبـا درست نفس الوحدة بالطريقة

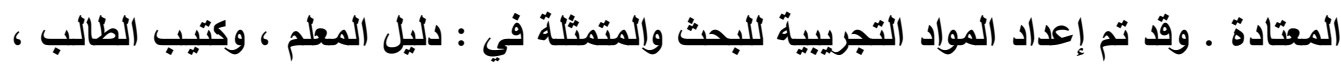
وأيضـا إعداد أدوات القيـاس المتمثــة في : اختبـار المفـاهيم ، واختبـار التفكير الإيجـابي ، ومقيـاس الاتجاهـات العلميـة ـ ومـن خـلال إجـراء تجريـة البحث ورصد النتائج وتفسيرها ، أظهرت النتائج فاعلية استخدام النموذج المقترح القائم على نظرية الذكاء الناجح في تلدريس وحدة "مبـادئ التفكير العلمي"على تنميـة المفـاهيم العلميـة والمنطقيـة، والتفكير الايجـابي، والاتجاهات العلمية لاى طلاب الصف الأول الثانوي .

الكلمات المفتاحية : نموذج مقترح - نظرية الذكاء الناجح - وحدة مبادئ التفكير العلمي - المفاهيم - التفكير الإيجابي - الاتجاهات العلمية - طلاب الصف الأول الثانوي . 
استخدام نموذج مقترح قائم على نظرية الذكاء الناجح

Using a successful intelligence based model in teaching the scientific thinking principles unit to develop first year secondary students concepts, positive thinking and scientific attitude

Dr/ Abdullah Ibrahim Yousief Abdel-Mageed

Dr/Hanaa Helmy Abdel Hamid Eid Abu Nima

\begin{abstract}
:
The Study aimed at measuring the effectiveness of using successful intelligence theory in teaching "principles of scientific thinking" unit on developing first year secondary students' concepts, positive thinking and scientific attitude. The descriptive method was used for the review of literature and theoretical background as well as in designing the study tools, while the two groups' experimental design was used for the experimentation. The study sample included 55 first year secondary students and was divided into an experimental one ( 28 students) who studied the selected unit using a successful intelligence theory based model while the control group (27 students) used the usual way. The study utilized the following tools: Teacher's guide, Students' book, concepts test, Positive thinking test, scientific attitude measure. The study proved the effectiveness of the suggested model on developing first year secondary students' concepts, positive thinking and scientific attitude.
\end{abstract}

Key words:

A suggested model- Successful Intelligence Theory - Principles of Scientific Thinking Unit-concepts- positive thinking - Scientific Attitude - First Year Secondary Students. 
مقدمة :

نظراً للتطور الهائل الذي طرأ على المناهج الدراسية المختلفة في السنوات الأخيرة والذي اتسم بالزيادة الهائلة في كم المعرفة ونوعها، فقد أصبح الإلمام بمكونات هذه المعرفة بواسطة الطرق التقليدية أمراً صعباً، لذلك ظهرت اتجاهات جليدة تنادي بأهمية التأكيد على إدراك وفهم أساسيات المعرفة العلمية ، وما يرتبط بها من مفاهيم وحقائق وقيم واتجاهات، بالإضافة

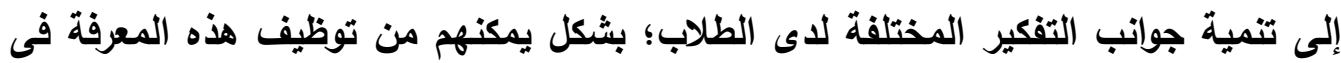
مختلف مجالات الحياة اليومية . ويعد البناء المفاهيمى للمتعلم من العوامل الاساسية التى تؤثثر في فاعلية التدريس ، فامتلاك الطالب لبنية الموضوع المعرفى يمكنه من التصرف بالمعرفة وتحويرها ، وتوليد معرفة جديدة منها ، أو استبصار علاقات جديدة بين عناصرها ـ فالمفاهيم توظف المعرفة في حل المشكلات ، مما يزيل من فاعلية المعرفة لايه وينمى قوته العقلية ـ وامتلاك البنية المعرفية يزيد من قدرة المتعلم على الاحتفاظ بالمعرفة واستخدامها عند الحاجة ، كما يوفر له دافعا ذاتيا يساعده في فهم المادة الدراسية وإنتقال أثر التعلم (أريج سليمان عمر ، عدنان سالمانه

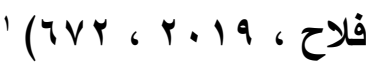
وفى ضوء ذلك أصبحت المناهج القائمة على مفاهيم العلم من أهم الاتجاهات فى ميدان المناهج العامة ، وقد أخذت بهذا الاتجاه مناهج المواد القلسفية في دول عديدة ـ وإذا كان تعلم المفاهيم القلسفية بشكل عام يسهم في فهم وتعلم القلسفة كمادة دراسية، فهو أيضًا يسهم في تعلم مجموعة المفاهيم التي يجدها الطالب في المواد الدراسية الأخرى؛ وذلك باعتبار أن هذه المواد مبنية في الأساس على مجموعة من التصورات القلسفية. وتعلم

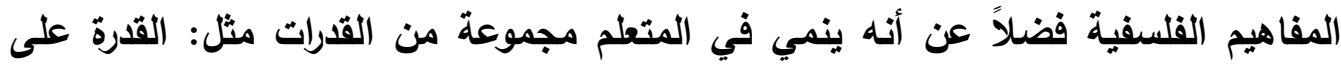

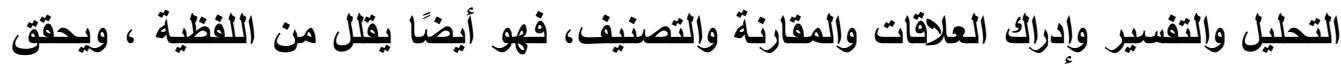
الوظيفية ، ويساعد على ريط المواد الدراسية بعضها ببعض ، فيحقق بذلك مفهوم التكامل

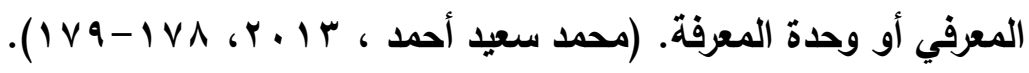

يتم التوثيق كالتالي ( أسم المؤلف أو الباحث ، يليه سنة النشر ، ثم رقم الصفحة أو الصفحات التي تم الرجوع 
ونظراً لأن تعلم الدفاهيم هدف تريوي هام في جميع مستويات التعليم ، لذلك يعمل المطلمون وخبراء المناهج ومعدو المواد التعليمية في دأب ومثابرة على تحديد المفاهيم التي يتعلمها الطلاب في مراحل التعليم على اختلافها، بل يبذلون جهوداً كبيرة لتطوير المواد

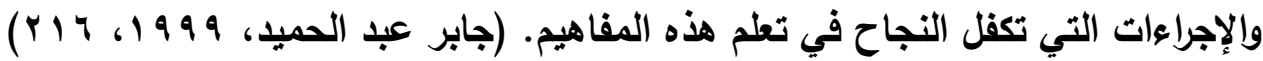
ويمثل تنمية المفاهيم داخل مجال المواد الفلسفية أهمية كبيرة ، ففي مجال الفلسفة تعد فيدائ واحدة من أهم جواتب التعلم ؛لأنها تعتبر بمثابة مفاتيح للتفكير الفلسفي ، كما أنها تنمى لاىى المتعلم مجموعة من القدرات المتنوعة.ومن ثم يتطلب التخطيط للمنهج القائم على المفاهيم

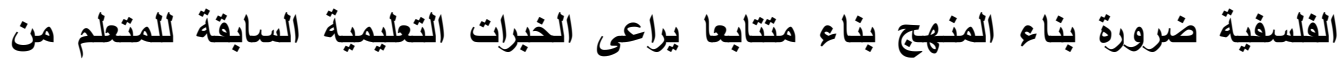

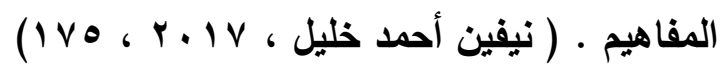
كذلك تبدو أهمية تعلم المفاهيم الخاصة بمادة المنطق في أنها تمكن من إرساء وتعميق النيق

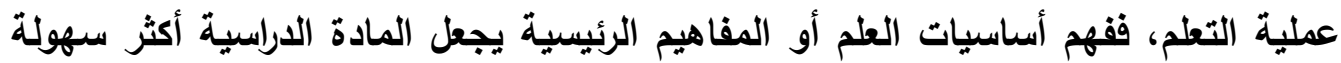

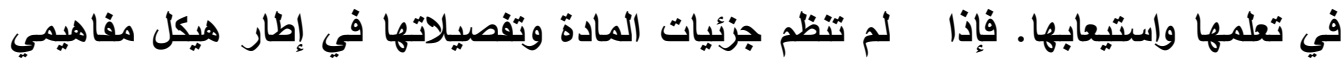
تنسي بسرعة، وذلك على اعتبار أن فهم المبادئ والمفاهيم هو الأسلوب الوحيد لزيادة فعالية

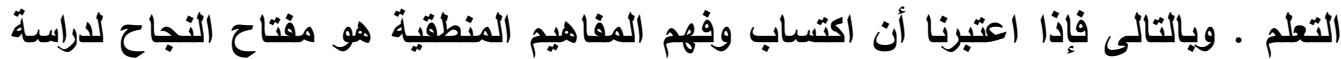

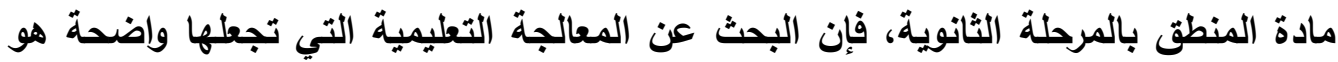

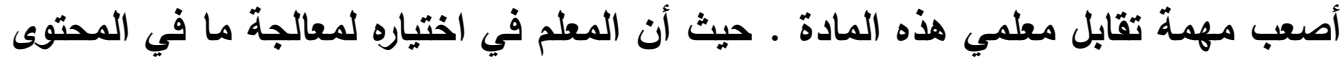

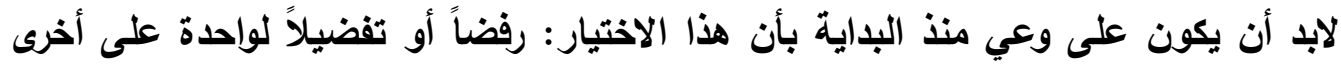

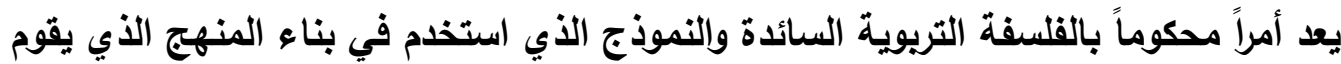

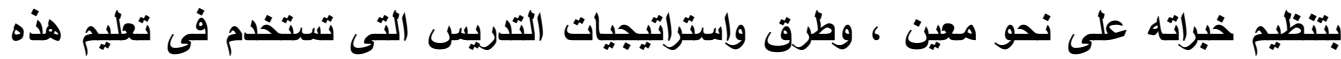
المفاهيم ، بحيث يتمكن الطلاب من دراستها واستيعابها بسهولة ويسر. (مواهب السيدات

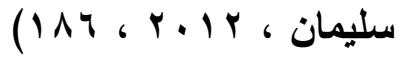
وتأكيدا لأهية تعلم المفاهيم ، فقد اتجهت العليد من الدراسات إلى استخدام مناهج مقترحة ومداخل واستراتيجيات حديثة لتنمية تلك المفاهيم لاى الطلاب في مراحل التعليم

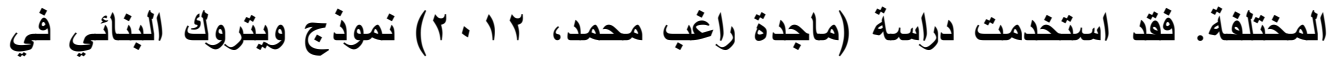
تنمية المفاهيم المنطقية والتفكير المنطقي لدى طلاب المرحلة الثانوية ، وأيضا هدفت دراسة

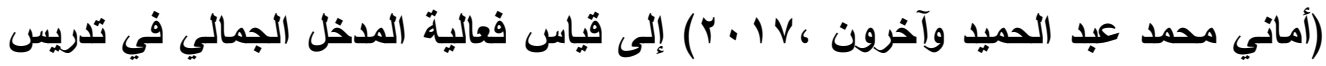


البيولوجي لتنمية بعض المفاهيم العلمية الكبرى وآراء الطلاب والمعلمين بالمرحلة الثانوية

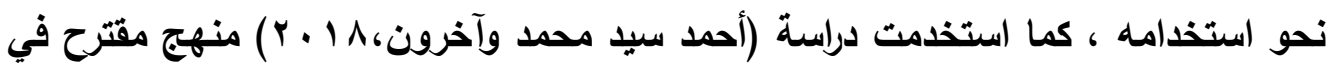
البيولوجي قائم على مدخل الاستقصاء متعدد النظم لتنمية المفاهيم العلمية ومهارات التفكير

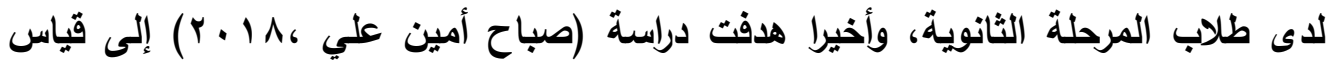
فاعلية برنامج مقترح قائم على نموذج فراير على تنمية المفاهيم المنطقية الأساسية والكفاعة الأتية المدركة ويقاء أثر التعلم لاى الطالبات المعلمات شعبة فلسفة واجتماع ـ ورغم الأهمية السابقة لتعلم وتنمية المفاهيم ، إلا أن بعض الدراسات السابقة قد أكدت وجود ضعف في إتقان وفهم المفاهيم المتضمنة في مناهج المواد القلسفية بالمرحلة الثانوية • فقد أوضحت بعض الدراسات وجود قصور وضعف في تعلم المفاهيم المنطقية لاى طلاب المرحلة الثانوية ، ومنها : مثل دراسة (مواهب السيد سليمان ، Y ب ب) ، ودراسة (محمد

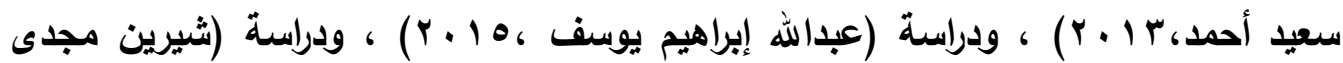

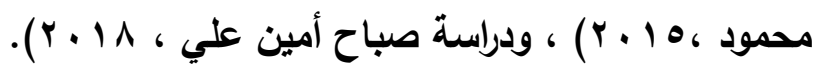
وكذللك أوضحت بعض الدراسات الأخرى وجود قصور وضعف في تعلم المفاهيم القلسفية ،

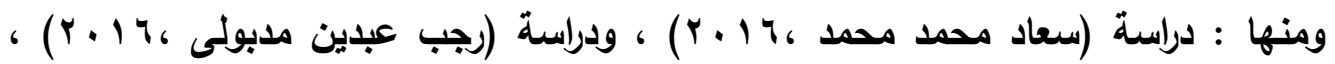

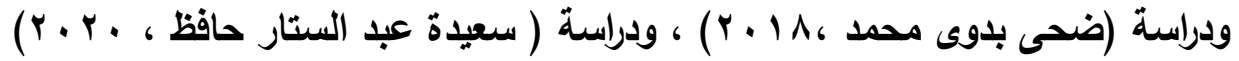
وأخيرا أوضحت بعض الدراسات وجود قصور وضعف فى تعلم المفاهيم العلمية لدى طلاب المرحلة الثانوية ، ومنها : دراسة ( هلى محمد حسين ، وهنادي عبدالله سعود

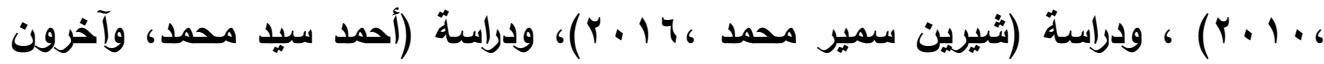

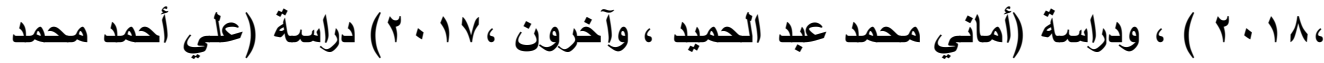

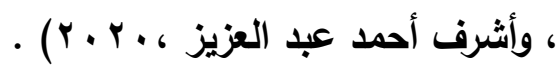
وتأكيدا لما سبق فقد أجرى الباحثان دراسة استطلاعية على عينة عشوائية من طلاب الصف الأول الثانوي، وعددهم (r^) طالب بمدرسة جمال عبد الناصر الثانوية التابعة لإدارة

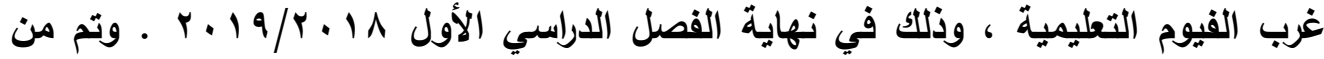
خلالها تطبيق اختبار في المفاهيم المتضمنة في وحدة مبادئ التفكير الفلسفي " من كتاب " مبادئ التفكير الفلسفي والعلمي " لطلاب الصف الأول الثانوي" . وقد هدف الاختبار إلى 
قياس ثلاثة مفاهيم رئيسية وهى : التفكير الإنساني ، الفلسفة ، التفكير الفلسفي • ويمكن عرض توزيع أعداد الطلاب ونسبتهم المئوية وفقا لارجاتهم في الاختبار من خلال جدول رقم

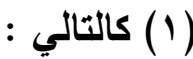

جدول (1)

نتائج الاراسة الاستطلاعية لاختبار المفاهيم

\begin{tabular}{|c|c|c|c|}
\hline \multicolumn{3}{|c|}{ توزيع الطلاب وفقا لدرجاتهم على الاختبار } & \multirow{2}{*}{ العدد والنسبة } \\
\hline 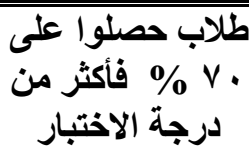 & طن طلاب حصلوا كاتت درجاتهة & طن اب حصلوا على أقلّ من درجة & \\
\hline 1 & 19 & Ir & عدد الطلاب \\
\hline$\%$ \%४.५ & $\% \leq r .1$. & $\%+1.0 V$ & النسبة المئوية \\
\hline
\end{tabular}

ومن خلال جدول (1) يتضح أن أداء ومستوى فهم وإستيعاب طلاب الصف الأول الثانوي للمفاهيم الفلسفية يعد متوسطا من الناحية الرياضية الإحصائية ـ لكنه يعد مستوى منخفض بالنسبة لأهمية إتقان وتعلم الطالب للمفاهيم الرئيسية في أي مادة دراسية، حيث أنها تعد الهاف المعرفي الرئيسي للمادة الدراسية ، والعامل المحوري لتحقيق باقي نواتج

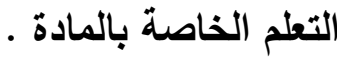

وعلى الرغم من أن تنمية وتعلم المفاهيم يرتبط بالعديد من أنماط التفكير التي يجب تنميتها لاى الطلاب في المرحلة الثانوية ، إلا أن النظرة الواعية لما يحيط بالوطن من مشاكل متتالية ، وتفاقم ما تمر به مصر اليوم من زيادة حالات التفكك الاجتماعي ، ووجود مشكلات على مستوى الأسرة والمجتمع تجعلنا في أمس الحاجة إلى التفكير الايجابي ، الذي قد يساعد

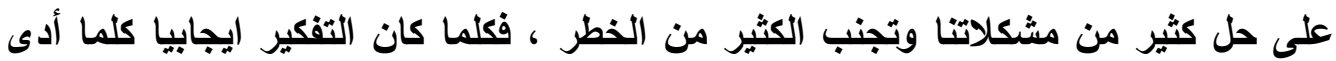
إلى حل فعال للمشكلات ، وكلما كان التفكير سلبيا كلما أدى إلى التعامل مع هذه المشكلات بأساليب سطية وخاطئة ، سواء كان ذلك بتضخيم المشكلات أو المبالغة في التعامل معها أو تبسيطها واختزالها ، ويالتالي عدم الوصول إلى حل مقنع لها. (سامية لطفي الأنصاري (0. $\left.r^{\prime}\right) r_{6}$

ويشير كل من (Bekhet \& Zauszniewski,2013,1076) إلى أن التفكير الإيجابي هو عملية معرفية تتضمن تظوير وإنتاج مجموعة من الصور والأفكار المتفائلة ، وإيجاد حلول مناسبة للمشكلات ، واتخاذ قرارات حاسمة بشأن المشكلات الموجودة ـ كذلك تتضمن 
هذه العملية إنتاج نظرة مشرقة شاملة للحياة. ويالإضافة إلى ذلك ، فإن التفكير الإيجابي لا يتجاهل الحاجة إلى التقييم الواقعي ، ويقر بالجوانب السلبية والإيجابية للقضايا والأحداث والمواقف ، ثم يفضل التحرك نحو التركيز الإيجابي وتفسير حدوثها ـ

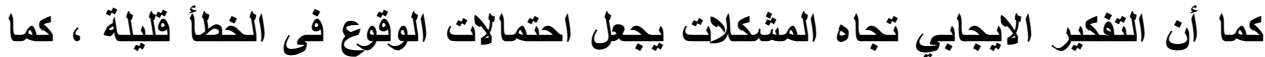
أنه يخفف أو يحد من اتخاذ القرارات المتسرعة ، والتى تتتج عنها أخطاء جسيمة ـ (أبو بكر

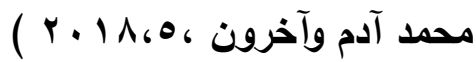
ويشير (توفيق زايد) بأن التفكير الايجابي ليس مجرد مصطلح آخر يضاف إلى غيره من المصطلحات ، وليس أسلويا جديدا من أساليب التفكير العصري ، ولكنه الطريق إلى حياة ناجحة ، وإلقاء الضوء على جوانب القوة في الشخصية من أجل تحقيق المزيد من الأهداف عن طريق تنمية القدرات والاتجاهات ، وإثراء المواقف لتصبح أكثر فاعلية ونجاحا ـ ( أرزلق

$$
\text { محمد عطية }
$$

ويرى الباحثان أن أهمية التفكير الايجابي تكمن فى أنه نمط من أنماط التفكير يرتقى بالفرد ويساعده على استثمار عقله ومشاعره وسلوكه، واكتثاف قواه الكامنة ، وتغيير حياته نحو الأفضل من خلال التوجه الايجابي فى الحياة،والنزوع إلى التوقعات الايجابية للنجاح والسعادة والانجاز، والسيطرة والتحكم فى مجريات الأحداث والتعلم من ضغوط الحياة،والخروج منها بأقل الخسائر،وتوظيف المرونة العقلية في المواقف المحرجة،واستخدام خطوات إبداعية للوصول إلى حلول مرضية للمشكلات .

وتأكيدا لأهمية التفكير الإيجابي ، فقد اتجهت العديد من الاراسات إلى استخدام مناهج مقترحة ومداخل واستراتيجيات حديثة لتنمية مهاراته وأبعاده لاى الطلاب في مراحل التعليم المختلفة ، وأيضا أوضحت بعض الاراسات الأخرى علاقته ببعض نواتج التعلم الأخرى.فق أكدت دراسة (Paxton,2008) أن التفكير الايجابي لدى المراهقين نحو المستقبل يؤثر على توقعاتهم الايجابية نحو المدرسة والدراسة الأكاديمية ، كذلك يرتبط باتجاههم نحو بعض الظواهر الاجتماعية السلبية كالانتحار ،وأكلت دراسة (2011, Fang) وجود علاقة ايجابية بين الكفاعة الأتية لاى طلاب الجامعة وتفكيرهم الايجابي ، كما أوضحت دراسة (أن تصميم برامج تعليمية وسلوكية قائمة على مهارات التفكير الايجابي يخفض من مشاعر القلق والاكتئاب لدى تلاميذ المرحلة المتوسطة ، وأكلات 
دراسة (Pallister \&et...al, 2014) فاعلية برنامج قائم على مهارات التفكير الإيجابي فى تحسين التعلم الاجتماعي والعاطفي في مرحلة الطفولة المتوسطة ، وكنلك أوضحت

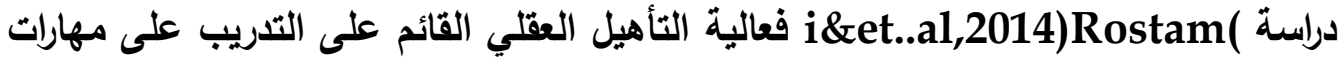
التفكير الإيجابي على زيادة مثاعر السعادة لاى المراهقين ذوي الإعاقة السمعية ، وأيضا أثبتت دراسة (Çelik \& Sariçam,2018) وجود علاقة ارتباطيه بين التفكير الايجابي ويين اتجاهات الضبط الأكاديمي (داخلي - خارجي) لاى طلاب المرحلة الثانوية ، كما

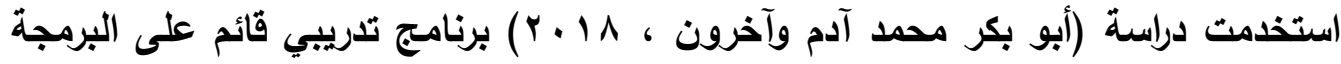

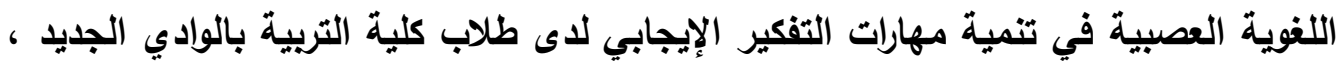

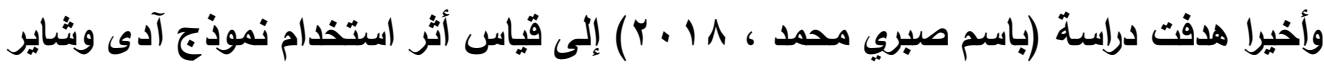
Adey,Shayer نحو المشاركة الوجدانية لاى تلاميذ المرحلة الإعدادية . ولكن رغم الأهمية السابقة لتنمية التفكير الإيجابي لاى الطلاب في مراحل التعليم المختلفة ، إلا أن بعض الدراسات السابقة أوضحت وجود ضعف في مهارات التفكير الايجابي لاى طلاب المرحلة الثانوية ، ومنها : دراسة (ثيماء مصطفى مصطفى ، ومروة عبد الباسط التطابل

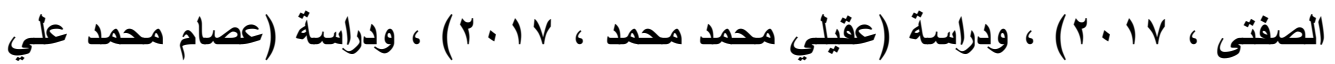

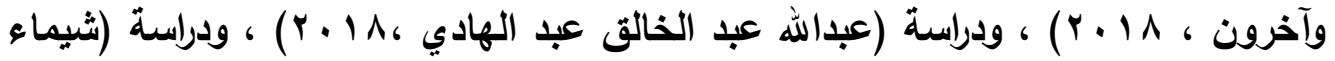

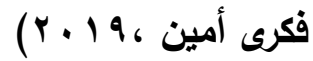

وتأكيدا لما سبق فقل أجرى الباحثان دراسة استطلاعية على عينة عشوائية من طلاب الصف الأول الثانوي، وعددهم (^^) طالب بمدرسة جمال عبد الناصر الثانوية التابعة لإدارة

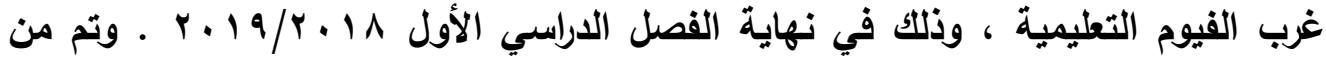
خلالها تطبيق اختبار قصير في التفكير الإيجابي" . حيث اقتصر الاختبار على قياس (ه) (ه)

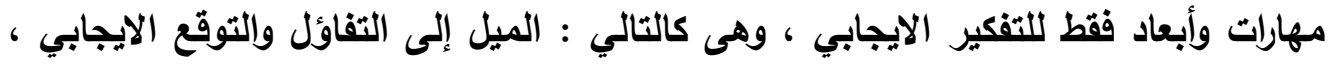

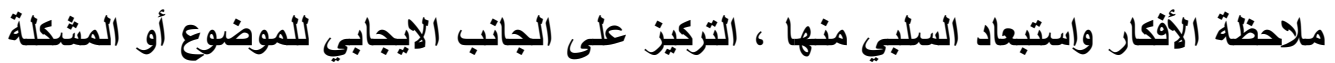

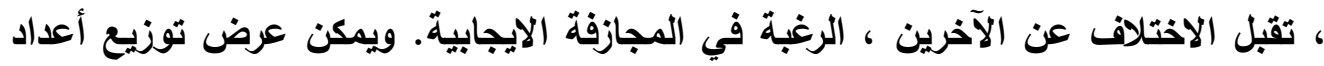
الطلاب ونسبتهم المئوية وفقا لارجاتهم في الاختبار من خلال جدول رقم (ז) كالتالي : 


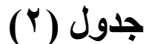

نتائج الدراسة الاستطلاعية لاختبار التفكير الايجابي

\begin{tabular}{|c|c|c|c|}
\hline \multicolumn{3}{|c|}{ توزيع الطلاب وفقا لارجاتهم على الاختبار } & \multirow{2}{*}{ المئوينة } \\
\hline 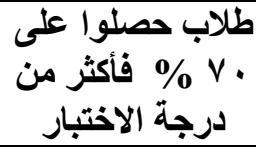 & 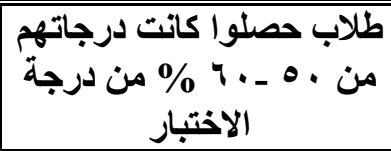 & 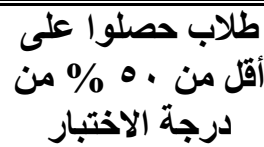 & \\
\hline 9 & Ir & IV & عدد الطلاب \\
\hline \% \% r... & $\%$ \% I.0V & $\%$ \& \&.V & المئوينة \\
\hline
\end{tabular}

ومن خلال جدول (r) يتضح أن أداء ومستوى مهارات التفكير الايجابي لاى طلاب الصف الأول الثانوي يعد متوسطا من الناحية الرياضية الإحصائية ، ولكنه يعد منخفضا بالنسبة لطبيعة مهارات التفكير الإيجابي وطبيعة المرحلة العمرية والدراسية ، حيث أنه من المتوقع أن يكون لاى الطلاب في هذه المرحلة مستوى عال من حيث توقعاتهم ونظرتهم

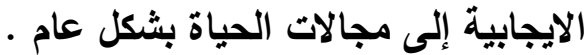
وفى ضوء الأهمية السابقة للتفكير الايجابي ، ويالنظر إلى طبيعة تعلم المفاهيم ، تأتى الاتجاهات العلمية كأحد جواتب التعلم التي يجب تتميتها وإكسابها للطلاب فى المرحلة الثانوية ـ إذ إنها تعبر عن جوهر العلم وتقود الطلاب إلى استخدام ما لايهر من معرفه ومهارات علمية فى المواقف الحياتية المختلفة. ويعد إكساب الطلاب بعض من صفات ذوي الاتجاهات العلمية -غير المتعارضة مع مسلمات العقيدة القطعية - هو نوع من المشاركة في صنع مستقبل فضل، إذ تغدو هذه الصفات جزعا من حياة الفرد والمجتمع اليومية، مما يعنى المشاركة في تربية المجتمع تربية

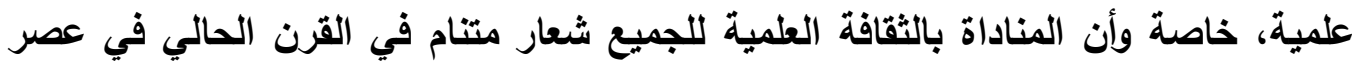
يتسم بالتنافسية. حيث أنه بتربية طلابنا على هذه الاتجاهات نرفع مستوى الإيجابية ونخفض مستوى الإتكالية ، ويإكسابهم إياها يرتفع مستوى تحصيلهم العلمي ، وحبهم للاستطلاع ، وحسن تفسيرهم للظواهر الطبيعية والتخلص من التفسيرات الخرافية، ويتحررون من الجمود المعطل للتفكير ويتريثون في إصدار الأحكام على القضايا والأثياء والأحداث، ويستمتعون بدراسة العلوم الطبيعية، ويتحلون بخلق الموضوعية والدقة والأمانة والمحافظة على الأدوات

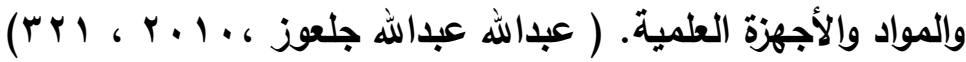


وتأكيدا لأهمية تنمية الاتجاهات العلمية ، فقد اتجهت العديد من الدراسات إلى استخدام مناهج مقترحة ومداخل واستراتيجيات حديثة لتنمية تلك الاتجاهات لاى الطلاب في مراحل

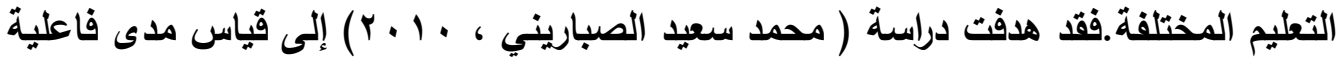
المنحى المنظومي لتدريس الكيمياء على تنمية التفكير العلمي والاتجاهات العلمية لاى طلبة المرحلة الثانوية في الأردن ، وأيضا هدفت دراسة (زهور محمد دحدوح ، 19 • ب) إلى قياس فاعلية تكنولوجيا المطلومات بالجامعات كأحد تقتيات التعلم عن بعد فى تنمية الاتجاهات العلمية لاى طالبات الدراسات العليا "تخصص المناهج وطرق تدريس العلوم " ، وكذلك

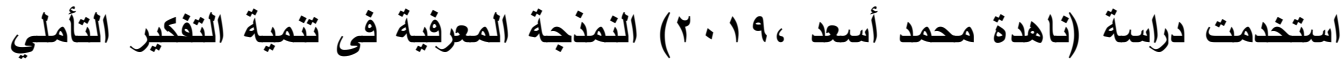
وتحسين الاتجاهات العلمية نحو مادة العلوم لاى طلبة الصف الخامس الابتدائي فى دولة الكويت .

وعلى الرغم من أهمية تنمية الاتجاهات العلمية لدى الطلاب ، إلا أن بعض الدراسات السابقة قد أوضحت وجود ضعف في الاتجاهات العلمية لاى طلاب المرحلة الثانوية ، ومنها:

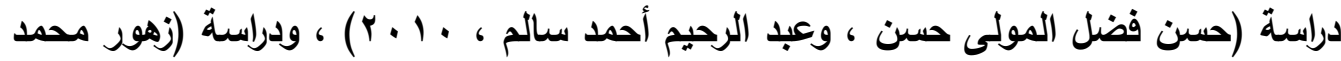

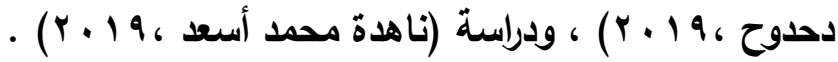
وقد باتت الحاجة ملحة لاستخدام نظريات تعلم حديثة تتواءم مع كم الانفجار المعرفي فى مختلف المجالات ، وذلك من حيث قرتها على تنظيم كم المفاهيم والمعلومات والحقائق التي يتلقاها الطالب أثناء دراسته،بحيث يستطيع استخدام تلك المعرفة فى حل ما يواجهه من

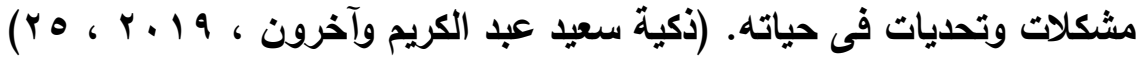
وتعد نظرية الأكاء الناجح للعالم الأمريكي رويرت ستيرنبرج من أهم نظريات التعلم الحديثة التي فرضت نفسها في المجال التريوي في التسعينات من القرن الماضي ، وأظهرت معظم نتائجها دورها الفعال في العملية التعليمية . حيث تعد تلكك النظرية امتدادا لنظريته الثلاثية في الأكاء الإنساني ، وجاءت تتويجا لعدد كبير من الأبحاث والاراسات التي تؤكد أن كل شخص يتميز بقرات معينة تختلف عن الآخرين ، وأن الطلاب يمكن أن يتعلموا بطريقة أكثر فاعلية من الطرق المعتادة ، إذ ما درسوا بطريقة مناسبة لأنماط قدراتهم وتفضيلاتهم المعرفية .

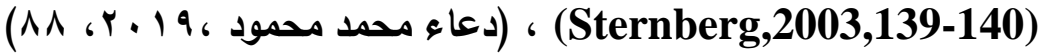


وقد أظهرت نظرية الأكاء الناجح فاعليتها في تنمية مهارات التفكير المختلفة لدى الطلاب فى جميع المراحل التعليمية ، كذلك لها انعكاساتها الايجابية على مستوى التحصيل الدراسي ، بتركيزها على اكتثاف المعلومات بدلا من إعطائهم المعلومات جاهزة (غادة عبد الفتاح عبد

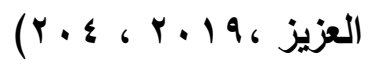

وتشير نظرية الذكاء الناجح أن الأساليب التقليدية في التعلم ، والتي تعتمد على الذاكرة تفشل في تلبية احتياجات الطلاب ، فهي تركز فقط على عدد قليل من الطلاب ذوى قدرات معينة ، وتهمل عدد كبير من الطلاب ممن لايهم قدرات عالية للنجاح ـ ويالتالي فإن التدريس القائم على الأكاء الناجح يتضمن النظر إلى عملية التعليم والتعلم من حيث توسيع نطاق

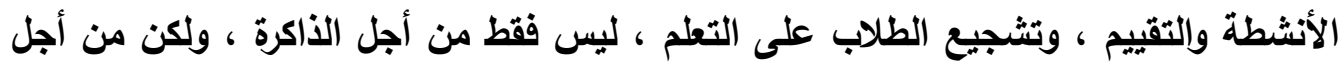
تنمية القدرات التحليلية والإبداعية والعملية. (Rogalla,2003,4-5) وتظهر أهمية استخدام نظرية الأكاء الناجح فى عملية التدريس من خلال ما تحققه من رن فوائد وأهداف تحسن من عمليتي التعليم والتعلم ، والتى من أهمها ما يلي : - التدريس وفق نظرية الذكاء الناجح يساعد الطلاب على ترميز المعلومات والاحتفاظ بها فى الأكرة بطريقة متقنه . - تحفيز الطلاب على التعلم بشكل أكبر وأعمق ، الأمر الأي ينسحب بشكل ايجابي وفاعل على حياتهم المستقبلية . - تساعد الطلاب على اكتشاف نقاط القوة فى أدائهم ، وتصحيح ما لديهم من نقاط ضعف . - تمكن الطلاب من استرجاع المادة المتعلمة بسهولة وقت الحاجة إليها. (عبد الواحد

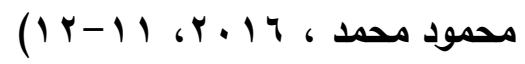
وتأكيا لما سبق فقد أظهرت بعض الاراسات السابقة فاعلية استخدام نظرية الذكاء

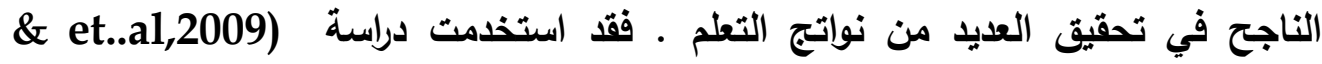
نظرية الأكاء الناجح فى تطوير اختبارات متقدمة لقياس القدرات التحليلية والإبداعية والعملية لاى طلاب المرحلة الثانوية فى مادة الفيزياء ، وأوضحت درئ دراسة (Ding,2010) دراسة (2014, Samavatian \& Latifi) أن تدريب طلاب الجامعة على برامج الذكاء 
الناجح يزيد من التوقع الايجابي للنجاح الأكاديمي ، وأيضا أكدت دراسة ( نشوة محمد

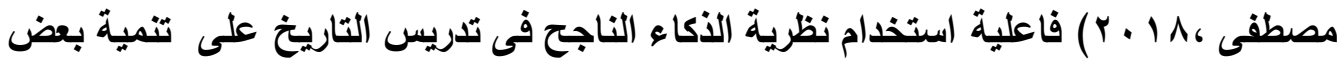
القيم الاقتصادية وجودة الحياة لاى طلاب الصف الأول الثانوي ، كذلك أوضحت دراسة (Mysore\& Vijayalaxmi,2018) التحصيل المعرفي للطلاب وزيادة كفاعتهم التحصيلية والأكاديمية ، كما أنه يمكن استخدامها

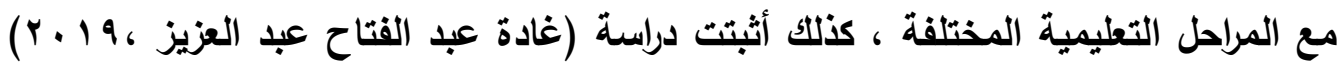
فاعلية برنامج قائم على نظرية الذكاء الناجح فى تنمية مهارات التفكير التاريخي لاى طلاب المرحلة الثانوية ، وأكلت دراسة (دعاء محمد محمود ، 9 ـ ب ب) فاعلية نموذج تدريسي مقترح فى ضوء نظرية الأكاء الناجح على تنمية الفهم العميق وحب الاستطلاع الجغرافي لاى طلاب

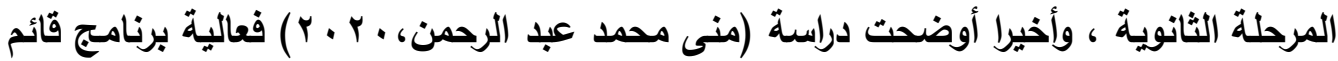
على نظرية الأكاء الناجح في تنمية إدراك الأت الأكاديمي للتلاميذ المتفوقين عقليا ذوى • صعويات التعلم

كذلك أوضحت بعض الدراسات السابقة فاعلية نظرية استخدام نظرية الأكاء الناجح في تدريس المواد الفلسفية وتحقيق بعض نواتج التعلم الخاصة بها ـ فقد أوضحت دراسة (سعاد

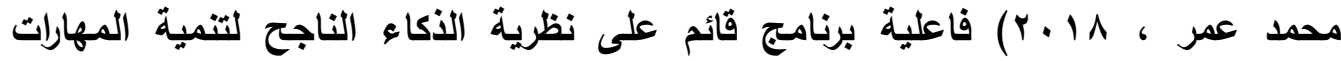
الفلسفية لاى طلاب المرحلة الثانوية ، كذلك أظهرت دراسة (ذكية سعيد عبد الكريم وآخرون

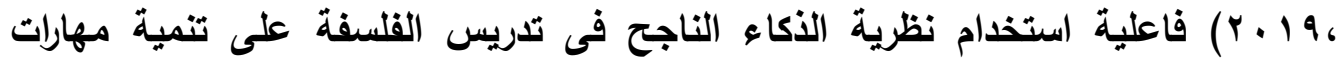
معالجة المعلومات لاى طلاب المرحلة الثانوية ، مما أوضحت دراسة ( أسامة عربي محمد ، 9 ( ب ) فاعلية برنامج قائم على الأكاء الناجح في تدريس علم النفس الطبي على تنمية المسئولية الاجتماعية ومهارة مواجهة الضغوط لاى طالبات المعهد الفني للتمريض،

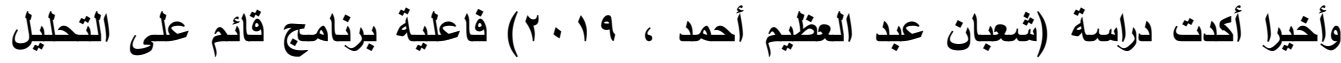
البنائي في ضوء نظرية الأكاء الناجح لتدريس علم النفس على تنمية التفكير التخيلي والمرونة المعرفية لدى طلاب المرحلة الثانوية . وخلاصة القول أن نظرية الأكاء الناجح تعد نظرية شاملة في مجال التعليم والتعلم ، تستتد إلى افتراضات ومبادئ علمية وتريوية ، وتهدف إلى الاستفادة من نقاط القوة والتعويض عن نقاط الضعف لاى الطلاب ، وتسعى إلى التوازن في القدرات الثلاث التحليلية 
والإبداعية وإلعملية ؛ بغيه تحسين عملية التعلم وتحقيق تكاملها لاى المتعلم ، الأمر الذي يبرر أهمية توظيف واستخدام هذه النظرية في التدريس بكل عام ، والمواد الفلسفية بشكل خاص .

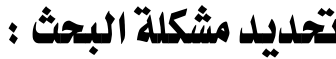

تتحدد مشكلة البحث الحالي في ضعف إتقان وفهم طلاب الصف الأول الثانوي للمفاهيم، وأيضا ضعف مستواهم في مهارات التفكير الايجابي واتجاهاتهم العلمية ؛ وذلك في ظل عدم استخدام المداخل والنماذج التدريسية المناسبة لتنمية هذه الجوانب لاى الطلاب . وفى ضوء ما سبق يسعى البحث الحالي إلى استخدام نموذج مقترح قائم على نظرية الأكاء الناجح في تدريس وحدة مبادئ التفكير العلمي لتنمية المفاهيم والتفكير الايجابي والاتجاهات العلمية لاى طلاب الصف الأول الثانوي ـ وعليه يحاول هذا البحث الإجابة عن السؤال الرئيس التالي : ماتس ما فاعلية استخدام نموذج مقترح قائم على نظرية الذكاء الناجح في تدريس وحدة مبادئ التفكير العلمي على تنمية المفاهيم والتفكير الايجابي والاتجاهات العلمية لدى طلاب الصف

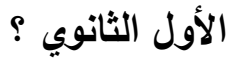

ويتفرغ من هذا السؤال الأسئلة الفرعية الآتية :

1) ما النموذج التدريسي المقترح في ضوء نظرية الأكاء الناجح لتنمية المفاهيم والتفكير

الإيجابي والاتجاهات العلمية لاى طلاب الصف الأول الثانوي ؟

r) ما فاعلية النموذج المقترح في تدريس وحدة مبادئ التفكير العلمي على تنمية

المفاهيم لاى طلاب الصف الأول الثانوي ؟

r) ما فاعلية النموذج المقترح في تدريس وحدة مبادئ التفكير العلمي على تنمية التفكير

الإيجابي لاى طلاب الصف الأول الثانوي ؟

؛) ما فاعلية النموذج المقترح في تدريس وحدة مبادئ التفكير العلمي على تنمية

الاتجاهات العلمية لاى طلاب الصف الأول الثانوي ؟ 


$$
\text { استهرف البحث تحديد ما يلي : }
$$

1) فاعلية النموذج المقترح في تنمية المفاهيم لاى طلاب الصف الأول الثانوي • r) فاعلية النموذج المقترح في تنمية التفكير الإيجابي لاعى طلاب الصف الأول الثانوي.

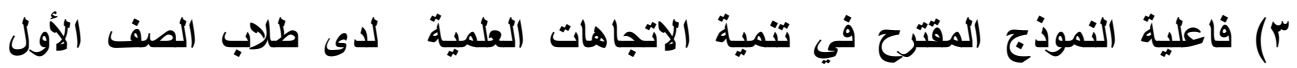

الثانوي.

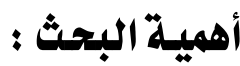

من المتوقع أن يفيد هذا البحث ما يلي :

ا. طلاب الصف الأول الثانوي ، من خلال مساعدتهم على تنمية المفاهيم وإلتفكير

$$
\text { الايجابي والاتجاهات العلمية. }
$$

r. معلمي الفلسفة والمنطق بالمرحلة الثانوية ، من خلال تقديم نموذج إجرائي لكيفية

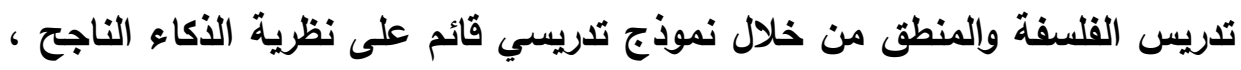
وأيضا تدريبهم على كيفية تنفيذ الإجراءات التدريسية واختيار والأنشطة التعليمية التي تنمى لاى الطلاب المفاهيم والتفكير الإيجابي والاتجاهات العلمية . r. مخططي مناهج القلسفة والمنطق بالمرحلة الثانوية ، من خلال لقت انتباههم إلى الاهي أهمية تضمين الكتب الاراسية بعض الأسئلة التي تحقق الفهم والإتقان للمفاهيم ، وأيضا المعارف والأنشطة التي تنمى مهارات التفكير الإيجابي والاتجاهات العلمية لاى لـ الدي

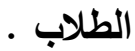
ـ. الباحثين في مجال المنـاهج وطرق التدريس ، من خـلال تقديم مجموعة مـن أدوات

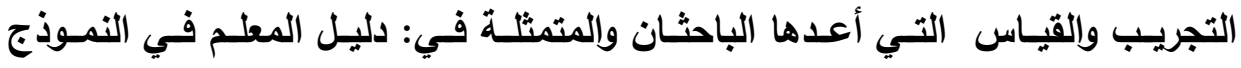
المقترح، كتيـب الطالب فـي النــوذج المقتـرح ، اختبـار المفـاهيم ، اختبـار التفكير الإيجابي ، مقياس الاتجاهات العلمية . 
اقتصر البحث على : (an

1 ـ ـ وحدة مبادئ التفكير العلمي من كتاب مبادئ التفكير القلسفي والعلمي المقرر على طلاب الصف الأول الثانوي" ؛ وذلك لتضمنها عدد من المفاهيم الرئيسية ، واحتوائها على العديد من الخبرات التعليمية التي يمكن من خلالها ممارسة أبعاد التفكير

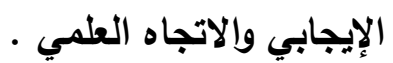

r ـ المفاهيم المتضمنة في وحدة مبادئ التفكير العلمي .

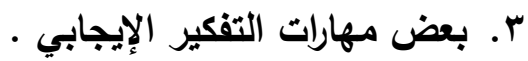

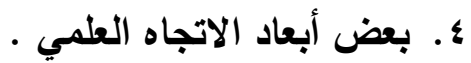
ه. عينة من طلاب الصف الأول الثانوي العام بمحافظة الفيوم .

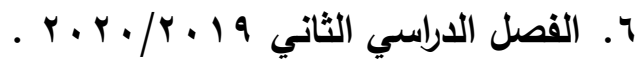

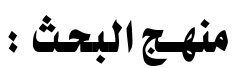

استخدم البحث الحالي المنهج الوصفي التحليلي والمنهج التجريبي ؛ حيث استخدم المنهج الوصفي التحليلي في الإطار النظري للبحث ويناء أدوات البحث، واستخدم المنهج التجريبي في التطبيق الميداني لتجرية البحث. وقد تمثل في تقسيم عينة البحث إلى مجموعتين إحداهما : تجريبية والأخرى ضابطة. مصطاحسات البحث :

تضمن البحث المصطلحات الآتية :

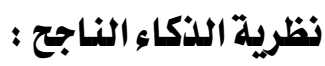

وتعرف في هذا البحث بأنها : مجموعة من المبادئ والتوجهات التي تساعد طلاب الصف الأول الثانوي على إدراك نقاط قوتهم ليستفيدوا منها ، والوعي لنقاط ضعفهم وتصحيحها ، والتوازن في استخدام قدراتهم التحليلية والإبداعية والعملية ، وذلك عند دراستهم لوحدة مبادئ

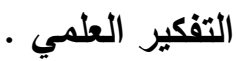

\footnotetext{
كتاب وزارة التربية والتعليم والتعليم الفني : مبادئ التفكير الفلسفي والعلمي لطلاب الصف الأول الثانوي ، طبعة r.r.r./r.194 
( ) النموذج المقترح :

ويعرف في هذا البحث بأنه : نموذج تدريسي قائم على مبادئ وأسس نظرية الذكاء

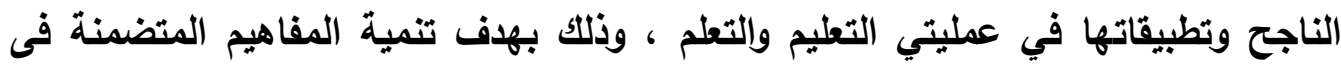
وحدة مبادئ التفكير العلمي ، وأبعاد التفكير الايجابي والاتجاهات العلمية لدى طلاب الصف ولف ولئ الأول الثانوي من خلال دراستهم لوحدة مبادئ التفكير العلمي . : المفاهيـه وتعرف في هذا البحث بأنها: تصور عقلي لمجموعة من الخصائص والسمات المشتركة التي تعبر عن حقائق علمية أو موضوعات وقضايا فلسفية ومنطقية ، وهى تتمثل في المفاهيم المتضمنة في وحدة مبادئ التفكير العلمي من كتاب مبادئ التفكير الفلسفي والعلمي لطلاب الصف الأول الثانوي ، وهى مفاهيم : العلم ، التفكير العلمي ، التفكير الناقد ، التفكير مبن الإبداعي · ويقاس إتقان وتحصيل الطلاب لهذه المفاهيم من خلال درجاتهم على اختبار

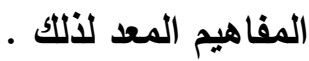

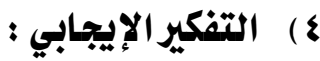
ويعرف في هذا البحث بأنه : ممارسة طلاب الصف الأول الثانوي لمجموعة من العمليات العقلية القائمة على إنتاج وتوليد للأفكار المرتبطة بالتفاؤل والايجابية ، والقدرة على التميز بين الأهداف الواقعية وغير الواقعية ، وضبط الانفعالات ، وتقبل المسئولية الشخصية

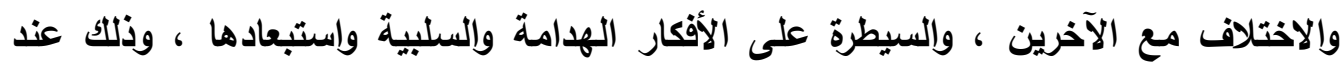

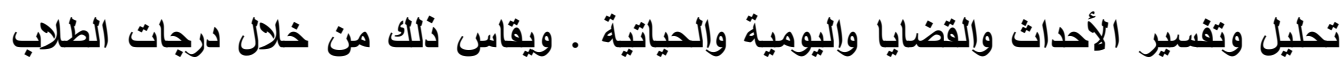

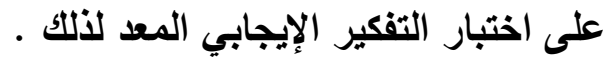

الاتجاهات العلمية : 10 وتعرف في هذا البحث بأنها : مجموعه من السمات العقلية - ذات طابع وجداني والتي تحدد طبيعة تعامل طلاب الصف الأول الثانوي مع الظواهر والأحداث العلمية ، وتتمثل تلكك السمات في حب الاستطلاع، التفتح الذهني وسعة الأفق، الموضوعية ، الأمانة العلمية ، التروي والمثابرة ، وتقاس بالدرجة التي يحصل عليها الطالب فى مقياس الاتجاهات العلمية المعد لذلك . 
أدوات البحث ومواده التجريبية:

تمثلت أدوات البحث ومواده التجريبية فيما يلي:

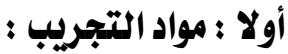

$$
\begin{aligned}
& \text { • • دليل المعلم في النموذج المقترح · (إعداد الباحثان) } \\
& \text { • • كتيب الطالب في النموذج المقترح · (إعداد الباحثّان) }
\end{aligned}
$$

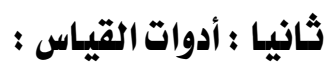

ا اختبار المفاهيم في وحدة " مبادئ التفكير العلمي " (إعداد الباحثًان)

اختبار التفكير الإيجابي. (إعداد الباحثان)

مقياس الاتجاهات العلمية ـ (إعداد الباحثان)

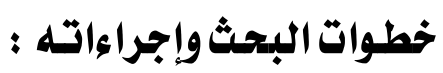

سارت إجراءات هذا البحث وفق الخطوات الآتية :

1) الاطلاع على بعض الأدبيات النظرية والبحوث السابقة المتعلقة بـ :

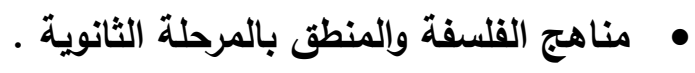

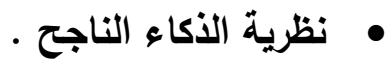

• • طبيعة المفاهيم وأهمية تنميتها داخل مجال المواد القلسفية .

$$
\text { • • • • التفكير الإيجابي . • }
$$

r) إعداد قائمة بمهارات التفكير الإيجابي وعرضها على مجموعة من المحكمين ؛ لتحديد مدى مناسبتها لطلاب الصف الأول الثانوي .

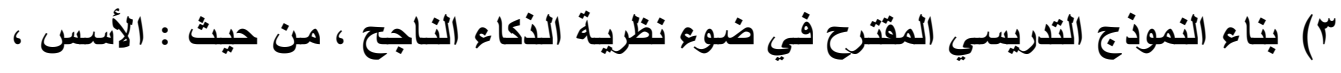

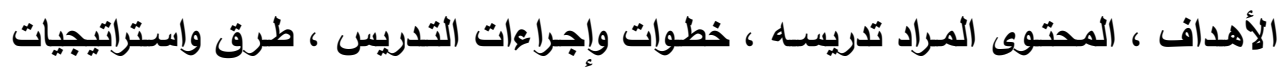

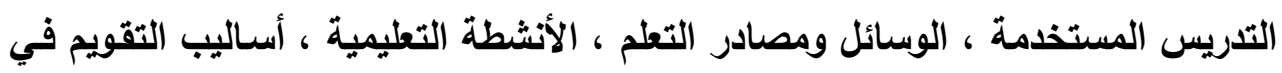

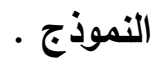

؛) إعداد دليل المعلم والخاص بتدريس وحدة مبادئ التفكير العلمي وفق النموذج المقترح . •) إعداد كتيب الطالب في النموذج المقترح . 
T) إعداد اختبار المفاهيم في وحدة " مبادئ التفكير العلمي " ، وإختبار التفكير الإيجابي ، ومقياس الاتجاهات العلمية، وعرضها على مجموعة من المحكمين، وأيضا ضبطها

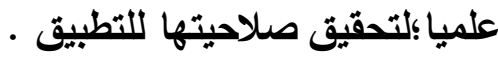
V تحديد عينة البحث وهم بعض طلاب الصف الأول الثانوي - أدبي بمدرسة جمال عبد

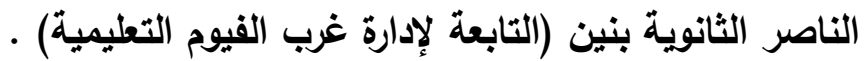
^) تطبيق اختبار المفاهيم ، واختبار التفكير الإيجابي ، ومقياس الاتجاهات العلمية تطبيقا قبلياً على الطلاب عينة البحث. 9) تلريس وحدة " مبادئ التفكير العلمي " وفق النموذج المقترح لطلاب المجموعة التجريبية، وتدريس نفس الوحدة بالطريقة المعتادة لطلاب المجموعة الضابطة . • 1) تطبيق اختبار المفاهيم ، وإختبار التفكير الإيجابي ، ومقياس الاتجاهات العلمية تطبيقا بعدياً على الطلاب عينة البحث. r) 11) رصد النتائج ومعالجتها إحصائيا وتفسيرها.

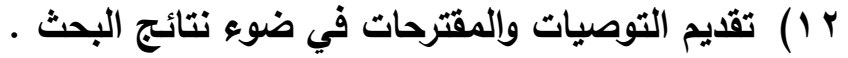
فروض البحث : ماث

حاول البحث اختبار صحة الفروض الإحصائية الآتية : () توجد فروق ذات دلالة إحصائية بين متوسطي درجات طلاب المجموعتين التجريبية والضابطة في التطبيق البعدي لاختبار المفاهيم لصالح المجموعة التجريبية . . r توجد فروق ذات دلالة إحصائية بين متوسطي درجات طلاب المجموعة التجريبية في التطبيقين القبلى والبعدى لاختبار المفاهيم لصالح التطبيق البعدى . r) توجد فروق ذات دلالة إحصائية بين متوسطي درجات طلاب المجموعتين التجريبية والضابطة في التطبيق البعدي لاختبار التفكير الإيجابي لصالح المجموعة التجريبية . §) توجد فروق ذات دلالة إحصائية بين متوسطي درجات طلاب المجموعة التجريبية في التطبيقين القبلى والبعدى لاختبار التفكير الإيجابي لصالح التطبيق البعدى . ه) توجد فروق ذات دلاية إحصائية بين متوسطي درجات طلاب المجموعتين التجريبية والضابطة في التطبيق البعدي لمقياس الاتجاهات العلمية لصالح المجموعة التجريبية . 
T) توجد فروق ذات دلالة إحصائية بين متوسطي درجات طلاب المجموعة التجريبية في

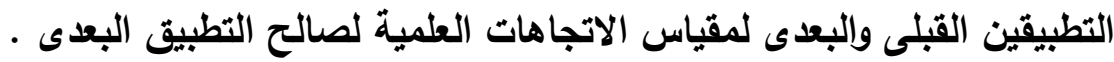

\section{الإطار النظري للبحث}

لما كان البحث الحالي يهرف إلى الكثف عن فاعلية استخدام نموذج مقترح قائم على نظرية الأكاء الناجح في تدريس وحدة "مبادئ التفكير العلمي" لتنمية المفاهيم والتفكير الايجابي والاتجاهات العلمية لاى طلاب الصف الأول الثانوي ، فإن ذلك يتطلب الحديث

بالتفصيل عن المحاور الآتية :

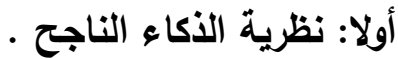

ثانيا : تنمية المفاهيم داخل مجال المواد القلسفية .

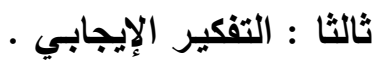

رابعا : الاتجاهات العلمية .

خامسا: دور نظرية الذكاء الناجح في تنمية المفاهيم والتفكير الإيجابي والاتجاهات العلمية من خلال دراسة المواد القلسفية .

أولا : نظرية الذكاء الناجح : ( ) نظرية الذكاء الناجح : النشأة -والمفهوم: نشأت نظرية الأكاء الناجح على يد ستيرنبرغ في ظل تطور نظريات الأكاء وتطبيقاتها \& Cattell والاهتمام بدراسة الفروق الفردية.فقد كاتت البداية من خلال كتابات جالتون وكاتيل Galton مسئول عن معظم القدرات العقلية ، ثم أضاف سبيرمان للعامل العام مجموعة من العوامل الخاصة ـ ويعد ذلك ظهر اتجاه العوامل المتعددة على يد ثورندايك ، ثم تبنى جيلفورد اتجاه يريط بين الأكاء ونواتج العملية العقلية التي يستخدمها الفرد ، ثم ظهر اتجاه الأكاءات المتعددة على يل جاردنر ، ويعد ذلك جاء ستيرنبرج وتحدث عن نظريته في الأكاء الناجح ، والتى نظرت إلى الذكاء باعتباره مجموعة من القدرات التحليلية والإبداعية والعملية المتكاملة . ويالتالي يعد الأكاء الناجح امتداد لنظرية ستيرنبرغ الثلاثية في الذكاء الإنساني ، حيث تخلى

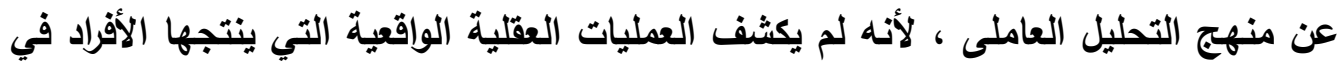

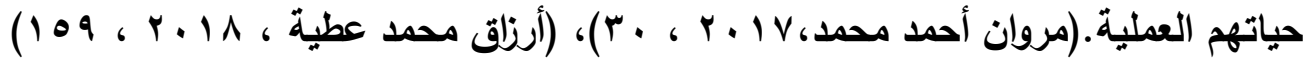


ويشير كل من (Sternberg\&Grigorenko,2004,274-275) أن فشل الطلاب في التعلم بمستوى يضاهي قدرتهم على التعلم قد يرجع لأسباب عديدة منها ، أن تكون الطريقة التي يتم بها تعليم الطلاب وتقييمهم لا تمكنهم من التعلم بطريقة مثلى. ويالتالي جاءت نظرية الأكاء الناجح لمساعدة هؤلاء الطلاب على الوصول إلى إمكاناتهم الكاملة . حيث أن الذكاء الناجح هو استخدام مجموعة متكاملة من القدرات اللازمة لتحقيق النجاح في الحياة، فالطلاب إلاب يحققون النجاح من خلال التعرف على نقاط قوتهم وتحقيق أقصى استفادة منها،وفي نفس الوقت يتعرفون على نقاط ضعفهم ويجدون طرقًا لتصحيحها أو تعويضها. كما أن الطلاب يحتاجون إلى تعلم تصحيح للجوانب التي يكون أداؤهم فيها ضعيفًا ـ ومن ناحية أخرى عليهم

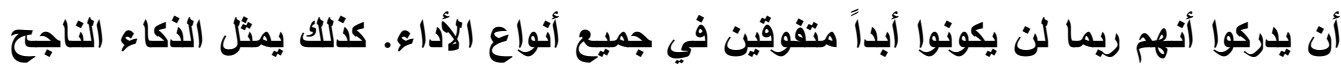
طريقة فعالة لمساعدة الطلاب والمعلمين على التكيف مع البيئات وتتثكيلها واختيارها. فالبنسبة للتكيف مع البيئة، يمكن للمعلم مثلا أن يتكيف مع توقعات مدير المدرسة من خلال التدريس بطريقة يعتقد أن المدير سيطبقها.أما في التثكيل ، فيمكن أن يغير الناس البيئة لتناسبهم. ففي المثال السابق يحاول المعلم إقناع المدير بدعم طريقة جديدة في التدريس تختلف عما اعتاد عليه المدير في الماضي. وأخيرا في الاختيار،يمكن إيجاد بيئة جديدة ،

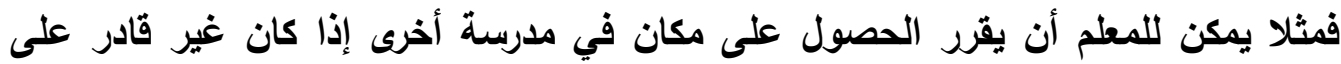
إقتاع مدير المدرسة أن طريقته في التدريس صالحة وستؤدي إلى فوائد للطلاب. ويالتالي فإن الأفراد يحققون الغايات والأهداف السابقة من خلال إيجاد توازن في استخدامهم للقدرات

$$
\text { التحليلية والإبداعية وإلعملية . لماندان }
$$

وتعتمد نظرية الأكاء الناجح على أريعة افتراضات أساسية هي :

1) الأكاء الناجح يعتمد على استخدام مجموعة متكاملة من القدرات للنجاح في الحياة . r الأكاء الإنساني يصعب ممارسته وتنميته بعيدا عن السياق الاجتماعي والثقافي

r) يتوقف تحقيق النجاح على قدرة الفرد على إدراك مواطن القوة لايه والاستفادة منها ، واكتشاف مواطن ضعفه والعمل على معالجتها والتعويض عنها .

؛ ) يقوم الأكاء الناجح على إحاث التوازن بين القدرات التحليلية والإبداعية والعملية . (Sternberg \&Grigorenko,2003,208-2011) , (Sternberg ,2018) 
ويعرف كل من (Sternberg \& Grigorenko,2002,265) الذكاء الناجح بأنه قررة الفرد على تحقيق النجاح في الحياة في ضوء معاييره الذاتية ، ومن خلال سياقه

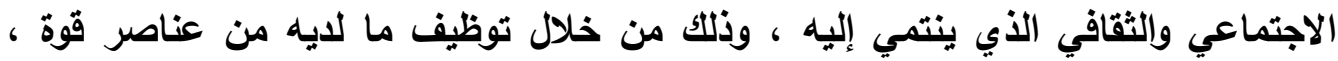

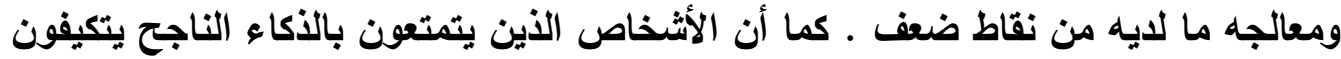
ويشكلون ويختارون البيئات من خلال التوازن في استخدامهم القدرات التحليلية والإبداعية

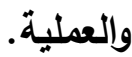

ومن خلال التعريف السابق يمكن تحديد المحكات والمعايير الأساسية للذكاء الناجح في

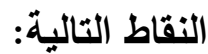
- نظام القدرات التي نحتاجها من أجل النجاح في الحياة هي القدرات التحليلية والإبداعية والعملية . - يحدد النجاح فقط ضمن السياق الاجتماعي والثقافي، ولا يحدث بشكل مجرد، بل حسب المعايير والتوقعات التي يضعها الفرد والآخرين . - قدرة الفرد علي التمييز والاستفادة القصوى من قدراته يتم عن طريق إدراك واستغلال نقاط القوة ومعالجة نقاط الضعف. • قدرة الفرد علي التكيف وتثكيل واختيار البيئة يتم من خلال تكيف التفكير أو السلوك ليتلاءم بشكل أفضل مع البيئة التي يعمل ضمنها ـالئل • يستطيع الفرد النجاح في الحياة من خلال التوازن في استخذام القدرات التحليلية و ولئه الإبداعية والعملية بحيث تثكل نسيجا واحدا .

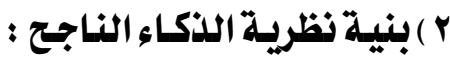
تستند نظرية ستيرنبرغ في الأكاء الإنساني على نظرية معالجة المعلومات ، وتثنتمل على ثلاث نظريات فرعية هي: النظرية التركيبية، والنظرية التجريبية، والنظرية السياقية . وهذه النظريات الفرعية الثلاث تستخدم لتوضيح العالم العقلي الاذخلي للمتعمين، وكيف يستخدمون الذكاء للتفاعل مع بيئتهم. وفيما يلي توضيح لهذه النظريات الفرعية: 
1) النظرية الفرعية التركيبية Componential Subtheory مكونات معالجة المعلومات التي تفعل التمثل الاخلخي للخبرة، وتستخام هذه النظرية كذللك

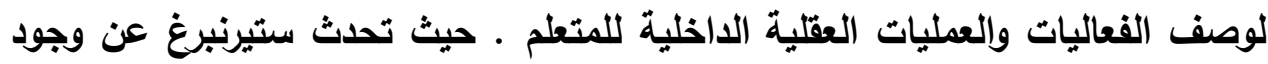
ثلاثة أنواع من العمليات مرتبة من الأعلى ، هي كالتالي : - عمليات ما وراء المعرفة : وتثمل الوعي بوجود مشكلة وتحديد طبيعتها واتخاذ القرار بثأن إجراءات حلها ، وتقييم الحل بعد تجريبه . - مكونات الأداء : وهو العنصر التنفيذي لتعليمات ما وراء المعرفة ، ويتضمن عمليات الأداء

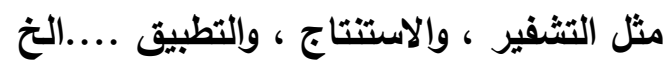
- مكونات اكتساب المعرفة : وتثثمل عمليات الترميز الانتقائي ، والدمج الانتقائي ، والتمييز

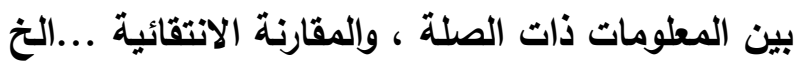

r) النظرية الفرعية التجريبية :Experiential Subtheory : حيث أن المهمات البيئية التي تطبق فيها مكونات معالجة المعلومات تختلف في كونها مألوفة للمتعلم حسب النظرية التجريبية، ويعتق أن أفضل طريقة لقياس الذكاء هي المهمات التي تتضمن

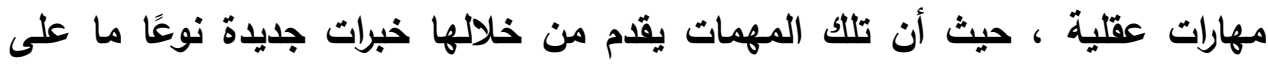
المتعلم. r) النظرية الفرعية السياقية (البيئية) Contextual Subtheory : وتعكس النظرية

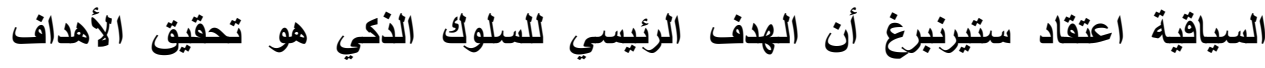

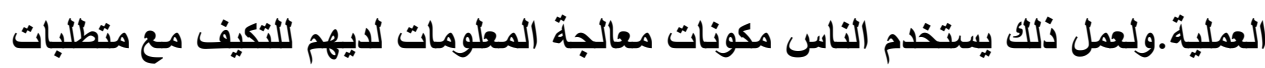

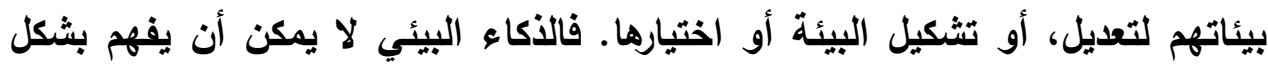
كامل خارج السياق الاجتماعي الثقافي.

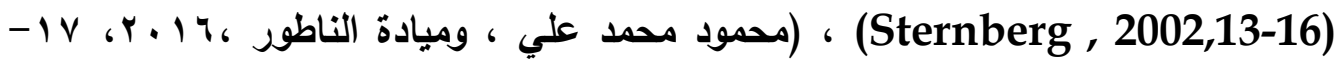

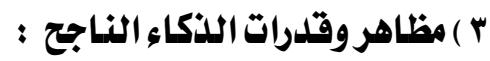
طبقاً للنظرية المقترحة للأكاء الإنساني (نظرية الذكاء الثثلاثي) لستيرنبيرج وتطورها ، النياء هناك مجموعة مشتركة من العمليات تقع تحت مسمى الأكاء ـ ويفترض ستيرنبيرج أن هذه النهاء

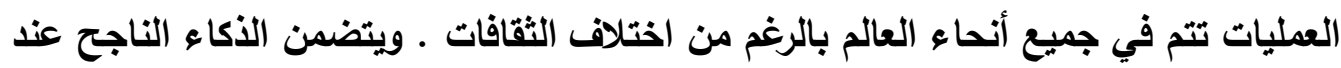


ستيرنبيرج ثلاثة مظاهر أو قرات أساسية هي كالتالي: -(Sternberg,2005,191)

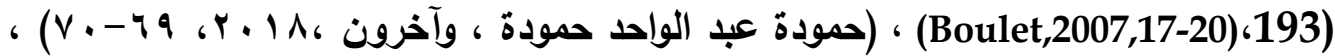

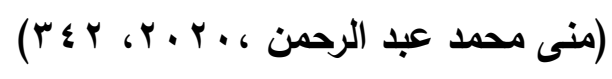

أ) الذكاء التحليلي Analytical intelligence : وهو العملية التي يسعى من خلالها القرد إلى حل المشاكل المألوفة باستخدام استراتيجيات تعالج عناصر المشكلة أو العلاقات بين العناصر • ويتضمن الذكاء التحليلي المهارات التالية: التحليل، والمقارنة، والتصنيف، والتقييزي، والتفسير ، والحكم، والنقا.

ب) الذكاء الإبلاعي Creative intelligence : ويعني قدرة الفرد علي تسخير مهاراته في

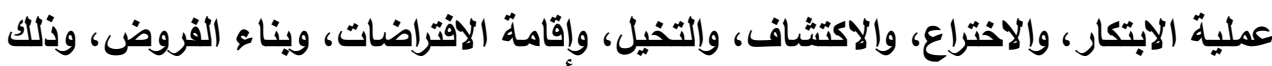

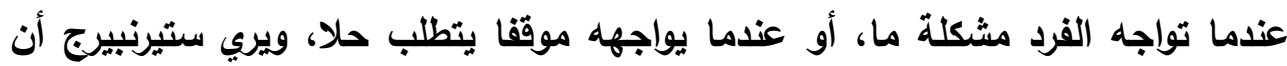

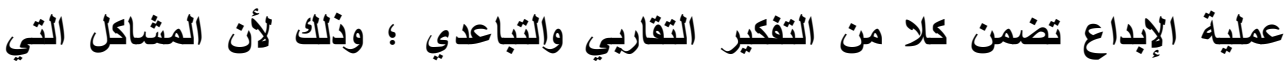
يتعرض لها الفرد وتتطلب حلولا تحتوي علي نوعي التفكير التقاربي والتباعدي وليس نوعا لهاعي واحدا فقط . ج) الذكاء العملي التطبيقي Practical intelligence ويغني قدرة الفرد علي تضمين كل مهاراته وتسخيرها بصورة عملية، وذلك في سياق عالمه الواقعي (الحقيقي) ، بحيث

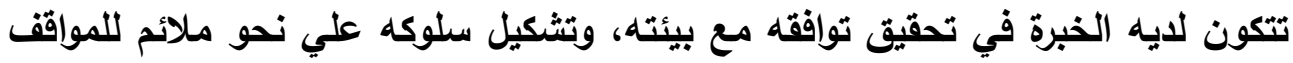

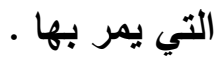
والذكاءات الثلاثة تتاخل معا فالذكاء التحليلي يرى العلاقات والأنماط بين معلومات المشكلة، ويمارس عمليات التحليل والتقييم والحكم عليها ، بينما ينتج الذكاء الإبداعي الحلول

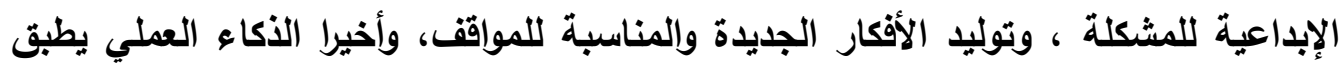

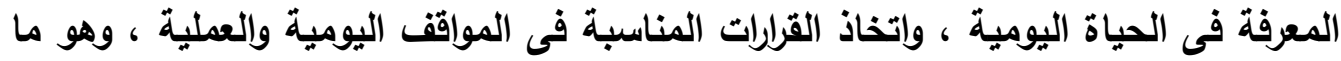
يعنى التوازن بين الذكاءات الثلاث.

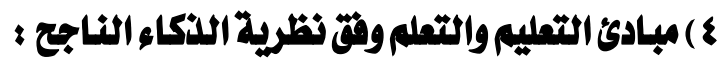
تتضمن نظرية الناجح العايد من الأسس والمبادئ التي يمكن استخدامها في عمليتي التعليم والتطلم ، أهمها ما يلي: (Baum \& Bird,2010,399-401) ، (عبد المنعم أحمد

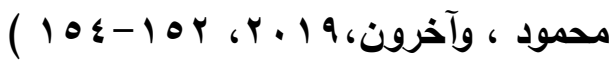


ليس جميع المتعلمين لايهم قدرة عالية على التذكر ، فالكثير من الطلاب لايهم القدرة على التعلم ، ولكنهم يفشلون عند محاولة حفظ أو استدعاء مجموعة من الحقائق . هجب أن يسعى المعلم من خلال التريس إلى تقييم وتنمية ذاكرة الطلاب ، بحيث لا يتوقف عند حد المخزون السابق في الأكرة ، بل يستغل هذا المخزون في تطوير خبرات جديدة .

• الهدف من التعلم هو اكتساب المعرفة بشكل جيد ومرن ، بحيث يمكن استرجاعها بسهولة . بهوب

لابد أن تتضمن العملية التعليمية التدريس التحليلي ، والتفكير العملي ، والتفكير الإبداعي ، وأيضا التعلم من أجل الذاكرة ، وأكل منهم دور في العملية التعليمية ـ فقدرة الطالب على استخدام قدراته التحليلية والإبداعية والعملية يمكنه من ترميز المعلومات بطرق متعددة وتنظيمها بمرونة مما يمكنه من سهولة الوصول إليها ، واسترجاعها وقت لهن الحاجة إليها ـ هنبفي أن يشتمل التقييم على تقييم تحليلي ، وتقييم إبداعي ، وتقييم عملي، وكذلك تقييم للاكرة . التعلم الأمثل يساعد الطالب على الاستفادة القصوى من نقاط القوة لايه،مما يساعد على القي تحسين الأداء الأكاديمي بشكل كبير. التفكير الإبداعي بالنسبة للمتعلم هو قرار بالتفكير في الأثياء بطريقة مختلفة،ويهدف إلى إعادة تعريف المشكلة بلالا من مجرد قبولها،حيث يكون لاى المتعلم استعداد للمخاطرة الفكرية،ويتمتع بالقدرة على إقناع الآخرين بأفكاره،والثقة في قدرته على على إنتاج أفكار إبداعية . - ماطية التفكير العملي هو تعلم الطلاب كيفية تبنى بعض المواقف في حياتهم ، وكيفية تطوير

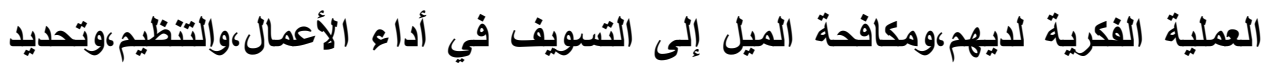
الطرق المثلى للتعلم. 0 ) أهمية استخلام نظرية الذكاء الناجح في التلدريس : أظهرت العديد من الأدبيات والدراسات السابقة أهمية التريس وفق نظرية الأكاء الناجح لكل من الطلاب والمعلمين ، ويمكن إيجاز تلك الأهمية في النقاط التالية: 
، (هلى مصطفى محمد (Hunt ,2008,509-510)، (Sternberg,2002,383-384)

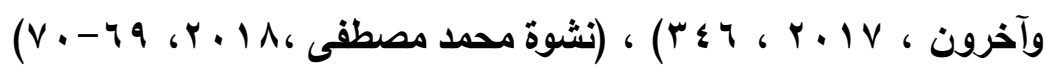

• تعمل نظرية الذكاء الناجح على تحقيق الانسجام بين عملية الكثف، وطرق التدريس ،

$$
\text { وعملية التقييم . }
$$

• تعزيز القرة على الاحتفاظ بالمادة المتعلمة ، فمن خلال هذه النظرية يمكن استخدام

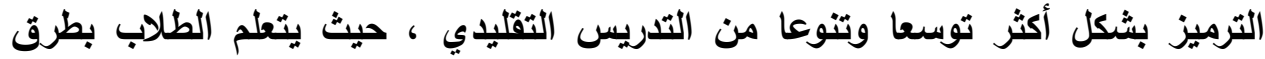

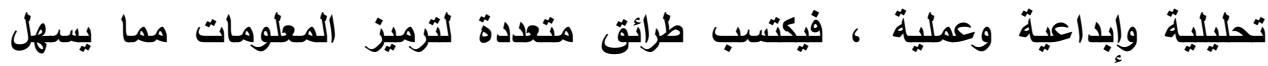
استرجاعها.

• تخاطب عدد أكبر من الطلاب ، وذلك لأن هناك بعض الطلاب الذين لا تعجبهم طريقة محددة في التدريس ، ولكن من خلال استخدام الذكاء الناجح يصل المعلم إلى عدد كبير

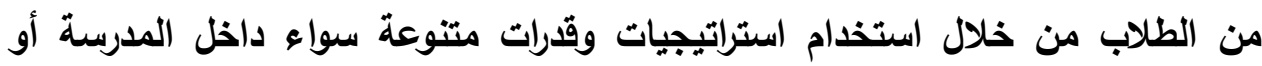

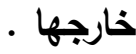
مراعاة الفروق الفردية بين الطلاب ، وذلك من خلال توفير بيئة مدعمة يجد فيها الطلاب الأنماط المختلفة من قدراتهم . • قدم ستيرنبرج من خلال نظريته العديد من الأدلة التجريبية على أن التدريس من خلال الأكاء الناجح يزيد من مستوى التحصيل المعرفي لاى الطلاب فى مختلف المراحل الداساسة . • تساعد على الإفادة من نقاط القوة لاى الطلاب ـ حيث أن الطالب من خلال هذه النظرية يمكنه ممارسة وتعزيز قدراته ومواهبه في المجالات المختلفة دون التركيز على قدرات معينة كما يوجد في الفصول التقليدية . • تستخدم هذه النظرية بعض الإجراءات التي تضمن قيام المعلم بالتدريس الفعال ،

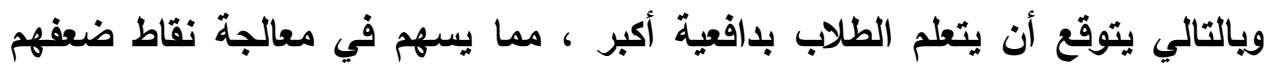
والتعويض عنها . ملاعمتها لجميع الفئات ومناسبته لكل المستويات . حيث يمكن تطبيق نظرية الذكاء

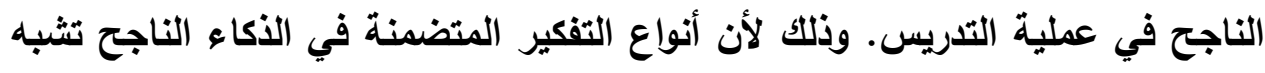
إلى حد كبير أنواع التفكير المطلوية للعمل والتعايش في الحياة اليومية. 
وتأكيدا للأهمية السابقة ، فقد أكلات بعض الدراسات السابقة فاعلية نظرية الاكاء الناجح في عمليتي التعليم والتعلم ، ومن هذه الدراسات :

• دراسة (2002, Wendy \& et.al): والتى أوضحت أن تصميم برامج قائمة على تطبيقات الأكاء العملي - كأحد قدرات الذكاء الناجح- يدعم قدرات ما وراء المعرفة وإلتحصيل لدى طلاب المرحلة المتوسطة .

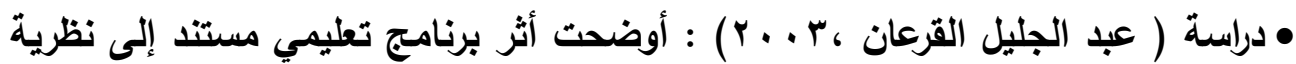
ستيرنبرغ الثلاثية فى تحسين مستوى اتخاذ القرار لاي طلبة الصف الأول الثانوي (أدبي /علمي)

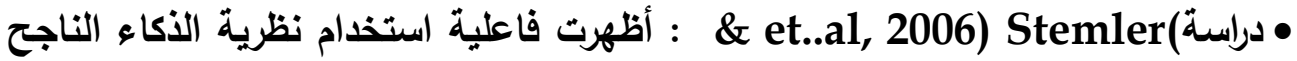
فى تطوير اختبارات متقدمة لقياس القدرات التحليلية والإبداعية والعملية لاى طلاب المرحلة الثانوية فى مادة الإحصاء وعلم النفس.

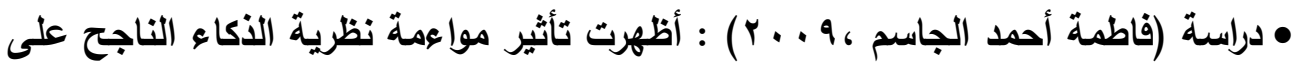
القدرات التحليلية والإبداعية والعملية لمنهج الصف الثالث الابتدائي . • دراسة (2014, Sternberg \&et.al) : والتى استخدمت تطبيقات نظرية الأكاء الناجح فى تدريس فنون اللغة والرياضيات والعلوم.

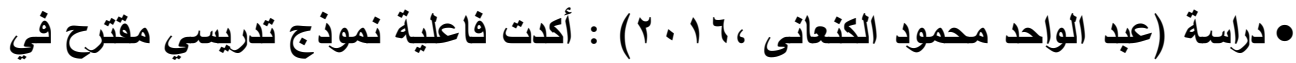
ضوء نظرية الذكاء الناجح في تحصيل طلاب الصف الرابع العلمي من مادة الرياضيات

$$
\text { وتتمية تفكيرهم الإبداعي · مدرية }
$$

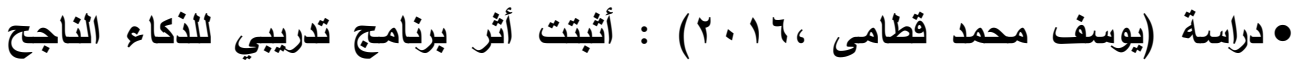
المستتد إلى نموذج ستيرنبرج ومهارات التفكير فوق المعرفي في تحسين درجة ممارسة التفكير الناقد لاى طلبة الصف السادس الاساسى في.

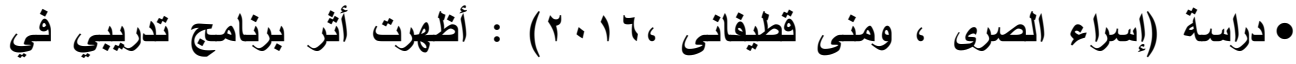
الرياضيات مستند إلى نظرية الذكاء الناجح في تنمية مهارة حل المشكلات للطلبة الموهوبين في رياض الأطفال . الميات • دراسة (عذاري جعفر حسن ، V • V) : استخدمت تحليل بروفايل زمن الرجع ونوعية المهام المستندة إلي نظرية الأكاء الناجح لدي الموهويين والمتفوقين والمبدعين . 


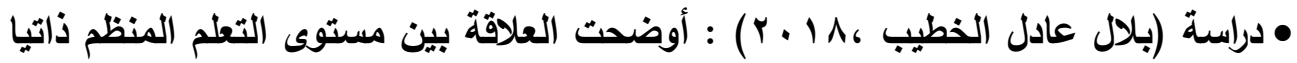
والذكاء الناجح لاى الطلبة الموهوبين . ثانيا : تنمية المفاهيم داخل مجال المواد الفلسفية :

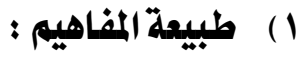
المفهوم هو فكرة مجردة أو تعميم ناتج عن خبرة ما، أو نتيجة لتحويل الأفكار القائمة،

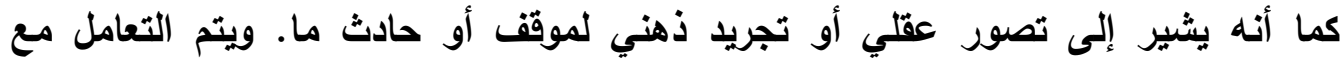
المفاهيم في معظم التخصصات سواء بشكل صريح كما هو الحال في علم النفس والفلسفة وغيرها، أو ضمنا كما هو الحال في الرياضيات. وتقوم المفاهيم كأحد مستويات المعرفة بعدة فئات

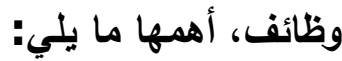
- تبسيط العالم الواقعي من أجل تواصل وتفاهم يتصف بالكفاية .

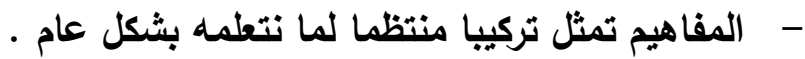

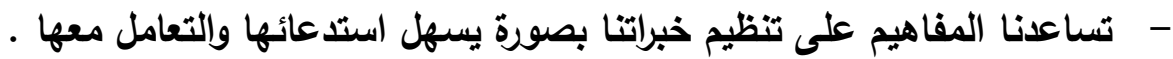

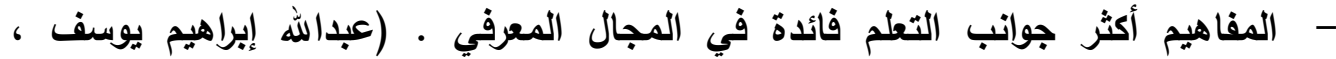
$(r+10,1)$ وتعرف المفاهيم العلمية بأنها صياغة مجردة للخصائص المشتركة بين مجموعة من

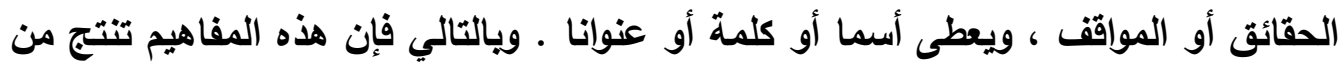
التفكير المجرد ، وتظهر العلاقات المتبادلة بين الحقائق العلمية ـ (منى مصطفى كمال ، (rq 4.49 كما تعرف المفاهيم المنطقية بأنها " تصور عقلي لمجموعة من السمات والصفات وإلخصائص يتم التعبير عنها بكلمات أو رموز أو مصطلحات تثثير إلى مجموعة من التهات الموضوعات والقضايا المنطقية مثل :المنطق والاستدلال، قوانين الفكر الأساسية، الحدود

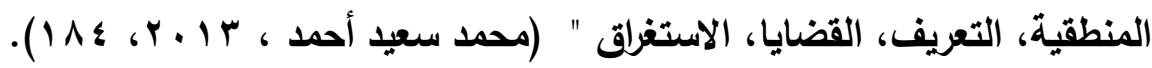

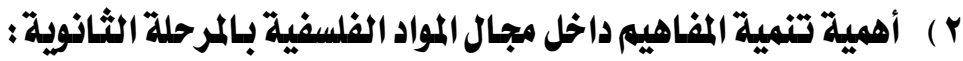

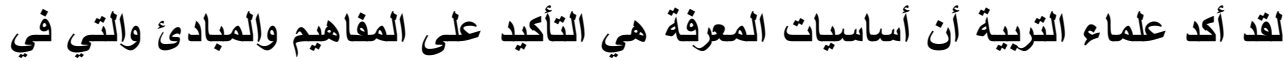
ضوئها يمكن فهم العديد من الحقائق لمجال معين ، حيث تمثل المفاهيم أحد أهم مستويات البناء المعرفي التي تبنى عليها باقي المستويات من مبادئ وتعميمات، وقوانين، ونظريات 
ومن أهم نواتج التعلم التي يمكن من خلالها تنظيم المعرفة العلمية لاى المتعلم .(أسماء

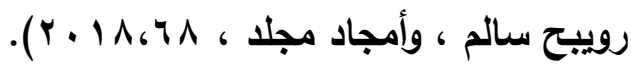

وفى مجال تدريس المواد القلنفية بالمرحلة الثانوية توضح (آمال جمعة عبد الفتاح ،

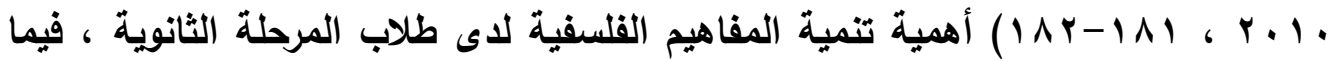
:إلي :

تعد المفاهيم القلسفية واحدة من أهم جواتب التعلم في القلسفة .

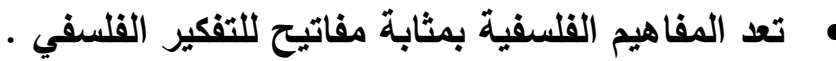
تنمى لاى الطلاب مجموعة من القدرات مثل التحليل والتفسير وإدراك العلاقات والمقارنة وإلتصنيف .

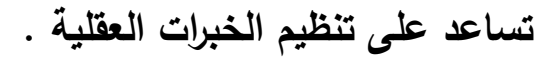
• • تساعد في تحقيق التعلم ذي المعنى • • تساعد على ريط الطالب بالبيئة الاجتماعية التي يعيش فيها .

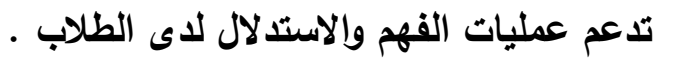

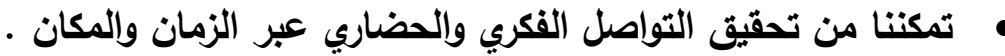
تتصف المفاهيم القلسفية بالشمولية ومن ثم تعطى صورة كلية تساهم في توضيح المشكلات الفلسفية وتكسب الطالب دقة التعبير وتوصيل أفكاره الفلسفية بسهولة ويسر كما أن تعليم وتعلم المفاهيم المنطقية يعد من أهم أهداف تدريس القلسفة والمنطق فى المرحلة الثانوية ـ ويمكن إيجاز تلك الأهمية فى النقاط التالية : • تقع قضية تنمية المفاهيم المنطقية في مقدمة المهام التي يضطلع بها تعليم التقلسف ، وتتزايد الحاجة إلى ذلك بالنظر إلى العديد من الاعتبارات التي يتمثل أهمها فى أن تدريب الطلاب على كيفية إدراك وتكوين المفاهيم المنطقية الأساسية من أهم أهداف تدريس المنطق بالمرحلة الثانوية ، كما أن العناية بتوضيح معاني الألفاظ والمصطلحات القلسفية والمنطقية يعد من المبادئ الأساسية التى يتعين مراعاتها في برامج تدريس القلسفة ، وأخيرا مواكبة أحلث الاتجاهات التربوية العالمية التي تنادي بتنمية المفاهيم

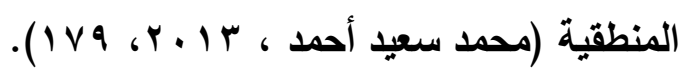


• تأتى أهمية تنمية المفاهيم المنطقية من الأهمية الخاصة لاراسة مادة المنطق ، حيث أن دراسة المنطق من الدراسات الشيقة التي تثير إعجاب كثير من الدارسين ، ولكن

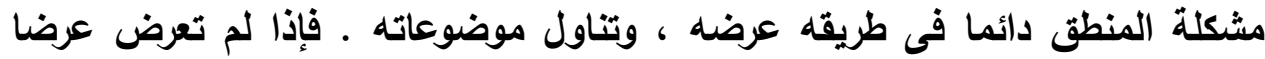
يستحوذ على انتباه الدارس من خلال الأمثلة المنتقاة بشكل واع ، وتسلسل الأفكار بطريقه سليمة ، وتوضح وفهم مفاهيمه ، فريما نفر منه الدارس ولم يستطيع استيعاب موضوعاته ، ويالتالي لا يستفيذ من الفوائد التى يمكن أن يجنيها من معرفته بهذا العلم.

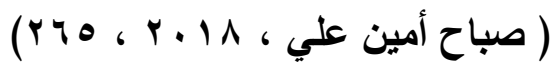
• ما أوضحته بعض الدراسات السابقة من وجود تصورات خاطئة عن المفاهيم بشكل عام

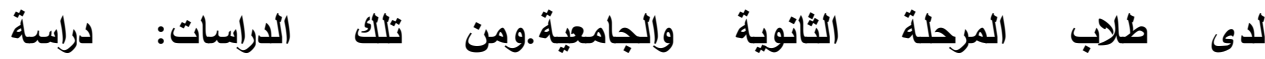
(Nelson Burton and Others (Thompson\&Logue:2006 (2007) ، ودراســة (Hamza \&Wickman,2008) ، ودراسة (Stojanovska) (G Others:2012) هذه التصورات الخاطئة ، والتى تأخذ عده أثكال منها : الخلط بين المفاهيم ، وسوء فهم بعض المفاهيم ، وتقليم تفسيرات غير صحيحة لبعض المفاهيم ، وتقديم تعريفات ناقصة لبعض المفاهيم المنطقية يؤثر على تعلم وتنمية المفاهيم بشكل صحيح وحقيقي لاى الطلاب.ومن هنا تتضح أهمية تنمية المفاهيم لدى الطلاب فى المرحلة الثانوية حتى يتم معالجة وتصحيح هذه التصورات الخاطئة . كذلك أوضحت بعض الأدبيات أهمية تنمية المفاهيم العلمية لاى الطلاب ـ والتى يمكن

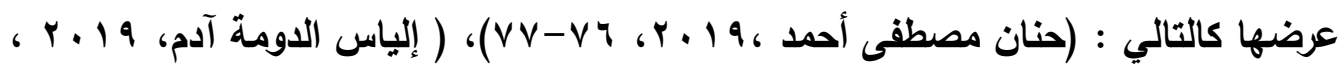

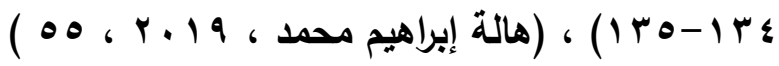
• تسهم فى تفسير الظواهر الطبيعية والقيام بالاستجابات المناسبة وتسهيل دراسة الخبرات بريط الأحداث والظواهر والأشياء يبعضها البعض .

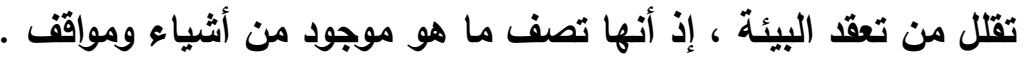

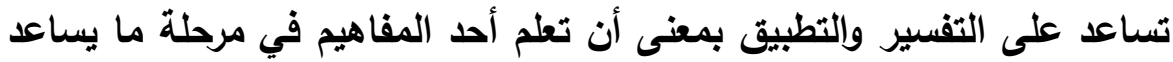

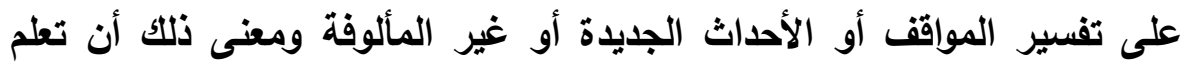
المفاهيم العلمية يساعد على انتقال أثر التعلم. 
• تعد المفاهيم أساس بناء التفكير ، فهى تساعد المتعلم على التفكير بشكل مجرد ، وتفسير الخبرات بربط الأحداث وإلظواهر والأشياء ببضعها البعض . تساعد على التوجيه والتتبؤ والتخطيط لأي نشاط ، فتقلل الحاجة إلى إعادة التعلم عند مواجهة أي موقف جديا . تعد المفاهيم بمثابة الوسائل التى تعرف بها الأشياء الموجودة فى البيئة . تساعد فى حل بعض صعويات التعلم من خلال البناء الهرمى لها ، حيث يتم الانتقال من مفهوم لآخر أو من مرحلة لأخرى .

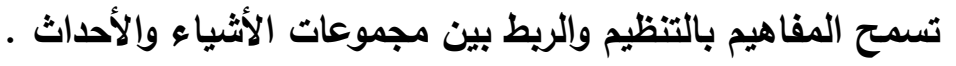
تعد المفاهيم العلمية وسيلة اتصال وتفاهم بين الأفراد ، وتساعد على تقدير المتعلم للمشاكل المحلية والعالمية . تزيد من القدرة على استخدام المعلومات فى مواقف حل المشكلات . يعتمد بناء المناهج على المفاهيم العلمية وترابطها وتكوينها ونموها فى المراحل ميل التعليمية المختلفة . المفاهيم أكثر ثباتا واستقرارا من الحقائق ، وتلعب دورا رئيسيا فى اكتساب المعرفة من خلال المعلومات ذات المعنى • تدريس المفاهيم العلمية سيمننا من إبراز الترابط والتكامل بين فروع العلم

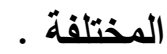

\section{ثالثا : التفكيـــر الإيجابــي: ( ) مفهوم التفكير الإيجابي:} يندرج التفكير الايجابي ضمن مفاهيم علم النفس الايجابي ، وقد انبثق من عدة مفاهيم مختلفة ، منها التفكير البنائي الأي قدمته النظرية البنائية ، والذي يركز على اكتساب الفرد

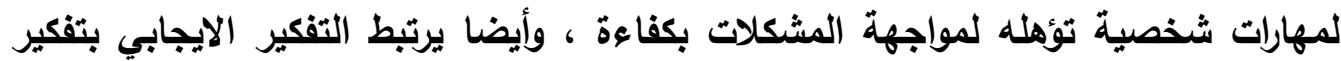

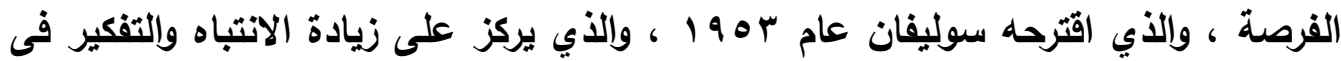
النجاح فى حل المشكلات ، والتفكير فى العوامل التي تؤدى إلى تعديد مشكلة ما ، والبعد عن التركيز على جوانب الفشل ، وذلك استنادا إلى أن المتميزين فى تفكير الفرصة لديهم اعتقادات وقناعات راسخة يوجهون بها تفكيرهم ، ومن هذه الاعتقادات المحاولة من أجل 
النجاح وليس المحاولة والخطأ ـ (سلوى عبد السلام عبد الغنى وسحر السيد

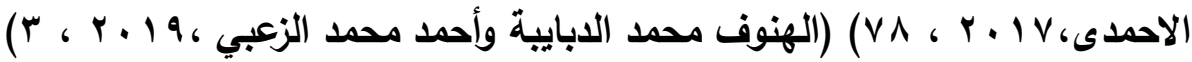

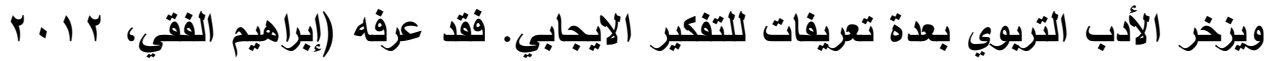
، 0 ) بأنه التفاؤل بكل ما تحمل هذه الكلمة من معاني والسعي نحو الأفضل ، واستغلال

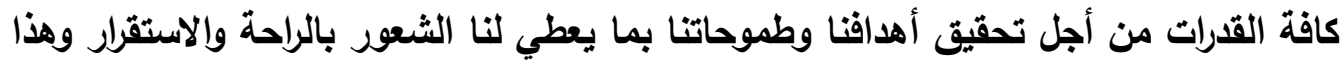

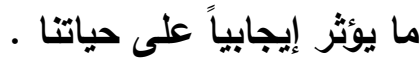

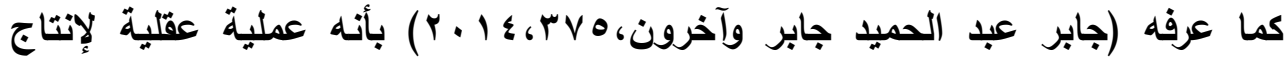
وخلق للأفكار التي ترتبط بالابتكار والسيطرة الآلية على أخطاء التفكير الهامة التهة وتقويمها وتوجيهها بطريقة فعالة تضفي إيجابية على الحياة الشخصية أو العطلية، والسماح للأفكار العقلية والإيجابية بأن تؤدي إلى التوسع والنمو والنجاح ، وتوقع نتائج النجاح . وأيضا يعرف (Denise,2017,8-9) التفكير الايجابي بأنه "عملية معرفية تبعث على الأمل ، وتساعد في حل المشكلات ، وتسمح للفرد بالنظر إلى الأحداث السلبية ، والتفاؤل

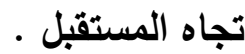
ومن خلال التعريفات السابقة يتضح أن : - التفكير الايجابي يتضمن مجموعة المهارات التي يمكن تعلمها وإتقانها ، بحيث تكون

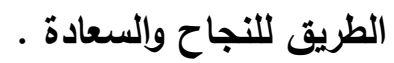
- التفكير الايجابي يعد تهيؤ عقلي نحو إيجاد الحلول للمشكلات والمواقف بنظرة ايجابية متفائلة . مائل - التفكير الايجابي يعد نظام تدريب للعقل البشرى لتغيير الواقع نحو الأفضل.

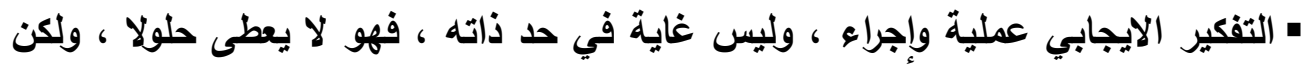
يعطى فرصا لإيجاد الحلول ، والتفكير فيما هو ممكن .

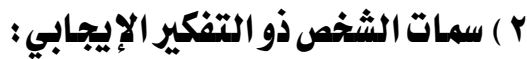
تناولت بعض الأدبيات التربوية سمات الثخص الثيد ذو التفكير الايجابي من خلال

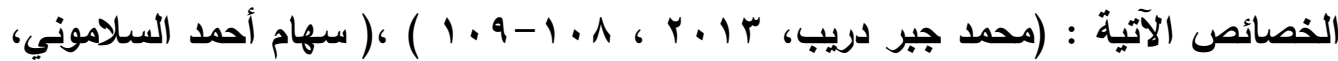


• قادر على الحوار والمناقشة العلمية، وتكون نتائج مناقشته وحواراته مثمرة ومفيدة بالنسبة له وللآخرين.

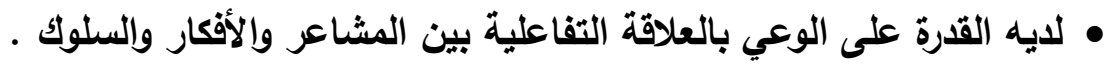
• ذو لغة ومفردات تتصف بالمرونة قابلة للأخذ والعطاء. • لله القدرة على اختيار كلامه بحيث لا يستهزأ ولا يتهم بالآخرين، وله القدرة في تقديم النقّ وإلملاحظات للآخرين بشكل بناء ومفيد. • يمتلك الفكر المستتير وله القدرة على إبداء الرأي واحترام آراء الآخرين، ويكون حديثه مناسبا للموقف ومقتع للآخرين. • يبحث عن المعلومات والمعرفة الجديدة سواء أكان موافقا أو معارضا لها، كما يتميز بإعطائه الحق للآخرين. • يميل إلى إعطاء تصور طبيعي وواقعي عن ذاته أمام الآخرين. • يعطي حلول ناجعة ومبتكرة وجديدة للمشكلات التي يصادفهاءولذلك يعتبر من الأفراد المبدعين.

• لا يضع نفسه في مواقف حرجة أثناء المناقشات لأنه يمتلك الثقافة والمعرفة والمرونة الفكرية التي تساعده على تجنب مثل هذه المواقف. • ينظر إلى نفسه بتواضع ويقدم نفسه للآخرين بشفافية، ويدرك أن المثالية والكمال ليست من صفات البشر. • الأكثر تكيفا مع نفسه وأفكاره ومشاعره ويبحث عن الأفكار قبل أن يحصل على الأحداث.

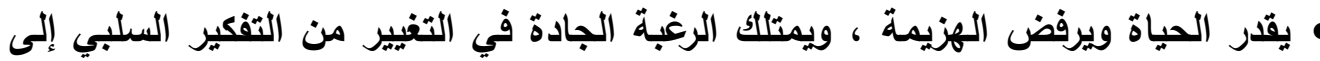

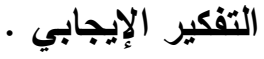

• يركز على النجاحات ويستخدم الألفاظ التي تدعم هذا النجاح في أبسط صوره. • يستخدم أسلوب التحدث مع الذات الأي يجعله متمكنا من مراقبة وتقويم أفكاره الداخلية وقناعاته لتوقع النجاح في حل المشكلات التي تصادفه. • لايه القدرة على الاسترخاء الطبيعي والتحكم في التغيرات التي تؤثر على ضبط انفعالاته . • يتميز بانخفاض مستويات القلق والخوف من مواجهة المشكلات الضاغطة مثل مواقف التنافس ومواجهة الجمهور أو مواقف الاختبار. 
r ا أهمية تنمية مهارات التفكير الإيجابي للدى طلاب المر حلة الثانوية :

أظهرت العديد من الأدبيات التريوية تنمية مهارات التفكير الايجابي لاى طلاب المرحلة الثانوية ـ ويمكن إيضاح ذلك فى عدة نقاط كالتالي : • يساعد الطالب على التكيف على نحو أفضل مع الموقف ، ويزيد من قدرته على حل المشكلات الحياتية التي تواجهه . • يشعر الطالب بالتفاؤل نتيجة لتوقع النتائج الايجابية فى مختلف المواقف والأحداث ،

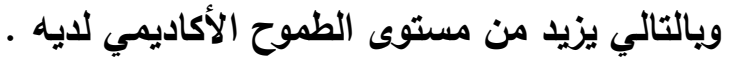
• تشجيع الطالب على إقرار طريقة تفكيره ، فإذا اختار أن يفكر بطريقة ايجابية ، فإنه

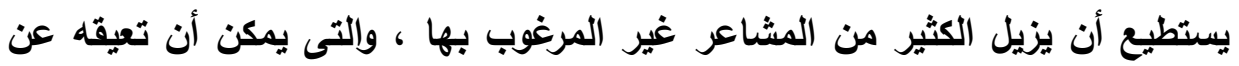
تحقيق الكثير من الأهداف . • أثبتت الدراسات وجود علاقة بين الإبداع والمشاعر الايجابية ، حيث أن الطلاب الذين يتمتعوا بالايجابية تكون لايهم ميول إبداعية . • يرتبط الاتجاه العقلي الإيجابي ارتباطًا وثيقًا بنجاح الطالب في كل مجال من مجالات الحياة. • أوضحت بعض الدراسات أن التفكير الإيجابي يسهم في علاج التأخر الدراسي لاى المتعلمين. • التفكير الإيجابي هو تفكير بناء توالدي، وتصدر منه المقترحات الملموسة والعملية

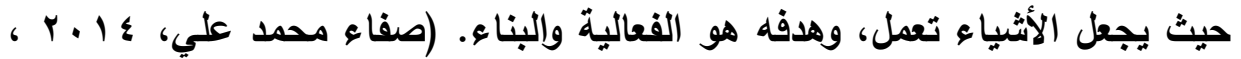

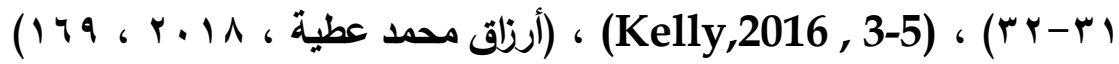

ع أبعاد ومهارات التقكير الإيجابي؛ أظهرت لنا الأدبيات التريوية والدراسات السابقة عدة محاولات لتحديد أبعاد ومهارات

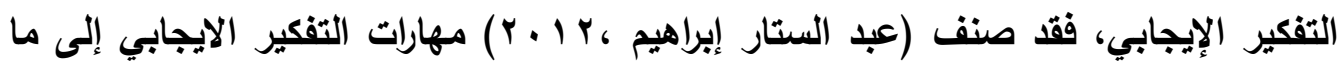
• التوقعات الإيجابية والتقاؤل . • الضبط الانفعالي والتحكم فى العمليات العقلية العليا . • حب التعلم والتقتح المعرفي الصحي . 


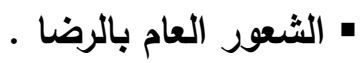

• التقبل الايجابي للاختلاف عن الآخرين .

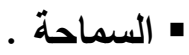

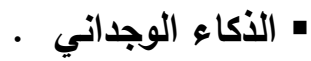

- تقبل غير مشروط للأات .

• تقبل المسئولية الثخصية .

• المجازفة الإيجابية .

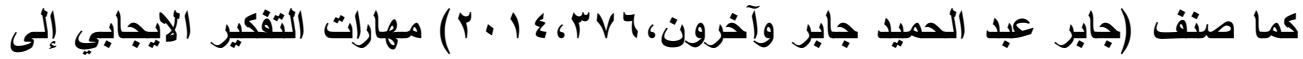

ما يلي:

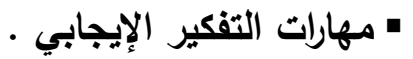

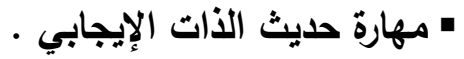

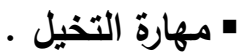

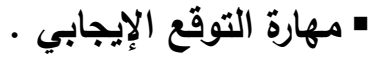

• مهارة حل المشكلات العياتية .

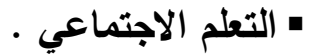

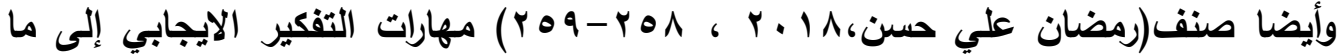

• حليث الأتات الايجابي .

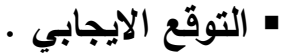

• إدراك الذات الايجابي •

• التخيل الايجابي •

• حل المشكلات .

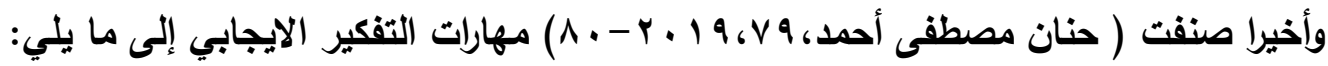

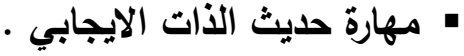

• مهارة التخيل .

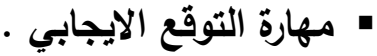


• مهارة حل المشكلات الحياتية .

وفى ضوء التصنيفات السابقة وغيرها تم إعداد قائمة بأبعاد ومهارات التفكير الايجابي المناسبة لطلاب الصف الأول الثانوي موعي

\section{•) طرق وتقتيات تكوين العقلية الإيجابية :}

هناك عده طرق لتطوير توجه عقلي إيجابي لاى الفرد ، تحددها ( إيمان حسنين

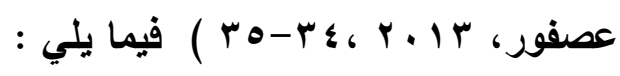

• التركيز الإيجابي على الحاضر: أي عدم الاستغرلق في مشكلات الماضي حتى لا تصبح أكثر مما هي عليه بالفعل. • استخدام اللغة الإيجابية: أي أن يذكر الإنسان نفسه دائماً بأن أفكاره تتشكل من كلماته، ولذا يجب تجنب استخدام اللغة السلبية، ويقول المفكر "ويلي نيلسون Willie Nelson

$$
\text { التنائج الإيجابية." الإئ }
$$

• تقبل الأمور التي لا يمكن تغييرها: أي تقبل الأمور التي لم تسر بالطريقة التي خُطط لها، وخاصة الأمور التي تكون خارج السيطرة، وأكبر من قدرات الفرد، وتجنب إهدار الطاقة الأتية على المشاعر السلبية الهادمة. • التفاعل مع الآخرين والتواصل معهم: الالتقاء بالآخرين يجعل الفرد في حالة أفضل، وخاصة إذا تخلل الضحك هذه اللقاءات، لأنه يقلل من حدة الإجهاد والتوتز والقلق،

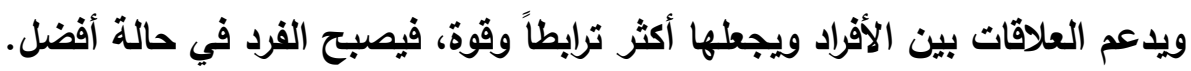

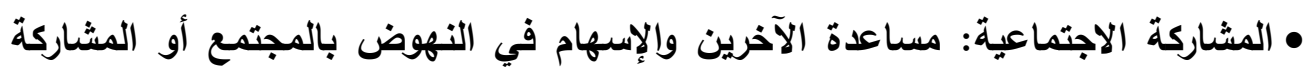
بطريقة أو بأخرى يشعر الفرد بأنه أكثر إيجابية، وتمنحه مشاعر طيبة تشعره بالتحسن والرضا عن الذات، وتساعد الفرد على روئية مشاكله من زوايا مختلفة. • الحفاظ على التعلم: مواصلة التعلم وتحقيق الأهداف يمنح الطاقة، ويساعد على تواجد أفكار جديدة في عقل الفرد، ويتيح الفرصة للتفكير في الأثياء والنظر إلى المواقف بطرق مختلفة، مما يكون له تأثير إيجابي على حياة الفرد ككل . 
• الامتنان: قضاء بعض الوقت يومياً للتفكير في الأشياء التي تستحق الامتنان لها والتركيز عليها في حياة الفرد، والتذكير بالتجاحات والانجازات والأشياء الإيجابية التي حدثت في حياته، والتي تشعره بتقدير الذات .

رابعا : الاتجـاهات العلميـة : | (1) طبيعة الاتجاهات العلمية :

تميز العصر الذي نعيشه الآن بالتقدم العلمي الهائل والتسارع المذهل في شتى جوانب المعرفة، الأمر الذي جعل الشرط الأول لبناء نهضة شاملة في مجتمعنا هو ترسيخ ثقافة العلم وتأصيل الوعي العلمي في حياتنا وثقافتنا، فالأمم لا تتقدم بالأماني ولا تتطور بالعودة إلى الوراء، وإنما بالحركة الد عوية إلى الأمام، بما ينطوي عليه ذلك من إدراكها لقيم العلم وإنتاجها على مختلف الأصعدة، وغرس قيم العلم في الحياة اليومية لأفراد المجتمع من خلال العملية التعليمية والتثقيفية للمجتمع ككل · (عاصم كمال حب الدين ومنى عبد الصبور محمد ، (IT. . Y. 19

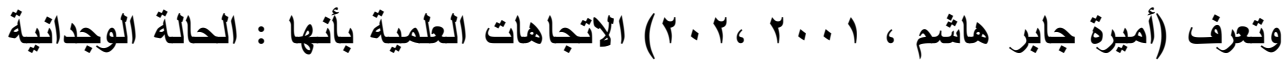
أو الاتفعالية للفرد نحو العلم ، والتى تتكون بناء على ما يوجد لديه من معارف ومعتقدات وخبرات سابقة عن هذا الموضوع ، وقد تؤدى هذه الحالة بالفرد إلى القيام ببعض الاستجابات (اللفظية والعملية ) وقد تكون ( بطيئة - محايدة - عالية ) وتتميز هذه الاستجابات وفقا لما يتطلبه الموقف بما يأتي : التقتح الأهي وحب الاستطلاع ، والتريث فى إصدار الإحكام ،

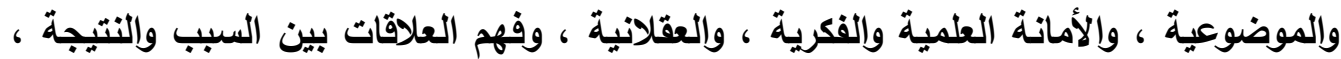
والإيمان بالعلم ، والمثابرة عند استخدام طريقته لحل ما يواجهنا من مشكلات . .

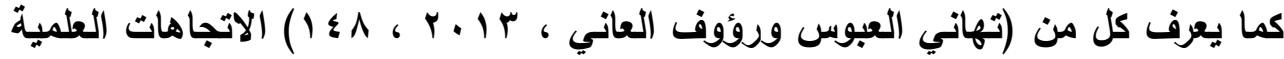

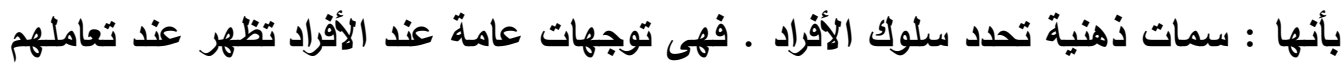
مع مواقف مصوغة تتعلق بموضوعات علمية وتعكس الجوانب الآتية: حب الاستطلاع

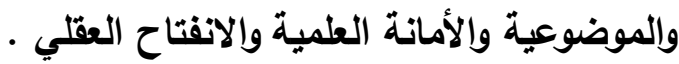
ومما سبق يتضح أن الاتجاه العلمي فى مفهومه يشير إلى مجموعه من السمات العقلية - ذات طابع وجداني - والتي تحدد طبيعة تعامل الفرد مع الظواهر والأحداث العلمية . 


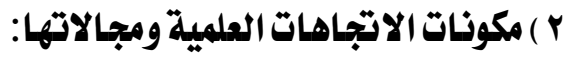

يري التربويين وعلماء النفس أن للاتجاه ثلاث مكونات وهي :

أ) المكون المعرفي: ويعبر عن المعرفة والخبرات والمعتقدات التي يمتلكها الفرد عن موضوعاه

ما.

ب) المكون الوجداني: ويعبر عن شعور الفرد الذي يؤثر في تقبل أو رفض موضوع ما .

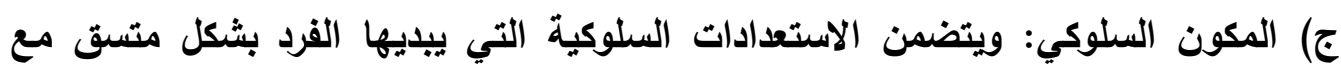
المعارف والانفعالات التي تثكلت لله في المرحلتين السابقتين.

وهذه المكونات الثلاثة لا يمكن أن يعمل كل منها بشكل منفصل ، فهذه المكونات تبدو مترابطة ويصعب فصل كل مكون عن الآخر.(هدى محمد حسين وهنادي عبدالله

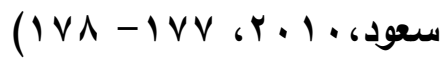
أما عن مجالات الاتجاه العلمي ، فيمكن حصر أهمها فى النقاط التالية : (حجازي عبد

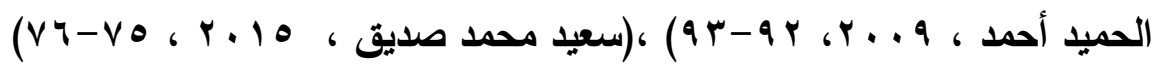
• حب الاستطلاع: ويقصد به رغبة المتعلم في الحصول على المعرفة وإلفهم عندما يواجه مواقف جديدة يصعب عليه تفسيرها في ضوع ما يمتلكه من معلومات. • الإيمان بالطريقة العلمية:وتعنى إيمان المتعلم بأهمية الملاحظة والتجريب فى الوصول هن إلى الحقائق العلمية،والثعور بأن الطريقة العلمية تصحح نفسها،والإيمان بالسببية القائمة على أسس موضوعية. • الأمانة العلمية: تشير إلى توخي المتعلم الدقة في الحفاظ على نتائج الدراسات والأبحاث أو الأعمال التي يقوم بها الآخرون مع الاعتراف بجهودهم وتقبل أفكارهم بصدق وأمانة. • الموضوعية: وهي تستخدم للإثارة إلى عدم تحيز المتعلم أو تعصبه عند اختياره لأفكار أو كتابة ملاحظات عن موضوع ما أو عند حل مشكلة ما. • التروي في إصدار الأحكام: ويعني عدم تسرع المتعلم في إبداء الرأي ، والحذر من

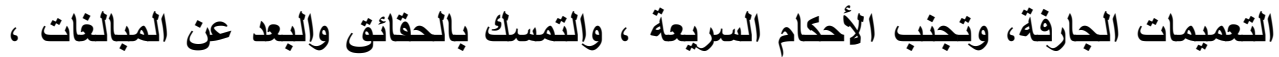
ووضع الأحكام بناءا على الحقائق . 
• الإيمان بقرة العلم على حل المشكلات: ويعني إيمان المتعلم بالدور الإيجابي للعلم وقدرته على حل المشكلات الحالية والمستقبلية ، والإيمان بالعلاقة الوثيقة بين العلم والمجتمع ، والاعتقاد بأن النظريات العلمية لها تطبيقات عملية تخدم المجتمع . • فهم علاقات السبب والنتيجة: وهو البحث عن الأسباب الحقيقية لحادثة أو موقف وفحص بان ما يُعرض من ظواهر للتوصل إلى النتيجة الحقيقية للأحداث، علاوة على إيجاد سبب علمي لعلاقة بين حادثتين. • التقتح الذهني وسعة الأقق : ويعنى إظهار المتعلم لسلوكيات ايجابية نحو الحقائق والنظريات العلمية غير التقليدية ، وأيضا المرونة العقلية فى البحث العلمي وتقبل الآراء المختلفة، وتكوين الرأي العلمي وفقا لوجهات نظر متباينة . خامسا: دور نظريـة الذكاء الناجع في تنميـة المفاهيه والتفكير الإيجابي والاتجاهات العلمية من خلال دراسة المواد الفلسفية :

1 ) دورنظرية الذكاء الناجح فى تنمية المفاهيم من خلال دراسة المواد الفلسفية ؛

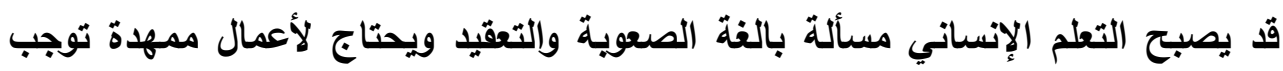
على الإنسان أن يستجيب باستجابة محددة لكل مثير يواجهه فى حياته ، ولكن الإنسان ولحسن حظه لا يتعامل مع المثيرات التي يواجهها في بيئته بهذه الطريقة ،لأن لديه القدرة

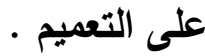

ولقد استخلص جانييه (Gagne) ثلاثة أفكار رئيسية حول المفهوم وطبيعة تعلمه وهي: • المفهوم عمليات عقلية استقلالية . • يتطلب تعلم المفهوم عمليات التمييز بين الأمثلة واللاأمثلة. • الأداء الأي يال على تمكن المتعلم من تعلم المفهوم هو قدرته على وضع الأمثلة

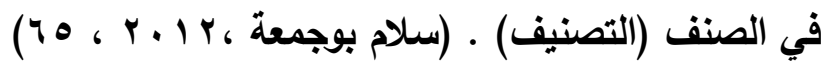
وفى ضوء أفكار (جانيية) السابقة عن طبيعة تعلم المفاهيم فإن نظرية الأكاء الناجح تمثل أداه فعالة لتنمية المفاهيم لاى الطلاب.حيث يشير (Sternberg,2002,383-384) أن الطلاب يتعلمون بشكل أكثر فعالية من خلال التدريس القائم على نظرية الذكاء الناجح. حيث يتضمن هذا التدريس التوجيه والتقييم التحليلي والإبداعي والعملي ، وكذلك الذاكرة ، كما أنه يساعد الطلاب على التعرف على نقاط القوة والاستفادة منها ، وفي الوقت نفسه التعرف 
على نقاط الضعف وتصحيحها أو تعويضها. ويالتالي فهو يمثل أداة فعالة لرفع وزيادة

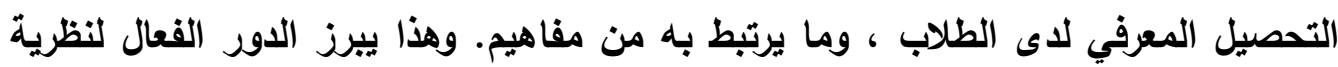
الأكاء الناجح فى تنمية المفاهيم لاى الطلاب وفق المستويات المعرفية المختلفة للأهداف ـ كما أنه من خلال تحليل بنية الأكاء الناجح ومكوناته، فإنه يلاحظ تثابها كبيرا بين تلك لته المكونات وبين تصنيف بلوم لمجالات التعلم _ والتى غلب عليها الطابع المعرفي المفاهيمى حيث صنف الخبرات التعليمية في شكل هرمي متدرج الصعوية (المعرفة - الفهم - التطبيق التحليل - التركيب - التقويم) • حيث أن التعليم من أجل التفكير الإبداعي يشابه التعليم من من مليه أجل التركيب عند بلوم ، والتعليم من أجل التفكير العلمي يشابه إلى حد كبير التعليم من أجل

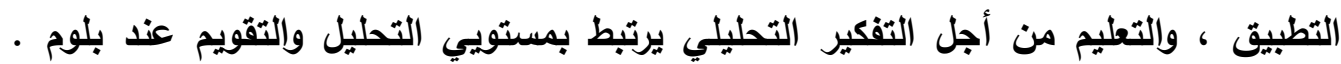

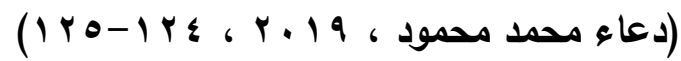
وهذا ما يجعلنا نستخلص أن تنمية القدرات الإبداعية والتحليلية والعملية لدى الطلاب ، يرتبط بالضرورة بتنمية المفاهيم في مستوياتها المختلفة بداءً من المعرفة وانتهاءاً بالتقويم . وفى مجال تقويم تعلم المفاهيم يوضح (Sternberg,2015,76-77) أن الاختبارات التقليدية القياسية تقيم فقط عينة ضيقة من القدرات المطلوية للنجاح في المدرسة وفي الحياة ، وفي المقابل تؤكد نظرية الذكاء الناجح أن الأكاء ينظوي على مهارات إبداعية في إنتاج أفكار جديدة ، ومهارات تحليلية في تقييم ما إذا كانت الأفكار جيدة ، ومهارات عملية في وضع الأفكار موضع التنفيذ وفي إقناع الآخرين بقيمة الأفكار . وهذا يؤكد أن نظرية الذكاء الناجح لا تتعامل فقط مع المستويات المعرفية الدنيا من تعلم المفاهيم ، والخاصة بقرات الطلاب على تذكر واسترجاع المفاهيم ، وإنما تهدف أيضا إلى مئ لهن تنمية المستويات العليا الخاصة بتطبيق وتحليل وتركيب وتقويم المفاهيم.

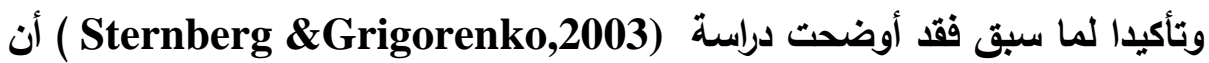
التدريس بنظرية الذكاء الناجح يعمل علي زيادة التحصيل الدراسي ومهارات التفكير الإبداعي

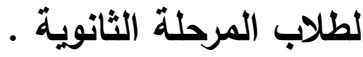
ومن جهة أخرى فإن للمفاهيم أهمية كبيرة في تدريس المواد الفلسفية ، فهي تعد وإحدة

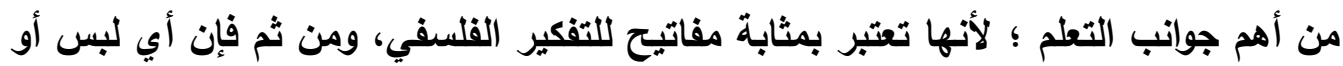


غموض فيها يُعد سبيًا في تعثر فهم الفلسفة كمادة دراسية . ويرى الباحثان أنه يمكن تنمية المفاهيم فى ضوء مناهج المواد القلسفية بالمرحلة الثانوية من خلال ما يلي : • استخدام طرق واستراتيجيات تدريس قائمة على اكتشاف المفهوم وتفسيره وتطبيقه. • توظيف معلمي المواد القلسفية لعمليات انتقال أثر التعلم للمفاهيم الفلسفية والمنطقية ، من خلال تدريسهم لفروع المواد القلسفية المختلفة (القلفة - المنطق - علم النفس - موطي علم الاجتماع ). • استخدام أنشطة تعليمية مرتبطة بالقضايا الحياتية والاجتماعية ، بشكل يساعد الطلاب على توظيف وتطبيق المفاهيم • • صياغة نواتج تعلم الموضوعات والدروس بشكل يستهدف تحقيق القهم العميق للمفاهيم المتضمنة ، ويضمن استيعاب الطالب للمستويات المعرفية العليا في تعلم المفاهيم . r ) دور نظرية الذكاء الناجح فى تنمية التفكير الإيجابي من خلال دراسة المواد الفلسفية : تنظر معظم الأدبيات التربوية إلى التفكير الايجابي باعتباره عادة عقلية يمارسها الفرد

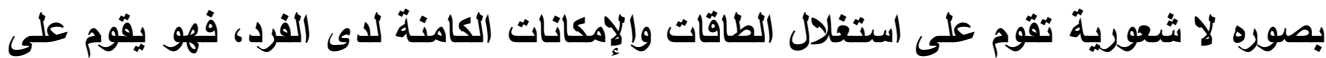
قرة الفرد على بناء وتنظيم أفكاره ومعارفه وخبراته، والاختيار من بينها بما يلائم الموقف الحالي، وتركيز شعوره، وتوجيه سلوكياته نحو تحقيق أهدافه التي يسعى إليها، والتخطيط الجيا

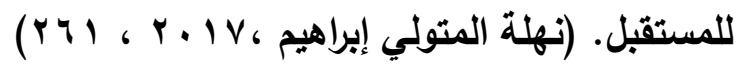
وفى ضوء هذا التصور السابق ، فإن التفكير الايجابي يعد أحد تطبيقات نظرية الذكاء الناجح ، فإذا كانت نظرية الذكاء الناجح تقوم فى مجملها على استغلال نقاط القوة فى أداء الطلاب ومعالجة وتعويض نقاط الضعف ، فإن الأدبيات التريوية أثنارت إلى أن التفكير الايجابي يمثل نتاج للخبرات الذاتية والسمات الفردية الايجابية ، فهو ليس مجرد البحث عن جواتب القصور والضعف الموجودة لدى الطالب، إنما هو فرصة للبحث عن مكامن القوة من

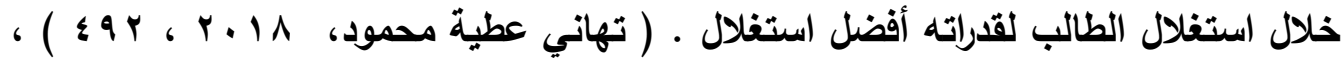

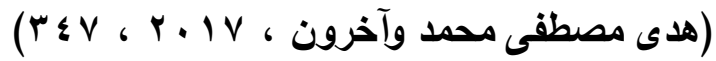
ويتضح من ذلك أن تنمية القدرات التحليلية والإبداعية والعملية لاى الطلاب ينمى لايهم مهارات التفكير بشكل عام ، ويجعهم يفكرون بطريقة أكثر ايجابية عندما يتعرضون للمواقف 
المختلفة ، ويقلل من تعرضهم للمشكلات ، ويساعدهم في وضع حلول لبعض ما يواجهونه من عقبات وتحديات في حياتهم اليومية . . وقد أفرزت الأدبيات التريوية العديد من الطرق والأساليب لتنمية التفكير الايجابي يتقابل اغلبها مع إجراءات وأسس الأكاء الناجح ـ فقد اتجه البعض إلى طرح بعض الاستراتيجيات لتنمية التفكير الايجابي لاى الطلاب منها : إستراتيجية الاختيار الواعي - سجلات التفكير البرمجة الإيجابية للأات- الحديث للأات-المراقبة الذاتية- تغيير التركيز -إعادة التعريفالتجزئة- - إستراتيجية تغيير الماضي - القيم العليا- الشخص الآخر- النتائج الايجابيةالبدائل ...الخ، واتجه البعض الآخر إلى طرح مجموعة من الفنيات والإرشادات العامة التي

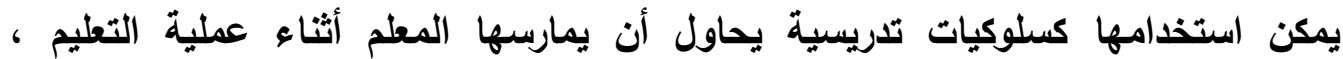
ويمارسها الطالب أثناء عملية التعلم، ومنها : التركيز على الإيجابيات- تخطي السليباتجعل الذهن متفتحا- البحث عن السعادة- توقع الأفضل- محارية الغضب- الشعور بالقبول مراقبة الأفكار - وجود أهداف علمية وعملية- مراجعة النفس وتقويمها - مساعدة الآخرين التفاؤل ومقاومة الغضب- التجاهل للأفكار السلبية- وصف الأات ببعض الكلمات الإيجابيةالتفاؤل والصدق مع الذات- الاحتفاظ بالأهداف والمشاعر في دفتر خاص- الشعور بالرضا عند الحصول على الهذف- تحويل الأفكار السلبية إلى إيجابية- زرع الطموح في الحياةالمثابرة في تحقيق التفكير الإيجابي-احترام الاختلاف مع الآخرين- تدريب العقل اللاواعي

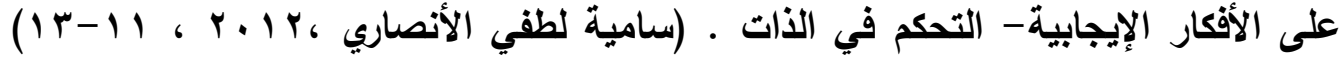

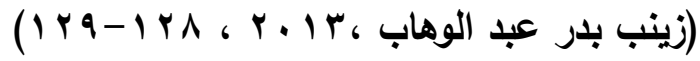

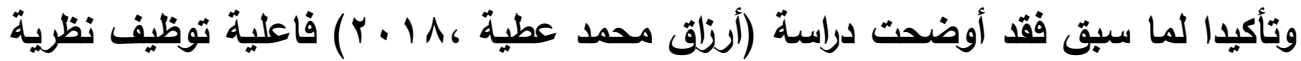
الذكاء الناجح في تدريس الاقتصاد المنزلي علي تنمية التفكير الإيجابي والمرونة العقلية لادي

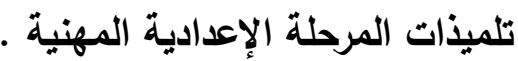
وفى ضوء العلاقة السابقة بين نظرية الأكاء الناجح والتفكير الإيجابي ، يرى الباحثان إمكانية تنمية مهارات التفكير الايجابي فى ضوء تدريس مناهج المواد القلسفية بالمرحلة الته الثانوية ، وذلك من خلال ما يلي : الثنابه - - تضمين مناهج المواد القلسفية بعض الأهداف التي تتقابل بشكل مباشر وغير مباثر مع مهارات التفكير الايجابي ، مثل علم النفس السعادة ، علم النفس الايجابي ، 
المشكلات النفسية فى مرحلة المراهقة وكيفية مواجهتها (مثل الاكتئاب - قلى الامتحانات - مشكلات التوافق النفسي والاجتماعي ، الاغتراب ...الخ) ، بناء الاستدلالات المنطقية وكيفية تطبيقها على حل المشكلات والتتلب على العقبات ، المشكلات الاجتماعية وكيفية مواجهتها والتعامل معها وإقتراح حلول لها ، بالإضافة إلى موضوعات فلسفة السعادة . - - توظيف معلم المواد الفلسفية لاستراتيجيات وطرق التدريس التي تحقق ممارسة الطلاب لمهارات التفكير الايجابي ، مثل : الأمثلة الشارحة ، المدخل الإنساني ، قبعات التفكير

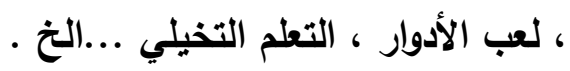
- توجيه المعلمين لتنفيذ بعض الممارسات أثناء تدريس موضوعات المواد القلسفية ، وذلك بهدف تنمية بعض القيم الخاصة بالايجابية وإلتفاؤل لدى الطلاب ، مثل : الاستقلالية فى الرأي ، الانفتاح على خبرات الآخرين ، التفكير بشكل جماعي ، التواضع العلمي ، التفكير بشكل ناقد ، إتباع الموضوعية فى التفكير ، التساؤل

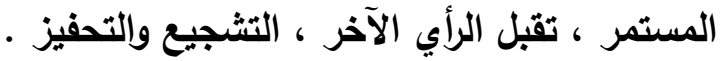
- التويع فى الأنشطة التعليمية المرتبطة بمناهج المواد الفلسفية ، بحيث تريط تلك الأنشطة بين الموضوعات التي يتم تدريسها وتطبيقاتها فى الحياة اليومية ـ حيث أن مثل هذه الأنشطة تنمى لاى الطلاب العديد من القيم والأهداف المرتبطة بالتفكير الايجابي ، مثل : الثقة بالنفس ، تقدير الذات ، حب الاستطلاع والتفتح المعرفي،

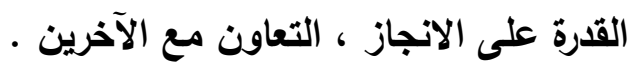

r ب ) دور نظرية الذكاء الناجح فى تنمية الاتجاهات العلمية من خلال دراسة المواد الفلسفية : التدريس من خلال نظرية الذكاء الناجح يزود المتعلمين بصورة تعليمية تتلاعم مع نماذج القدرات العقلية لايهج ، فالطلاب الذين يتمتعون بالذكاء الناجح هم فاعلون ، ولديهم اتجاه أنهم يستطيعون فعل الأثياء ، ويدركون محددات ما يمكنهم عمله وإنجازه ـ ويالتالي فإن ملائمة تلك الممارسات التعليمية وتكيفها مع البناء العقلي للمتعلم يدعم التوجه الايجابي للطالب نحو المادة المتعلمة وما تتضمنه من موضوعات وأفكار ـ وذلك على اعتبار أن الاتجاه يشير في طبيعته إلى استعداد نفسي وعصبي متعلم يكونه الفرد تجاه موضوع أو شيء أو موقف معين يظهر ذلك بوضوح من خلال سلوك الفرد بشكل ايجابي أو سلبي تجاه 
ذلك الموضوع • (Sternberg \& Grigorenko,2003) ، ( زياد محمد قباحة ، ؛ 1 ـ ب ،

كنلك يظهر الجانب الوجداني لنظرية الذكاء الناجح من خلال إيضاح (سترنبرج) لأهمية التذريس بهذه النظرية لكل من المعلم والمتعلم ، فالنسبة للطلاب يتعلمون بشكل أكثر فاعلية مما يتعلمون من خلال الطرق التقليدية . حيث أن التدريس وفق الذكاء التاجح يضمن لهم التدريس بطريقة تتناسب بشكل أفضل مع أنماط قراتهم. كما يتضمن مساعدة جميع الطلاب على الاستفادة من نقاط قوتهم وتعويض أو تصحيح نقاط الضعف لايهم ، وذلك من خلال التدريس بطريقة توازن بين التعلم من أجل الذاكرة والتفكير التحليلي والإبداعي والعملي . ويالنسبة للمعلمين فإن التريس القائم على الذكاء الناجح يساعد المعلمين في الوصول إلى عدد أكبر من الطلاب من أساليب التدريس التقليدية التي تؤكد على الذاكرة والتعليم التحليلي. فمن خلال الأكاء الناجح يتبع المعلم عددًا من الأفكار الأساسية ، ولا توجد طريقة واحدة صحيحة للتدريس والتعلم. علاوة على ذلت لا توجد طريقة صحيحة واحدة لتقييم تحصيل الطلاب ، بل يجب أن يوازن التدريس والتقييم بين التفكير التحليلي والإبداعي والعملي ، مع

(Sternberg,2004,274-275). توفير خيارات متعددة ومتنوعة في تقييم الطلاب

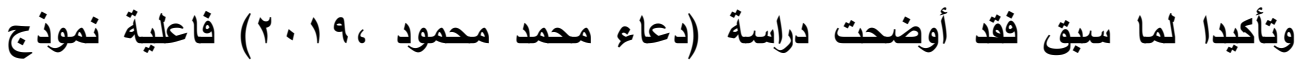
تدريسي مقترح في ضوء نظرية الذكاء الناجح في تنمية الفهم العميق وحب الاستطلاع كأحد أبعاد الاتجاه العلمي - لاي طلاب المرحلة الثانوية . ووفقا لما سبق فإن تضمن مناهج المواد القلنفية في المرحلة الثانوية لبعض البض الموضوعات والأفكار والمفاهيم ذات الطبيعة العلمية من شأنه أن ينمى لاى الطلاب الاتجاهات العلمية بما تتضمنه من أبعاد ومجالات مثل : حب الاستطلاع، التقتح الذهني وسعة الأفق ، الموضوعية ، الأمانة العلمية ، التروي والمثابرة ..الخ · ومن أهم تلك الموضوعات: معنى العلم وأخلاقيات العالم ، خصائص التفكير العلمي وخطواته ، الفلسفة والعلم ، الثورات البيولوجية ، الهندسة الوراثية ، الأخلاق الطبية وزراعة الأعضاء ، التحري

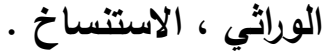
وخلاصة القول أن نظرية الأكاء الناجح لها دور في تنمية المفاهيم والتفكير الإيجابي والاتجاهات العلمية ، وهذا ما أكدته الأدبيات النظرية والدراسات السابقة ، كما أنه يمكن 
استخدام تلك النظرية في تحقيق العديد من نواتج التعلم المرتبطة بدراسة المواد القلسفية .

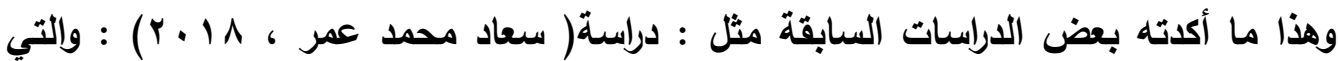
أوضحت فاعلية برنامج قائم علي نظرية الذكاء الناجح فى تنمية المهارات القلسفية لادي

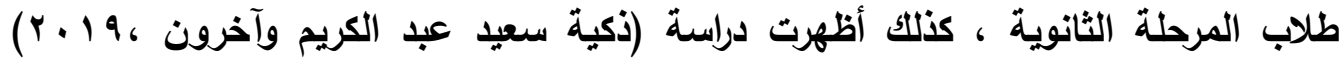
فاعلية استخدام نظرية الأكاء الناجح في تدريس الفلسفة على تنمية مهارات معالجة المعلومات لدي طلاب المرحلة الثانوية ، وأخيرا أوضحت دراسة (شعبان عبد العظيم أحمد

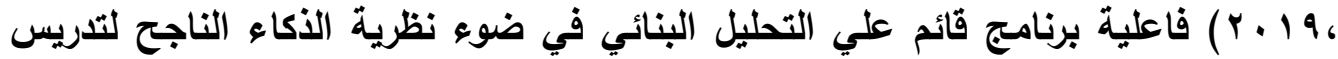
علم النفس على تنمية التفكير التخيلي والمرونة المعرفية لاي طلاب المرحلة الثانوية .

\section{إعـداد أدوات الثيـاس والتجريـب}

لما كان البحث الحالي يهذف إلى الكثف عن فاعلية استخدام نموذج مقترح قائم على نظرية الذكاء الناجح في تدريس وحدة مبادئ التفكير العلمي على تنمية المفاهيم وإلتفكير الايجابي والاتجاهات العلمية لدى طلاب الصف الأول الثانوي ـ فإن ذلك يتطلب إعداد الأدوات وإلمواد الآتية التالية : أولا: قائمة أبعاد ومهارات التفكير الإيجابي المناسبة لطلاب الصف الأول الثانوي. ثانيا : بناء النموذج المقترح لتدريس وحدة مبادئ التفكير العلمي وفق نظرية الذكاء الناجح. ثالثا : إعداد دليل المعلم في النموذج المقترح • المعاد رابعا : إعداد كتيب الطالب في النموذج المقترح . خامسا : إعداد اختبار المفاهيم في وحدة " مبادئ التفكير العلمي " . سادسا : إعداد اختبار التفكير الإيجابي • سابعا: إعداد مقياس الاتجاهات العلمية .

أولا : إعداد قائمة بأبعاد ومهارات التفكير الإيجابي : وقد تم إعدادها وفقا للخطوات الآتية : ( ) تعديد الهدف من القائمـة: تهدف هذه القائمسة إلى تعديد أبعاد ومهارات التفكير الإيجابي المناسبة لطلاب الصف الأول الثانوي . r) تحديد مصادر اشتقاق القائمة: اعتمد الباحثان في إعداد قائمة أبعاد ومهارات التفكير الإيجابي على المصادر الآتية : 
• موضوعات وحدة " مبادئ التفكير العلمي " المقررة على طلاب الصف الأول الثانوي في

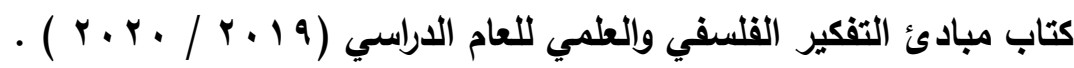
• بعض البحوث والداسات العربية التي تناولت أبعاد ومهارات التفكير الإيجابي. • بعض البحوث والدراسات الأجنبية التي تناولت أبعاد ومهارات التفكير الإيجابي.

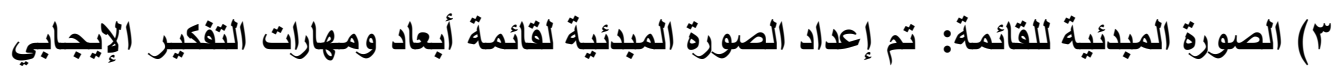

$$
\text { ، والتي ضمت (T) }
$$

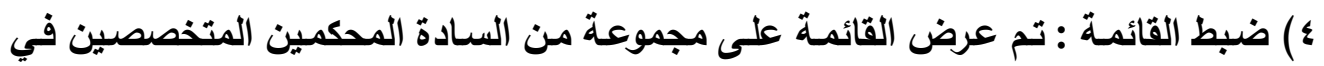

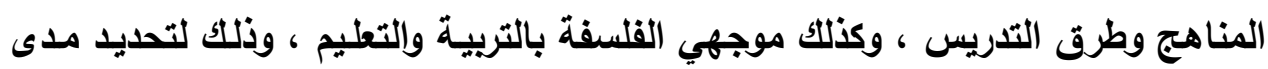
مناسبة هذه المهارات لطلاب الصف الأول الثانوي وارتباطها بموضوعات وحدة " مبادئ ودئ

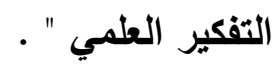
ه) الصورة النهائيسة للقائمسة : من خـلال مراجعة القائمسة في ضـوء آراء السـادة المحكمين وحسـاب نسـب اتفـاقهم على تلك المهارات ، تـم إعداد الصـورة النهائيـة لقائمسة أبعـاد

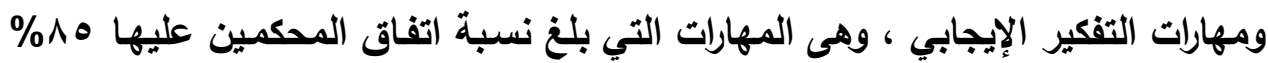
فأكثر • وقد تضمنت القائمة النهائية (^) أبعاد ، هي كالتالي : - - الميل إلى التفاؤل والتوقع الايجابي • - - ضبط الانفعالات والتحكم في العمليات العقلية العليا . - - تقبل المسئولية الثخصية . - - ملاحظة الأفكار واستبعاد السلبي منها . - - التركيز على الجانب الايجابي للموضوع أو المشكلة .

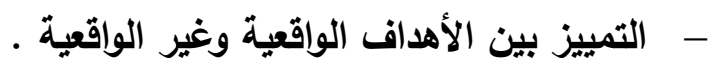
- - تقبل الاختلاف عن الآخرين - - الرغبة في المجازفة الايجابية . 
ثانيا : بناء النموذج المقترح في ضوء نظرية الذكاء الناجح :

تم بناء النموذج المقترح لتريس وحدة مبادئ التفكير العلمي وفق نظرية الذكاء الناجح

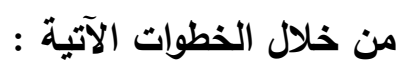

\section{( ) تحليد أسس ومبادئ بناء النموذج المقترح :}

في ضوء مبادئ التعليم والتعلم وفق نظرية الذكاء الناجح ، وارتباطها بمستويات الدفاهيم

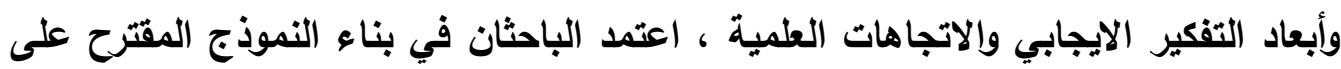

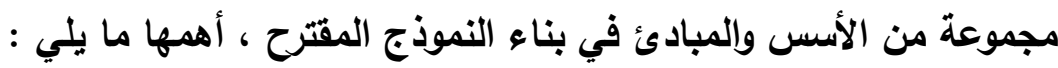

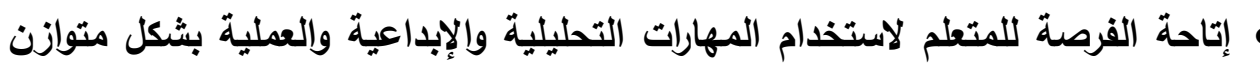
من خلال الأنثطة التي تخاطب هذه المهارات الثلاثة .

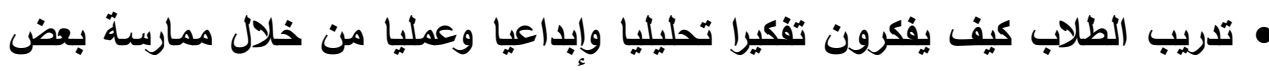

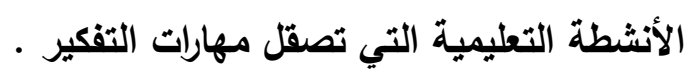

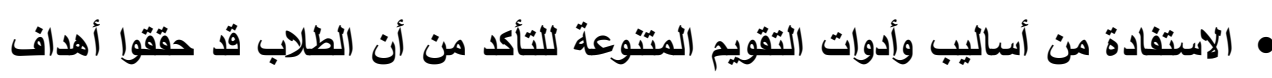

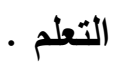
• استخدام تقتيات التظذية الراجعة ، من خلال تعزيز نقاط القوة وعلاج جوانب الضعف

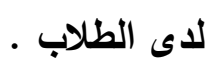

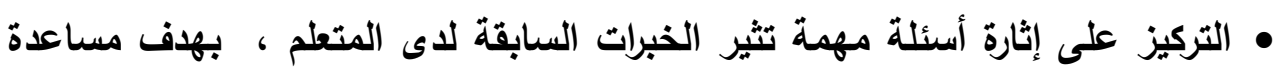

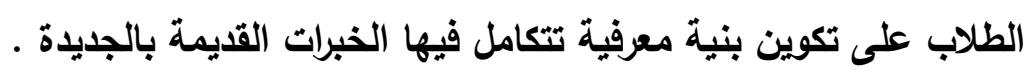
• إتاحة الفرصة للطلاب لتحليل بعض القضايا والأحداث الجارية ، من خلال التهابل التركيز على الجانب الايجابي للقضية أو العدث ، واستبعاد ما يطرح من أفكار سلبية حول تلك القضايا والأحداث . • إتاحة ممارسة الطلاب لبعض الأنثطة التعليمية التي تهذف إلى تدريبهم على التمييز

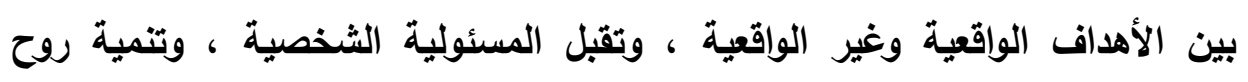

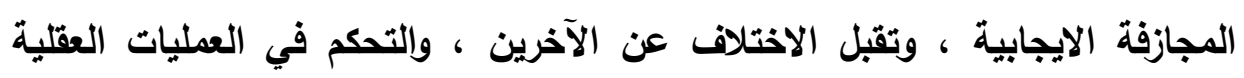

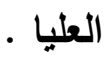
• ريط إجراءات وخطوات النموذج بمستويات المعرفة المختلفة التي يجب على الطالب اكتسابها حول المفاهيم التي تتضمنها وحدة " مبادئ التفكير العلمي التعدئ 
• التأكيد على مراعاة الفروق الفردية بين الطلاب ، من خلال التنوع في استراتجيات التدريس المستخدمة ، والتنوع في أنثطة ومصادر التعلم ، والتنوع في أساليب التقويم المختلفة .

• تضمين النموذج المقترح بعض الإجراءات والمهام التي تضمن تنمية الميول

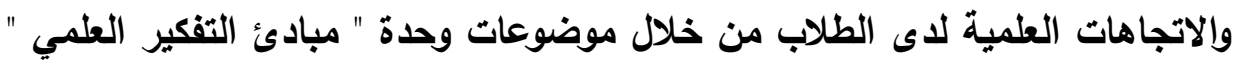
، خاصة وان هذه الوحدة توفر العديد من المعارف والخبرات التي تضمن ممارسة

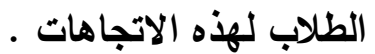
• إعداد مهام تقويمية محددة وهادفة وذات معنى ، بحيث توفر صورة حقيقية عن الاتهات جواتب القوة والضعف في مستوى الطلاب ، بحيث يتم تدعيم نقاط القوة ، والعمل على لقدي تعويض ومعالجة نقاط الضعف . • الربط بين أنثطة تنمية قدرات الطلاب التحليلية والإبداعية والعملية وممارسة الطلاب

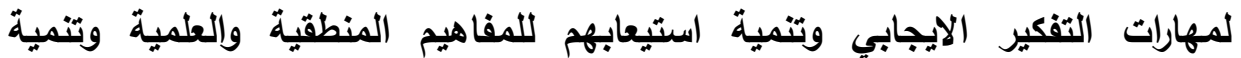
اتجاهاتهم العلمية .

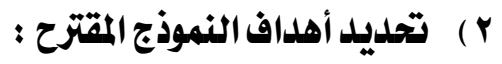
يهدف هذا النموذج إلى تنمية المفاهيم المتضمنة في وحدة مبادئ التفكير العلمي ، وأبعاد التفكير الايجابي ، والاتجاهات العلمية لاى طلاب الصف الأول الثانوي من خلال

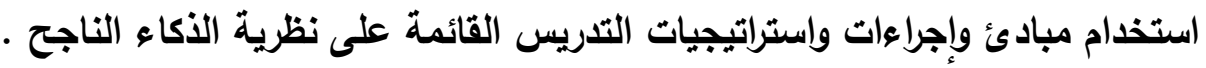

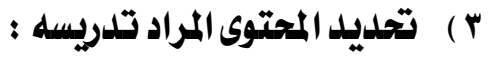
اختار الباحثان وحدة مبادئ التفكير العلمي المقرة على طلاب الصف الأول الثانوي لتكون المحتوى الذي يتم تدريسه بالنموذج المقترح ، وذلك لاشتمالها على بعض الذبان التبرات

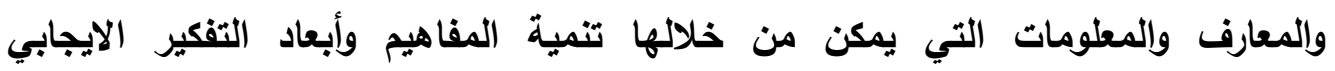
والاتجاهات العلمية .

₹ ) تحديل خطوات وإجراءات التدريس بالنموذج المقترح : في ضوء مفهوم التعلم وفق نظرية الذكاء الناجح ، فضلا عن مكوناتها الرئيسية المتمثلة

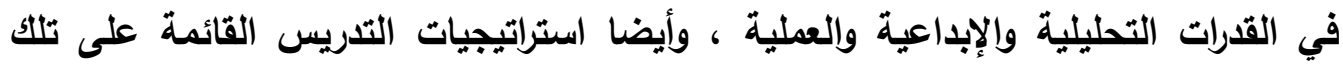
النظرية ـ حلد الباحثان خطوات وإجراءات التدريس بالنموذج المقترح ، وذلك كالتالي : 
- المر حلة الأولى : مرحلة التهميل وتنشيط الذاكرة : وتتضمن ما يلي : • إثارة انتباه الطلاب من خلال فكرة إبداعيه ، ألغاز ، صور ، مقاطع فيديو ، مواقف مهان تعليمية ذات صلة بموضوع الارس .

• توجيه الطلاب لتحديد المعاني المتضمنة فيما تم عرضه من صورة أو لغز أو فكرة . • توجيه الطلاب لطرح بعض الأسئلة المتعمقة في ضوء ما توصلوا إليه من معاني . - المرحلة الثانية : استثارة المعرفة السابقة وتحفيز التفكير : وتتضمن ما يلي : • استثارة معلومات الطلاب السابقة عن موضوع الارس من خلال طرح مجموعة من الأسئلة في شكل أسئلة للعصف الذهني • • إتاحة الفرصة للطلاب للتفكير في إجابات لهذه الأسئلة ، مع الحرص على مشاركة جميع الطلاب .

الاستماع إلى إجابات الطلاب وتقييمها ، بحيث يتم التوصل إلى تحديد البنية المعرفية

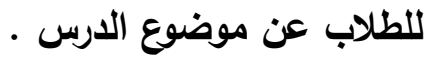
• يتم عرض التعلم الجديد بشكل عام من خلال خريطة معرفية للمفاهيم والعناصر الأساسية

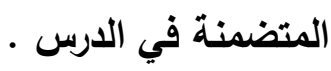
• توجيه الطلاب إلى استخدام عمليات الترميز والتخزين في مراجعة وفحص الخريطة المعرفية لمفاهيم وموضوعات الدرس .

- المرحلة الثالثة : تلدعيم القدرات الثلاث للذكاء الناجح : وتتضمن هذه المرحلة استخدام مبادئ وأسس التعلم المستتد إلى الاماغ في تنمية وتدعيم قدرات الأكاء الناجح التحليلية والإبداعية والعملية ، وذلك من خلال ما يلي : • يتم تقسيم الطلاب إلى مجموعات عمل تعاونية ، حيث أن الدماغ ذاته ينمو ويتطور من خلال التفاعل والتعاون مع الآخرين . • ينوع المعلم في أساليب عرض محتوى الدرس سواء من خلال أورلق العمل أو الاستعانة بالكتاب المدرسي على جهاز التابلت ـ وذلك لإحداث توازن بين القدرات التحليلية

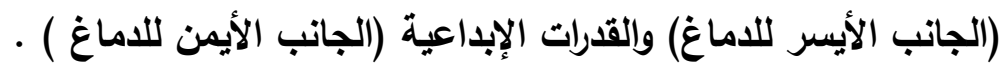
• توجيه الطلاب لعمل مخططات معرفية توضح الأفكار والعناصر الأساسية لموضوع الدرس . 
• توجيه الطلاب إلى تنفيذ بعض أنثطة التطم المرتبطة بموضوع الارس ، بحيث يتضمن تنفيذ تلك الأنثطة استخدام الطلاب لقدراتهم التحليلية والإبداعية والعملية .

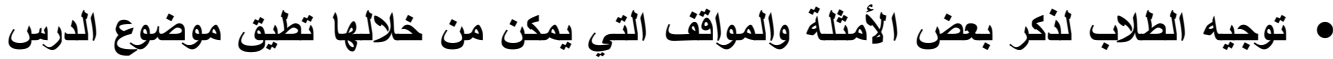
وعناصره على مجالات الحياة الواقعية واليومية ، وذلك لتنمية وتدعيم القدات العملية

- المرحلة الرابعة : مرحلة التلدعيم والمتابعة : وتتضمن ما يلي : • توجيه بعض الأسئلة التي تدعم عمليات فهم المفاهيم وتنمى مهارات التفكير العليا لاى

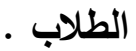

• من خلال إجابة الطلاب على هذه الأسئلة يحدد المعلم نقاط القوة لديهم فيتم تدعيها ، ونقاط الضعف فيتم معالجتها من خلال عرض بعض الأمثلة والأنثطة التعليمية الإثرائية .

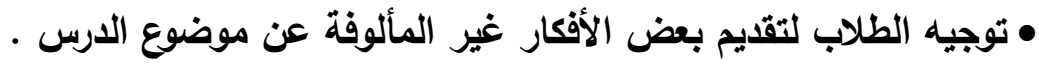

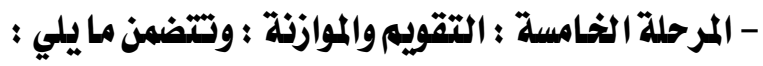

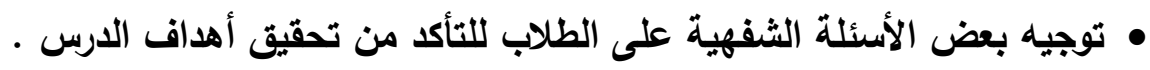

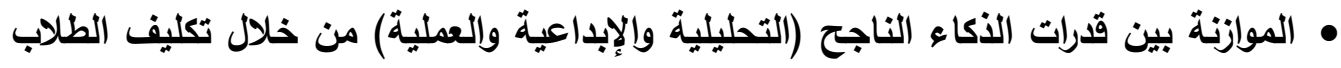
بتنفيذ بعض الأنثطة التعليمية التي تدعم تلك القدرات بشكل متكافئ . 0 ) تحليد استراتيجيات وطرق التدريس المستخدمة في النموذج المقترح :

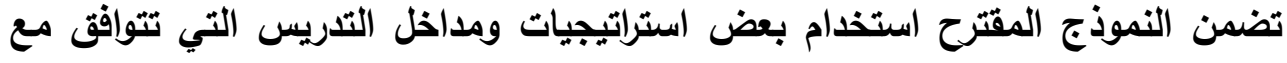
مبادئ وتوجهات نظرية الذكاء الناجح ، وفى نفس الوقت تتناسب مع محتوى وحدة " مبادئ

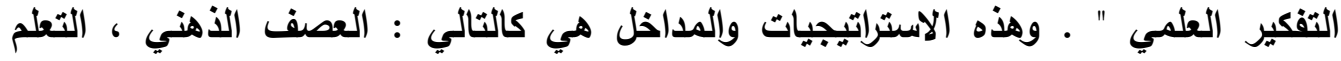
التعاوني ، الخريطة المعرفية ، الأمثلة الثارحة. 7 ) 1 ) تحليد الوسائل التعليمية ومصادر التعلم في النموذج المقترح : حرص الباحثان في بناء النموذج على استخدام وتوظيف بعض الوسائل التطليمية ومصادر التعلم التي تساعد المطلم والطلاب على تحقيق أهداف الدروس وأهداف النموذج

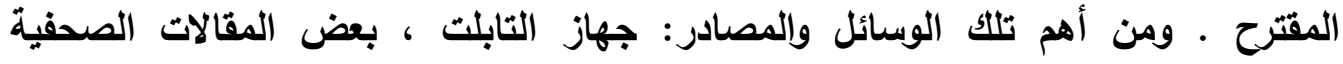

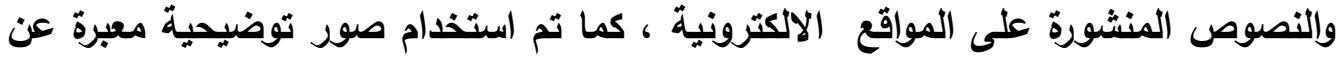


طبيعة كل موضوع من موضوعات الوحدة المختارة بالإضافة إلى استخدام الكتاب المدرسي

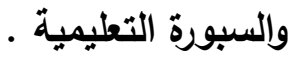

V ) تحليل الأنشطة التعليمية المستخدمة في النموذج المقترح : حرص الباحثان على تنويع الأنشطة المستخدمة في النموذج بين الأنشطة الفردية والجماعية ، وأيضا الأنشطة التي يمكن تنفيذها داخل الغرفة الصفية ، وآخري خارجها. كما

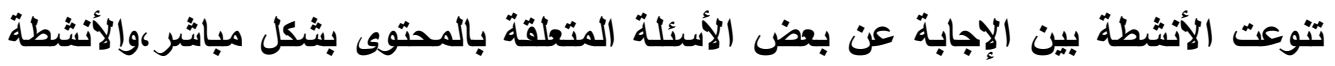
التي تتضمن تحليل الطالب لمقالات ونصوص وفقرات تتصل بشكل غير مباشر بالمحتوى،وتركز على تنمية المفاهيم وأبعاد التفكير الايجابي والاتجاهات العلمية . وقات تضمن النموذج المقترح الأنشطة التعليمية الآتية : •طرح بعض الأسئلة المتعقة عن الصور والأفكار المعروضة في مرحلة التهميد وتنشيط الأكرة .

- الإجابة عن أسئلة للعصف الذهني المطروحة في مرحلة تحفيز التفكير واستثارة المعرفة السابقة. - المشاركة بفاعلية في مجموعات التعليم التعاوني في مرحلة تدعيم القدرات الثلاث للأكاء - الناجح - تنفيذ بعض أنشطة التعلم المرتبطة بموضوع الدرس في مرحلة تدعيم القدرات الثلاث للأكاء - الناجح • عمل مخططات معرفية توضح الأفكار والعناصر الأساسية لموضوع الدرس في مرحلة تدعيم

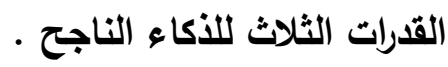
• الإجابة عن أسئلة تدعيم فهم المفاهيم ومهارات التفكير العليا في مرحلة التدعيم والمتابعة . - تقديم بعض الأفكار غير المألوفة عن موضوع الدرس في مرحلة التدعيم والمتابعة .

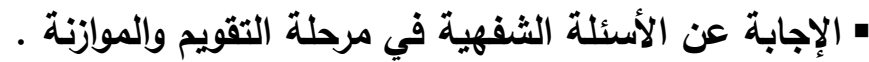
- تنفيذ نشاط تعليمي يدعم القدرات (التحليلية والإبداعية والعملية) بشكل متكافئ والمتضمن في مرحلة التقويم والموازنة . 
A ) تحليل أساليب التقويم المستخلمة في النموذج المقترح :

تم تقويم الطلاب من خلال الأساليب الآتية :

أ) التقويم القبلي : ويتم من خلال تطبيق اختبار المفاهيم ، وإختبار التفكير الايجابي ، ومقياس الاتجاهات العلمية قبليا على الطلاب عينة البحث . ماند

ب)التقويم البنائي : ويتم أثناء تدريس وحدة " مبادئ التفكير العلمي " بالنموذج المقترح ، وذلك من خلال الأسئلة التي يطرحها المعلم خلال مراحل النموذج المختلفة ، وأيضا تنفيذ الطلاب لبعض الأنشطة التعليمية ، إضافة إلى تقويم أدائهم عقب نهاية كل موضوع من

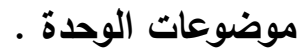

ج) التقويم النهائي : ويتم من خلال تطبيق اختبار المفاهيم ، وإختبار التفكير الايجابي ، ومقياس الاتجاهات العلمية قبليا على الطلاب عينة البحث . ثالثا : إعداد دليل المعلم في النموذج المقترح : قام الباحثان بإعداد دليل للمعلم يوضح كيفية تدريس وحدة مبادئ التفكير العلمي وفق النموذج المقترح.? وقد اشتتمل دليل المعلم على ما يلي:

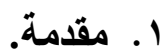
Y. الأهداف العامة لوحدة " وحدة مبادئ التفكير العلمي " من كتاب مبادئ التفكير القلسفي والعلمي " المقرر على طلاب الصف الأول الثانوي . r. التعريف بنظرية الأكاء الناجح وأهمية استخدامها في التدريس . ؛. التعريف بطبيعة المفاهيم وتتميتها .

هـ التعريف بالتفكير الايجابي وأبعاده وأهمية تنميته لدى الطلاب في المرحلة الثانوية . 7 . التعريف بالاتجاهات العلمية وأهمية تنميتها لدى الطلاب في المرحلة الثانوية . V. التعريف بالنموذج المقترح القائم على نظرية الأكاء الناجح وكيفية بنائه ـ . ^. الخطوات الإجرائية لتدريس" وحدة مبادئ التفكير العلمي " وفق النموذج المقترح . 9 . إرشادات للمعلم عند التدريس بالنموذج المقترح . • 1 ـ الخطة الزمنية لتدريس " وحدة مبادئ التفكير العلمي " .

$$
\text { 6 ملحق (0) : دلـيـل المعلــم في النموذج المقترح }
$$


1 1. تدريس موضوعات" وحدة مبادئ التفكير العلمي " وفق النموذج المقترح ـ

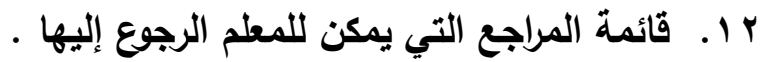
رابعا : إعداد كتيب الطالب في النموذج المقترح : تم إعداد كتيب الطالب بما يتضمنه من مفاهيم رئيسية لكل موضوع من موضوعات وحدة

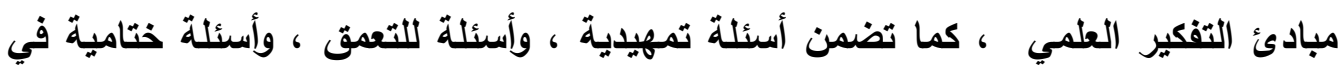
نهاية كل موضوع ، كنلك تضمن الأنشطة التعليمية المدرجة بالنموذج المقترح والتي يقوم بتنفيذها سواء بشكل فردى أو جماعي ، والتي تهذف إلى تنمية استيعابهم للمفاهيم المتضمنة في وحدة مبادئ التفكير العلمي ، وأيضا توفر لهم ممارسة أبعاد التفكير الايجابي لهي

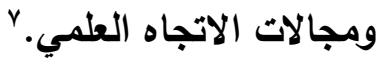
خامسا : إعلاد اختبار المفاهييم في وحلدة "مبادئ التفكير العلمي" : وقد تم إعداده وفقا للخطوات الآتية : (1) تحديد الهذف من الاختبار : يهرف هذا الاختبار إلى قياس مدى نمو المفاهيم لاى طلاب الصف الأول الثانوي ، وذلك بعد دراستهم لوحدة " مبادئ التفكير العلمي " باستخدام نموذج تدريسي قائم على نظرية الأكاء الناجح • (r) تحديد المحتوى الأي يقيسه الاختبار: لقد اقتصر الاختبار على الموضوعات التي تضمنتها وحدة " مبادئ التفكير العلمي " وهي :

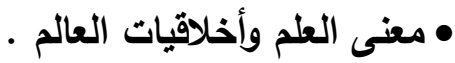
• خصائص التفكير العلمي وخطواته .

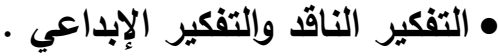

(r) تحليل محتوى الوحدة : لقد مر تحليل محتوى الوحدة في هذا البحث بالخطوات الآتية :

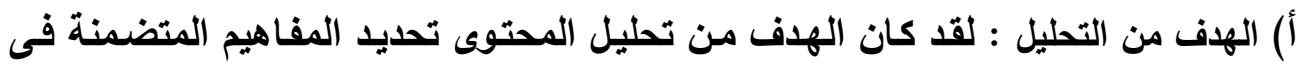
وحدة " مبادئ التفكير العلمي " المقررة على طلاب الصف الأول الثانوي . ب) تحديد فئات التحليل : تتحدد فئات التحليل في البنية المعرفية لمحتوى الوحدة بالمفاهيم 


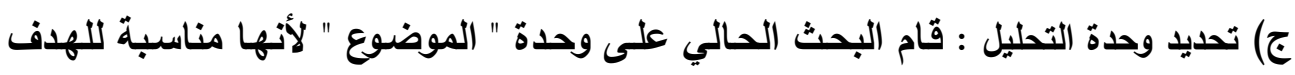
من التحليل ، ويقتصر التحليل على المضمون اللفظي لمحتوى الوحدة المختارة.

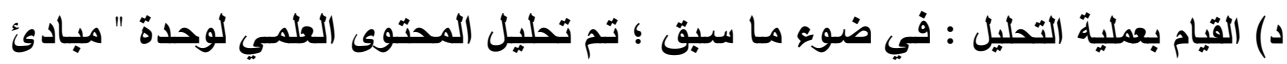

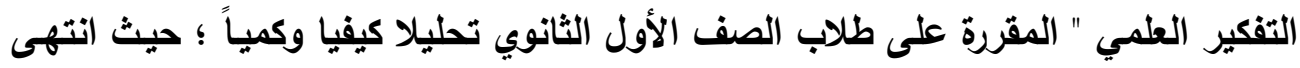
التحليل إلى استخراج (؛) مفاهيم أساسية موزعة على موضوعات الوحدة الرئيسية ـ وهذه الكيد المفاهيم هي : العلم ، التفكير العلمي ، التفكير الناقد ، التفكير الإبداعي .

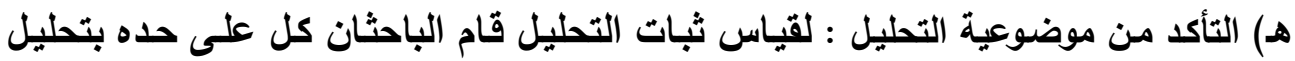
نفس المحتوى وذلكك بعد توضيح وتحديد فئات التحليل ووحداته ، ثم تم حساب معامل فئل

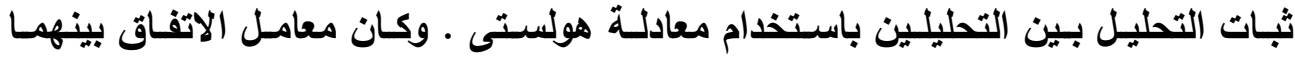
يساوى (. . 1\%) وهى القيمة الأعلى لثبات التحليل .

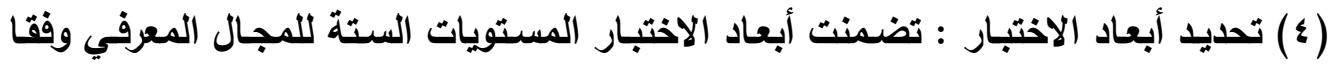

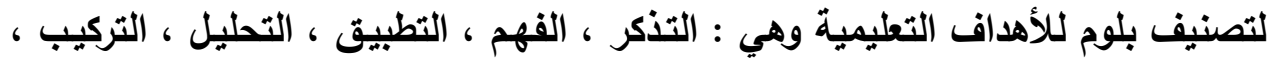
التقويم الفنائ

وقد قام الباحثان بصياغة الأهداف السلوكية الخاصة بكل موضوع من موضوعات الوحدة

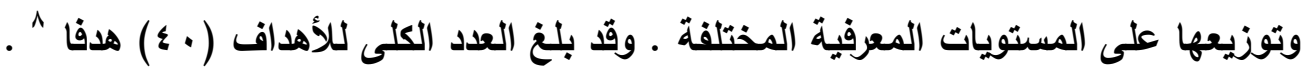
(ه) إعداد جدول المواصفات : وقد تم إعداد جدول مواصفات الاختبار في وحدة " مبادئ

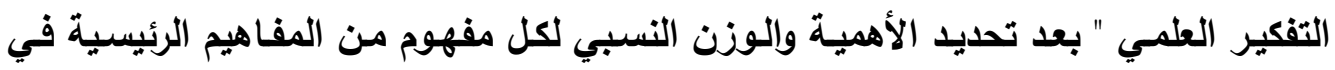
الوحدة ، ويوضحه جدول (ץ) كالتالي :

8 ملحق (و) : توزيع الأهداف السلوكية لوحدة مبادئ التنكير العلمي على المفاهيم المتضمنة في الوحدة . 
استخدام نموذج مقترح قائم على نظرية الذكاء الناجح

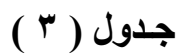

جدول مواصفات اختبار المفاهيم في وحدة " مبادئ التفكير العلمي "

\begin{tabular}{|c|c|c|c|c|c|c|c|c|c|}
\hline النسبة & عدد & & & ف المعرفي & |كُويات () & & & المفاهيم & م \\
\hline المئوية & الأسئلة & تقويم & تركيب & تحليل & تطبيق & فهم & تذكر & الرئيسية & \\
\hline$\%$ ro & $1 \varepsilon$ & $r$ & - & $r$ & 1 & V & r & العلم & 1 \\
\hline$\%$ Yo & 1. & $T$ & $T$ & r & Y & $r$ & $r$ & التلفكير & Y \\
\hline $\begin{array}{l}1 V .0 \\
\%\end{array}$ & V & $T$ & 1 & $r$ & 1 & $T$ & 1 & التناقدير & $r$ \\
\hline $\begin{array}{c}\text { YY.O } \\
\%\end{array}$ & 9 & $r$ & 1 & $r$ & $r$ & - & 1 & الإبداعي & $\varepsilon$ \\
\hline$\% 1 \ldots$ & $\varepsilon$. & 7 & $r$ & 9 & 7 & 1. & 7 & جموع & \\
\hline & $\begin{array}{l}1 \ldots \\
\%\end{array}$ & $\begin{array}{l}10 \\
\%\end{array}$ & $\% v .0$ & $\%$ \%Y.० & $\% 10$ & $\%$ ro & $\% 10$ & المئوية & \\
\hline
\end{tabular}

ويذلك أمكن التوصل لعدد الأسئلة الخاصة بكل مفهوم من المفاهيم المتضمنة في وحدة "

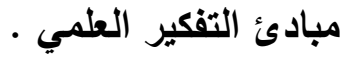

تعديد نوع مفردات الاختبار : حتى يكون الاختبار موضوعياً وشاملاً وأكثر قدرة علي قياس مدى نمو المفاهيم ، حدد الباحثان نوع مفردات الاختبار من ثلاثة أنواع من الأسئلة وهي :

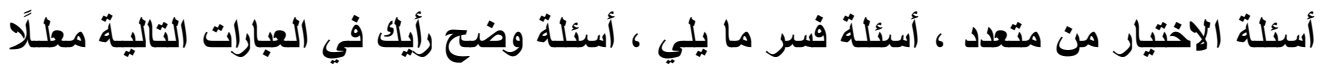
لما تقول.

صياغة مفردات الاختبار : لقد راعي الباحثان عند صياغة مفردات الاختبار أن تكون وفقًا (V)

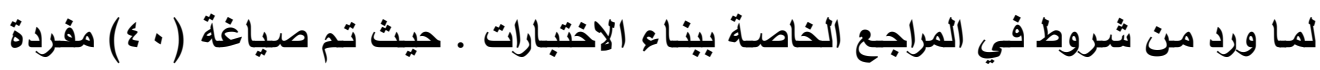
موزعة كالتالي : - مالي - المجال الأول : أسئلة الاختيار من متعدد ، وتتضمن المفردات من (1- ج ب) وتتظلب قيام الطالب بقراءة كل عبارة جيدا ،واختيار بديل واحد صحيح من بين البدائل الأربعة

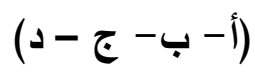

- المجال الثاني : أسئلة فسر ما يلي : وتتضمن المفردات من ( • - ع ب ) : وتتطلب قيام الطالب بتفسير بعض العبارات من خلال الكتابة على السطور الفارغة . - المجال الثالث : أسئلة وضح رأيك في العبارات التالية معلًا لما تقول: وتتضمن المفردات من (ه- - . ) ) : وتتطلب قيام الطالب بتحديد لأيه في بعض العبارات مع تعليل وتفسير هذا الرأي سواء كان بالسلب أو الإيجاب . 
ولقد تم توزيع مفردات الاختبار على المفاهيم المتضمنة في الوحدة ووفقا للمستويات المعرفية لتصنيف بلوم ، كما هو موضح بجدول (؛ ) ، كالتالي :

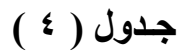

توزيع مفردات الاختبار على المستويات المعرفية للأهداف في اختبار المفاهيم

\begin{tabular}{|c|c|c|c|}
\hline 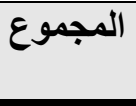 & أرقام المفردات في الاختبار & المستوية المعيات & b \\
\hline 7 & $r q 6 r \leqslant 619610696 V$ & التذكر & 1 \\
\hline 1. & 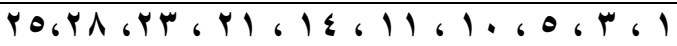 & الفهر & r \\
\hline 7 & $r \varepsilon, Y V_{6}, Y \cdot$, IV , IY ، $\varepsilon$ & التطبيق & $r$ \\
\hline 9 & 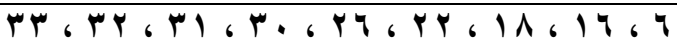 & التحليل & $\varepsilon$ \\
\hline$\mu$ & $T r \Lambda_{6} \Lambda_{6} r$ & التركيب & • \\
\hline 7 & 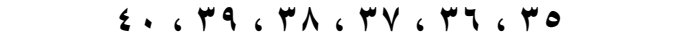 & التقويم & 7 \\
\hline
\end{tabular}

(^) تعليمات الاختبار: تم إعداد صفحة في مقدمة الاختبار تتناول التعليمات الموجهة للطلاب ، واستهدفت توضيح طبيعة الاختبار وكيفية الإجابة عنه ، ولقد راعي الباحثان أن تكون هذه هانه التعليمات واضحة ودقيقة بحيث يستطيع الطلاب من خلالها القيام بما هو مطلوب منهم

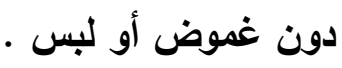
(9) الدراسة الاستطلاعية للاختبار : قام الباحثان بدراسة استطلاعية للاختبار إذ تم تجريبه على

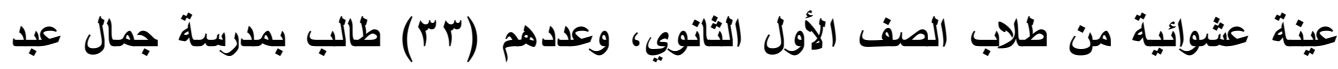

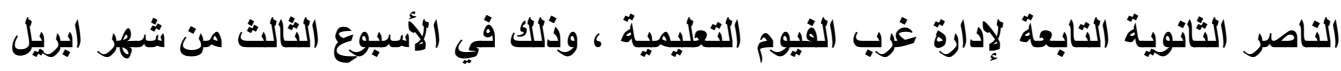
1 ـ ـ ، وذلك بعد التأكد من انتهاء الطلاب من دراسة " وحدة مبادئ التفكير العلمي " . وكان الهذف من هذه التجرية تحديد ما يلي: أ) ثبات الاختبار : تم الاعتمـاد في حسـاب معامل ثبات الاختبـار على طريقة تحليل التباين ، والتي تعني تعليل تباين درجات الطلاب على فقرات الاختبار ؛ و لذا تم حسـاب معـامل ثبـات الاختبار باستخدام معادلة كودر - ريتثاردسون • وقد بلغ (VV . • ) مما يذل علي أن الاختبار ذو ثبات عال . ب) صدق الاختبار : رغم تعدد أنواع الصدق ، إلا أنه تم الاعتماد في قياس صدق هذا الاختبار على نوعين فقط من هذه الأنواع وهما : - الصدق المنطقي : وذلك من خلال عرض المقياس على مجموعة من المحكمين لإبداء الرأي حول مدى مناسبة مفردات الاختبار للمستويات المعرفية والمفاهيم المتضمنة في من هندي 
الاختبار • ويعد إجراء التعديلات التي اقترحها المحكون ، اعتبر الاختبار صادقا من الناحية المنطقية .

- الصدق الذاتي: وهذا الصدق يقاس من خلال حساب الجذر التربيعى لمعامل الثبات. ويمـا أن معامل الثبات = VV . . فإن معامل الصدق الذاتي= ( ^^)،ويذلك يعد المقياس على درجة مناسبة من الصدق ماست

ج) معامل السهولة والصعوية للاختبار : لقد تم حساب معامل السهولة والصعوية من خلال نتائج تطبيق الاختبار على أفراد العينة وتم حساب معامل السهولة والصعوية لكل مفردة من مفردات الاختبار وفقاً للمعادلة التالية:

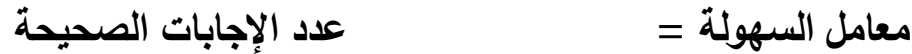

$$
\begin{aligned}
& \text { عدد الإجابات الصحيحة + عدد الإجابات الخاطئة }
\end{aligned}
$$

ويعد حساب معامل السهولة والصعوية لكل مفردة من مفردات الاختبار ، تم حساب معامل السهولة والصعوية للاختبار ككل ، حيث كان معامل السهولة ( ـه. . ) ، ومعامل الصعوية $\cdot(\cdot . \leqslant 7)$

د) زمن الاختبار : لقد اتبع الباحثان طريقة التسجيل التتابعي للزمن الذي استغرقه كل طالب

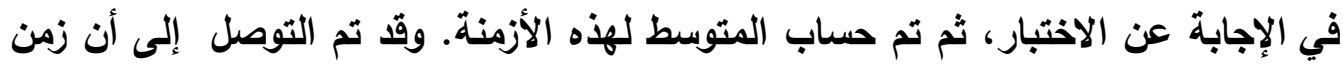

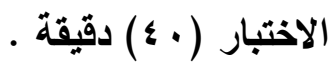

(•) (1) إعداد الصورة النهائية للاختبار : بعد الانتهاء من إعداد الاختبار ، وعرضه على في المحكمين ، وتعديله في ضوء مقترحاتهم وتعديلاتهم ، وحساب معاملات السهولة والصعوية ، وحساب معامل ثبات الاختبار ، والتأكد من صدقه أصبح الاختبار صالحاً للتطبيق ، وقد أشتمل الاختبار على (•؛ ) مفردة ، كما تحددت الدرجة النهائية وهي १ ( ) (

(11) تصحيح الاختبار : لقد اشتمل الاختبار على (·؛) مفردة ، وتم تصحيحها على النحو التالي : - المجال الأول : أسئلة الاختيار من متعدد : وعددها (9 (Y) مفردة ، وقد تم تخصيص درجة

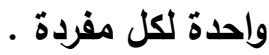


- المجال الثاني : أسئلة فسر ما يلي : وعددها (ه) مفردات ، وقد تم تخصيص درجة واحدة

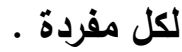

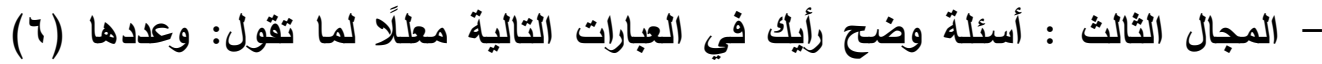
مفردات ، وقد تم تخصيص درجتين لكل مفردة ؛ حيث بأخذ الطالب درجة على إبداء أئه في العبارة ، ودرجة على تبرير وتعليل هذا الرأي." سادسا : إعلداد اختبار التفكير الإيجابي : وقد مر إعداده بالخطوات الآتية : (1) تحديد الهاف من الاختبار : يهدف الاختبار إلى قياس مدى اكتساب طلاب الصف الأول الأول

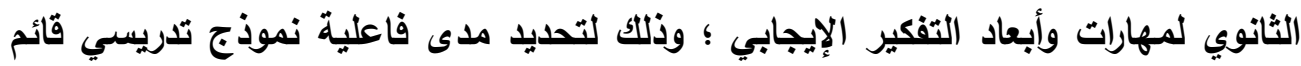
على نظرية الذكاء الناجح في تنمية مهارات التفكير الإيجابي لاى هؤلاء الطلاب .

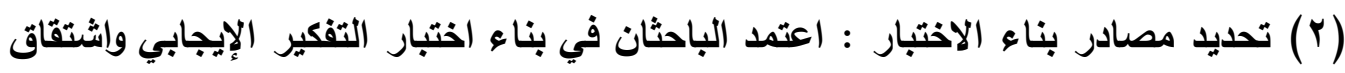
مادته على المصادر التالية : مالية • الاراسات والبحوث العربية والأجنبية التي تتاولت مهارات وأبعاد التفكير الإيجابي . • بعض الاختبارات التي صمت لقياس التفكير الإيجابي لاى طلاب المرحلة الثانوية . • بعض الأدبيات النظرية التي تناولت التفكير الإيجابي. • شبكة المعلومات الدولية والمصادر الرقمية . (ץ) أبعاد الاختبار: لقد اقتصر الاختبار على المهارات التي خلصت إليها القائمة النهائية لأبعاد

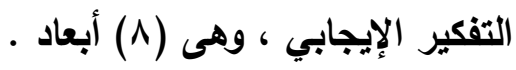
(؛) صياغة مفردات الاختبار : في ضوء المصادر السابقة تم صياغة مفردات الاختبار ، حيث تضمن الاختبار عرض مجموعة من النصوص التي تعبر عن قضايا اجتماعية وسياسية

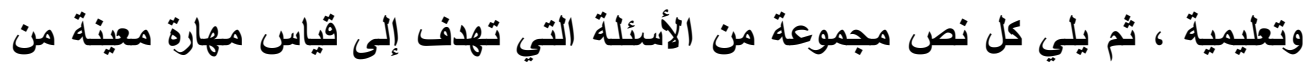
مهارات التفكير الإيجابي. حيث يقوم الطالب بالإجابة من خلال الكتابة على السطور الفارغة التي تلي كل مفردة ـ وجدول (ه) يتضمن توزيع مفردات الاختبار على أبعاد الإدابه

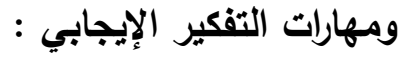

\footnotetext{
10 ملحق (^) : مفتاح تصحيح اختبار المفاهيم في وحدة " هبادئ التفكير العلمي ". 
استخدام نموذج مقترح قائم على نظرية الذكاء الناجح

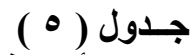

توزيع المفردات على المهارات والأبعاد في اختبار التفكير الإيجابي

\begin{tabular}{|c|c|c|c|}
\hline أرقام المفردات & عدد المفردات & أبعاد ومهارات التفكير الايجابي & م \\
\hline$r 0.1 V .960$ & $\varepsilon$ & الميل إلى التفاؤل والتوقع الايجابي & 1 \\
\hline$r \cdot, Y Y, I \leqslant 6 T$ & $\varepsilon$ & ضبط الانفعالات والتحكم في العمليات & r \\
\hline$\left.r \wedge, r \cdot, r_{r}\right) 1$ & $\varepsilon$ & تقبل المسئولية الثخصية & $r$ \\
\hline Y4،11,1.6؛ & $\varepsilon$ & منهاحظة الأفكار واستبعاد السلبي & $\varepsilon$ \\
\hline$r V .196116 r$ & $\varepsilon$ & للموضوع أو المشكلة الجاتب الايجابي & 0 \\
\hline$r q, r 1,1 r 6 r$ & $\varepsilon$ & الواقييزة بين الأهداف الواقعية وغير & 9 \\
\hline$r 16 r r 6106 V$ & $\varepsilon$ & تقبل الاختلاف عن الآخرين & $\mathrm{V}$ \\
\hline 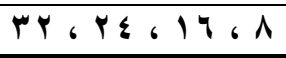 & $\varepsilon$ & الرغبة في المجازفة الايجابية & $\Lambda$ \\
\hline
\end{tabular}

(0) تعليمات الاختبار: تم إعداد صفحة في مقدمة الاختبار تتناول التعليمات الموجهة للطلاب، واستهذفت توضيح طبيعة الاختبار وكيفية الإجابة عنه ، ولقد راعي الباحثان أن تكون

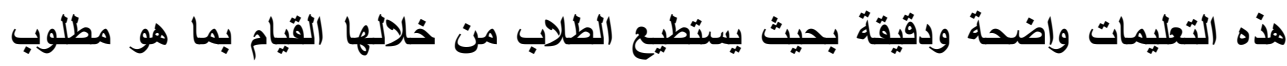

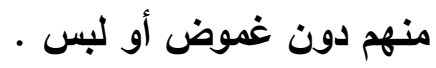

(7) عرض الاختبار في صورته المبائية على السادة المحكمين : بعد صياغة مفردات الاختبار ووضع التعليمات تم عرضه على مجموعة من المحكمين ؛ وذللك لإبداء الرأي حول مناسبة مفردات الاختبار والقضايا والنصوص الموضوعة لقياس مهارات وأبعاد التفكير الإيجابي ، وأيضا مناسبة عدد المفردات المحدة لقياس كل مهارة ، بالإضافة إلى السلامة اللغوية لمفردات الاختبار • وقد تم إجراء بعض التعديلات على صياغة بعض المواقف في ضوء ملاحظات السادة المحكمين . (V) الدراسة الاستطلاعية للاختبار : قام الباحثان بدراسة استطلاعية للاختبار ، إذ تم تجريبه على عينة عشوائية من طلاب الصف الأول الثانوي، وعددهم (rv) طالب بمدرسـة جمال بال عبد الناصر الثانويـة التابعة لإدارة غرب الفيوم التعليمية ، وذلك في الأسبوع الثاني من

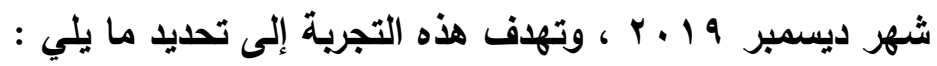

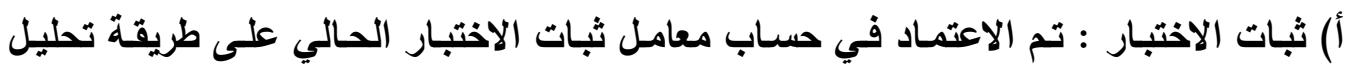

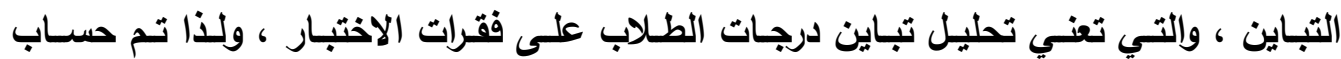


معامل ثبات الاختبار باستخدام معادلة كودر - ريتشاردسـون ـ وقد بلغ (ع V. · ) مما يلال

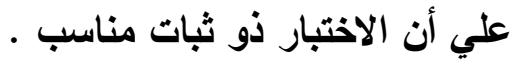
ب) صدق الاختبار : رغم تعدد أنواع الصدق ، إلا أنه تم الاعتماد في قياس صدق هذا هذا الاختبار على نوعين فقط من هذه الأنواع وهما : - الصدق المنطقي : وذلك من خلال عرض الاختبار على مجموعة من المحكمين لإبداء الرأي حول مدى مناسبة مفردات الاختبار لقياس أبعاد ومهارات التفكير الإيجابي. ويعد إجراء التعديلات التي اقترحها المحكمون ، اعتبر الاختبار صادقا من الناحية المنطقية . - الصدق الأاتي : وهذا الصدق يقاس من خلال حساب الجذر التربيعى لمعامل الثبات .

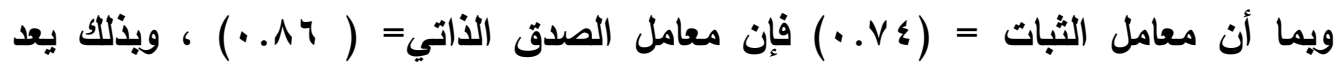
الاختبار على درجة مناسبة من الصدق .

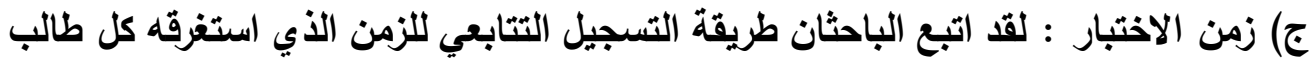

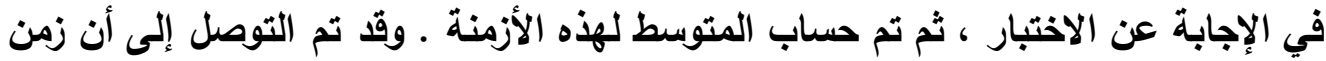
الاختبار (0 ؛ ) دقيقة.

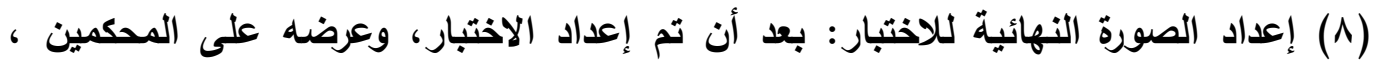

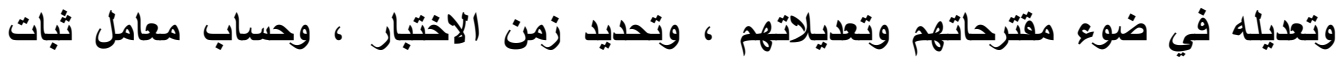

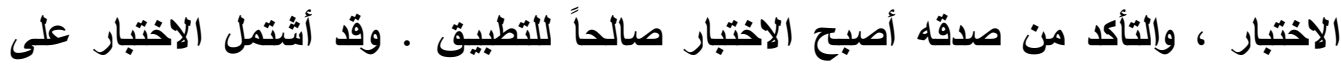

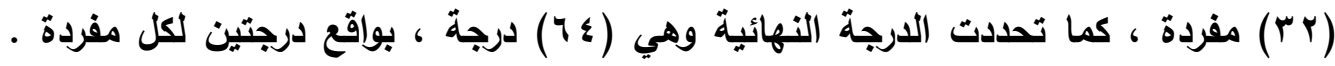
حيث أن اغلب المفردات تتطلب من الطالب إبداء الرأي بالقبول أو الرفض لعبارة معينة، ثم الثماته

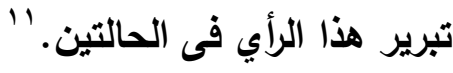

سابعا : إعلاد مقياس الاتجاهات العلمية :

تم التوصل إلى الصورة النهائية لمقياس الاتجاهات العلمية من خلال الخطوات التالية :

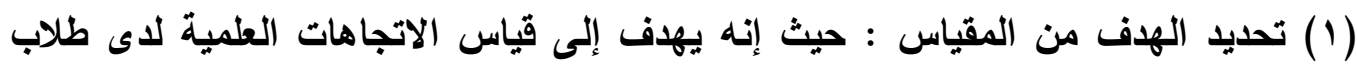
الصف الأول الثانوي ، وذلك للوقوف على مدى فاعلية نموذج تدريسي قائم على نظرية الذكاء الناجح في تنمية الاتجاهات العلمية لاى هؤلاء الطلاب . 
(Y) تحديد مصادر بناء المقياس: اعتمد الباحثان في بناء المقياس واشتتقاق مادته على المصادر التالية: - n

بعض الأدبيات النظرية المتعلقة بكيفية إعداد المقاييس .

موضوعات وحدة " مبادئ التفكير العلمي " فى كتاب مبادئ التفكير القلسفي والعلمي

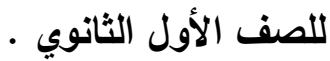

• بعض الاراسات والبحوث السابقة التي اهتمت بتنمية الاتجاهات العلمية.

• بعض المقاييس التي صممت لقياس الاتجاهات العلمية .

(r) تعديد أبعاد المقياس: بالنظر إلى المصادر السابقة والتصنيفات التي وضعت للأبعاد الخاصة بالاتجاه العلمي ، تم تحديد أبعاد مقياس الاتجاهات العلمية في خمسة أبعاد أساسية

هي كالتالي :

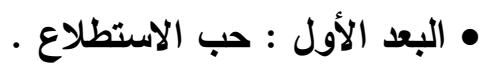

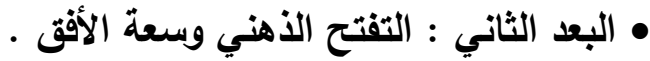

• البعد الثالث : الموضوعية .

• البعد الرابع : الأمانة العلمية .

• البعد الخامس : التروي والمثابرة .

( ) ) صياغة عبارات وينود المقياس: في ضوء المصادر السابقة ، وفى ضوء أبعاد المقياس

التي تم تحديدها في الخطوة السابقة ، ومع الوضع في الاعتبار خصائص الطلاب في سي

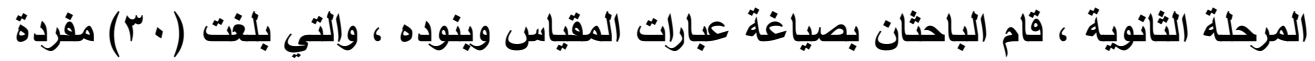
- بواقع ( آ) مفردات لكل بعد . وجدول (7) يتضمن توزيع مفردات المقياس على أبعاد

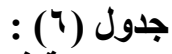

توزيع المفردات على الأبعاد الفرعية في مقياس الاتجاهات العلمية

\begin{tabular}{|c|c|c|c|}
\hline أرقام المفردات في المقياس & عدد المفردات & أبعاد الاتجاه العلمى & م \\
\hline Y96Y16196116761 & 7 & حب الاستطلاع & 1 \\
\hline$Y V_{6}, Y Y, I V, I Y, V_{6}, Y$ & 7 & التقتح الأهني وسعة الأفق & r \\
\hline$r \wedge, Y r, I \Lambda, I T, \Lambda, r$ & 7 & الموضوعية & $r$ \\
\hline$r q 6 r \leq 61961 \leq 696 \leq$ & 7 & الأمانة العلمية & $\varepsilon$ \\
\hline$r \cdot 6 r 0, Y \cdot 610,1,60$ & 7 & التروي والمثابرة & 0 \\
\hline
\end{tabular}


(0) صياغة تعليمات المقياس : تم إعداد صفحة في مقدمة المقياس تتناول التعليمات الموجهة للطلاب، والتي استهدفت توضيح طبيعة المقياس وكيفية الإجابة عنه ، وتحديد الزمن الكلي للمقياس.

(†) التجربة الاستطلاعية للمقياس : بعد عرض المقياس فى صورته المبدئية على بعض المحكمين وإجراء التعديلات التي اقترحها السادة المحكمون ، قام الباحثان بإجراء تجرية استطلاعية على المقياس. إذ تم تجريبه على عينة عشوائية من طلاب الصف الأول

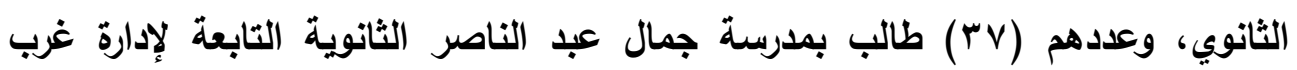

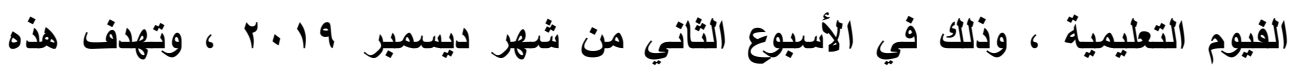

$$
\text { التجربة إلى تحديد ما يلي : }
$$

- حساب زمن المقياس : تم تحديد الزمن اللازم للإجابة عن مفردات المقياس من خلال استخدام طريقة التسجيل التتابعي للزمن الأي استغرقه كل طالب في الإجابة عن المقياس

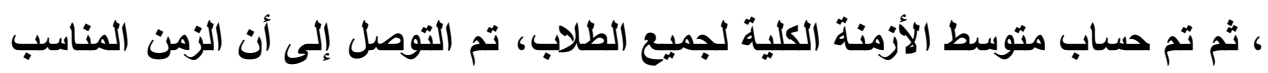

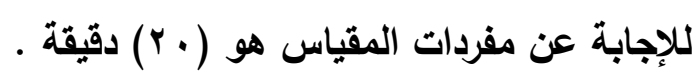

- التأكد من ثبات المقياس: تم الاعتماد في حساب معامل ثبات مقياس الاتجاهات العلمية

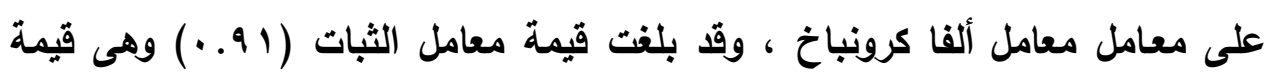

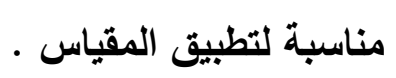

- التأكد من صدق المقياس : رغم تعدد أنواع الصدق ، إلا أنه اعتمد في قياس صدق هذاس :

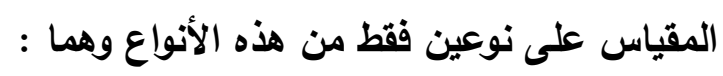
1- الصدق المنطقي : وذلك من خلال عرض المقياس على مجموعة من المحكمين لإبداء

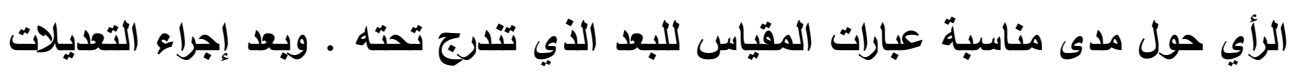
التي اقترحها المحكمون فيما يتعلق بصياغة عبارات المقياس اعتبر المقياس صادقا من

\section{الناحية المنطقية .}

ץ- الصدق الأتي : وهذا الصدق يقاس من خلال حساب الجذر التربيعى لمعامل الثبات .

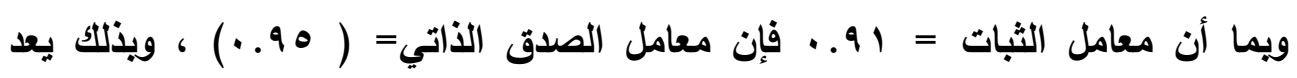
المقياس على درجة مناسبة من الصدق . 
(^) الصورة النهائية للمقياس : بعد إعداد المقياس وعرضه على السادة المحكمين وتعديله في ضوء مقترحاتهم وتعديلاتهم، ثم تجريته لحساب زمنه وإلتأكد من ثباته وصدقه أصبح المقياس صالح للتطبيق.

(9) تصحيح المقياس: اختار الباحثان طريقة ليكرت للتقديرات المتجمعة ذات الصورة الخماسية لتصحيح المقياس، وذلك للاستفادة من المزيا التي تتحقق باستخدامها ، وتعتمد تلك

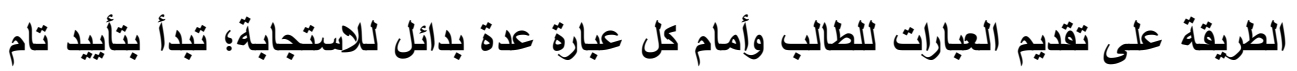

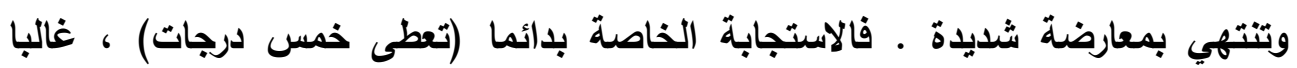

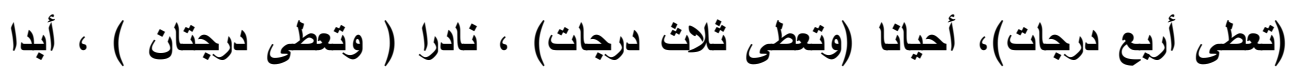

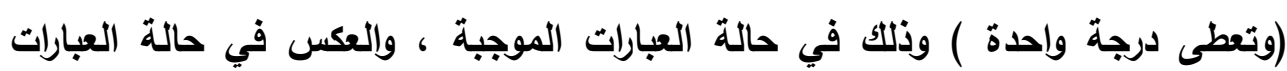

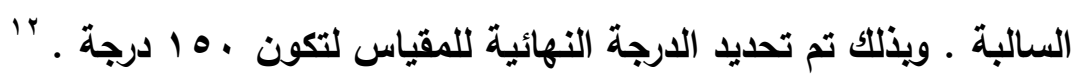

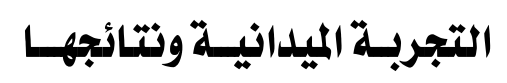

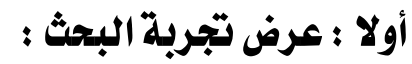
ا

يـهف إجراء تجرية البحث إلى قياس فاعلية استخدام نموذج تدريسي قائم على نظرية الأكاء الناجح في تدريس وحدة مبادئ التفكير العلمي على تنمية المفاهيم وإلتفكير الايجابي

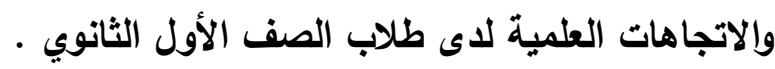
r المجتمع الإحصائي في هذا البحث هم طلاب الصف الأول الثانوي العام ، وعددهم (هـ)

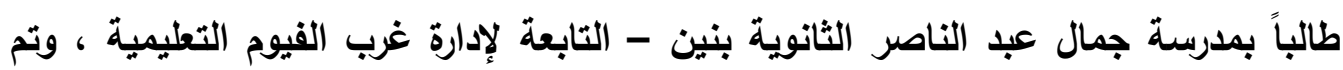

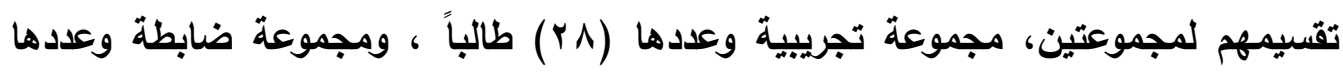
. طالباً (rv) r - متفيرات البحث : وتتضشن : أ - المتغيرات المستقلة : تتمثل المتفيرات المستقلة في هذا البحث في تدريس وحدة مبادئ التفكير العلمي المقررة على طلاب الصف الأول الثانوي باستخدام نموذج تدريسي قائم على 
نظرية الذكاء الناجح لطلاب المجموعة التجريبية ، وتدريس نفس الوحدة بالطريقة المعتادة لطلاب المجموعة الضابطة . ل ب - المتغيرات التابعة : تتمثل المتغيرات التابعة في هذا البحث فى: تنمية المفاهيم والتفكير الايجابي والاتجاهات العلمية لدى طلاب الصف الأول الثانوي.

$$
\text { ج - المتغيرات الوسيطة: وتتمثل في : }
$$

1 - العمر الزمني : بلغ متوسط أعمار الطلاب عينة البحث - المجموعة التجريبية والضابطة -

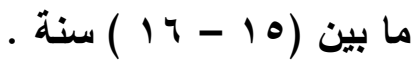

r- المستوى الاجتماعي والاقتصادي : تم اختيار عينة المجموعة التجريبية والضابطة من نفس المدرسة أى : من بيئة اقتصادية واجتماعية تكاد تكون متقارية . r- طبيعة المادة الدراسية : التزم الباحثان بما جاء من محتوى في وحدة مبادئ التفكير العلمي المتضمنة في كتاب مبادئ التفكير الفلسفي والعلمي المقرر على طلاب الصف الأول

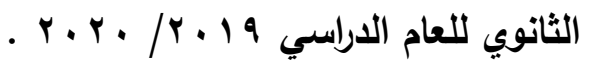

ع - مستوى المفاهيم والتفكير الإيجابي والاتجاهات العلمية لاى الطلاب : تم تطبيق أدوات البحث التي تم إعدادها وهى:اختبار المفاهيم ، وإختبار التفكير الإيجابي ، ومقياس الاتجاهات العلمية قبل إجراء التجرية تطبيقًا قبليًا على كل من طلاب المجموعتين التجريبية والضابطة ، وتم رصد درجات المجموعتين ، ومعالجتها إحصائيا. وتتلخص نتائج المعالجة في جدول (V) كالتالي :

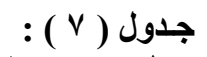

\begin{tabular}{|c|c|c|c|c|c|c|c|c|c|}
\hline مستوي & قيمة(ت) & بدولية & & درجة & الضابطة & المجمو= & |تجريبية & المجمو= & $\pi$ \\
\hline لإحصائية & & 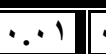 & .0 & & $\varepsilon$ & م & $\varepsilon$ & م & \\
\hline غير دالة & $1 . .4$ & ץ.77 & r & & r.०V & $\Lambda . \vee 4$ & r.T. & $9.0 \mathrm{~V}$ & المفاهيم \\
\hline غير دالة & 1.97 & & & or & $\varepsilon$ & 11.09 & r.o. & 19.11 & |اختبار التفكير \\
\hline غير دالة & 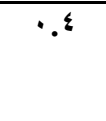 & & & & $1 . . r r$ & $09.4 \%$ & $1.0 r$ & $4 \cdot . \mathrm{Vr}$ & الاتجاهيةت \\
\hline
\end{tabular}
قيمة (ت) ودلالتها الإحصائية للفرق بين متوسطي درجات المجمو عتين التجريبية والضابطة في التطبيق

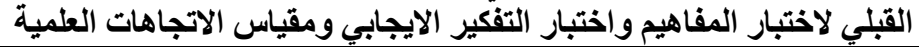


ويتضح من جدول (V) : أن المستوى المبئي لطلاب المجموعتين التجريبية والضابطة في المفاهيم ، والتفكير الإيجابي ، الاتجاهات العلمية متكافئ · بمغنى أنه يوجد تجانس بين أفراد المجموعتين ، حيث إن الفرق بين متوسطي درجات المجموعتين في التطبيق القبلي

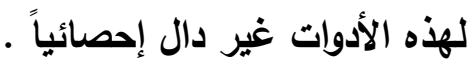
ه- القائم بعملية التدريس : تم التتريس للمجموعتين بواسطة معلم الفصل ، أي أن المعلم الذي قام بالتدريس للمجموعة التجريبية هو نفسه الذي قام بالتدريس للمجموعة الضابطة . ثانيا : إجراء تجربة البحث : سارت إجراءات تجرية البحث وفقا للخطوات الآتية : 1- التطبيق القبلي لأدوات البحث : حيث تم تطبيق اختبار المفاهيم ، واختبار التفكير الإيجابي ، ومقياس الاتجاهات العلمية على الطلاب عينة البحث قبليا ، وذلك في

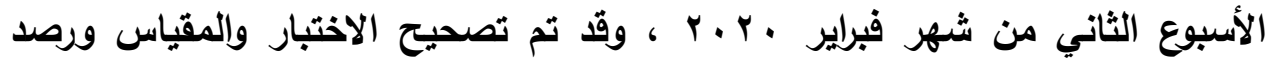

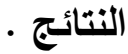
r- تدريس الوحدة المختارة : بعد الانتهاء من عملية التطبيق القبلي لأدوات البحث، تم تدريس وحدة مبادئ التفكير العلمي المقرة على طلاب الصف الأول الثانوي خلال الفصل الدراسي الثاني ، وذلك باستخذام النموذج المقترح - القائم على نظرية الذكاء

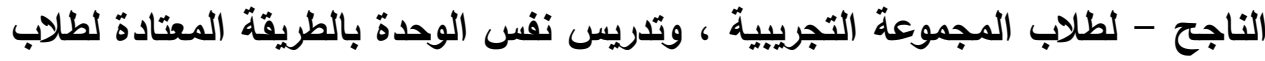
المجموعة الضابطة ، وقد تم تطبيق الموضوع الأول للوحدة (معنى العلم وأخلاقيات العالم) والموضوع الثاني (خصائص التفكير العلمي وخطواته) بمدرسة التطبيق وداخل

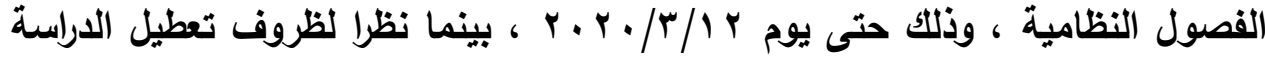
بالمدارس - بسبب جائحة كورونا - تم تطبيق الموضوع الثالث للوحدة (التفكير الناقد والتفكير الإبداعي) نظام التعليم عن بعد (أون لاين) ، وذلك من خلال معلم الفصل بعد أخذ الموافقات الرسمية على هذا النوع من التطبيق - حيث قام التهام معلم الفصل بإنشاء جروب خاص لطلاب المجموعة التجريبية على موقع التواصل الاجتماعي (الفيس بوك)

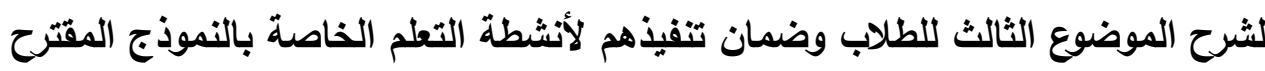
، بينما كان معلم الفصل يتواصل من خلال جروب آخر يضم باقي فصول الصف الأول الثانوي بالمدرسة - ومنهم طلاب المجموعة الضابطة ـ وعلى الرغم من المشاكل التي 
تظهرها طرق التعليم عن بعد في عملية التدريس ، إلا أن الباحثان استكملا التطبيق بهذه الطريقة بعد التأكد من تفاعل أكثر من • V \% من طلاب المجموعتين التجريبية والضابطة وإنتظامهم في متابعة الدروس من خلال مجموعات التواصل الاكتروني . وأيضا تحقيقا للأمانة والموضوعية العلمية قام الباحثان باستعباد الطلاب الذين لم يتفاعلوا بشكل جيد أثناء شرح الدروس أون لاين ، وذلك على مستوى المجموعتين التجريبية والضابطة . حيث أن عدد طلاب المجموعة التجريبية بالمدرسة في بداية التطبيق كان (جq) طالبا ، والمجموعة الضابطة كان (• ع ) طالبا ـ ثم بعد استبعاد الطلاب غير المشاركين بفاعلية في التطبيق الاكتروني أصبحت المجموعة التجريبية

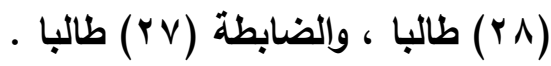

r- التطبيق البعدى لأدوات البحث: فبعد الاتتهاء من تدريس وحدة مبادئ التفكير العلمي للمجموعتين التجريبية والضابطة، تم إعداد نسخة الكترونية على Google Drive من لإنى اختبار المفاهيم ، وإختبار التفكير الإيجابي ، ومقياس الاتجاهات العلمية ، وتم إتاحة الأدوات الثلاثة لطلاب المجموعتين التجريبية والضابطة للإجابة عنها بشكل الكتروني ، الإبية ،

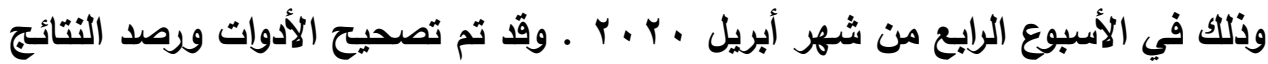

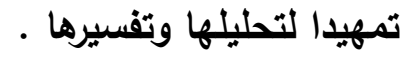

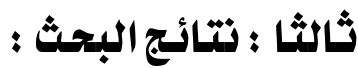
استعان الباحثان في المعالجة الإحصائية للبيانات بالحزمة الإحصائية (SPSS-V23) ، وقد تضمنت نتائج البحث ما يلي : ا - نتائج تطبيق اختبار المفاهيم في وحدة " مبادئ التفكير العلمي " . r- نتائج تطبيق اختبار التفكير الايجابي • r- بتائج تطبيق مقياس الاتجاهات العلمية . وسوف يتم عرض النتائج من خلال اختبار صحة الفروض وتفسير نتائج البحث . 1) اختبار صحة الفرض الأول للبحث : بالنسبة للفرض الأول من فروض البحث والأي نص على ما يلي : " توجد فروق ذات دلالة إحصائية بين متوسطي درجات طلاب المجموعتين التجريبية والضابطة في التطبيق البعدي لاختبار المفاهيم لصالح المجموعة التجريبية" . 
ولاختبار صحة هذا الفرض تم استخدام اختبـار "ت" لعينتين مستقتثين Independent) Sample T-test) الفروق بين متوستِطات درجات طلاب المجموعتين التجرينيَّة والضسابطة في التطبيق البَعدي لاختبار المفاهيم ، وجدول (^) يوضِّح هذه النتائج:

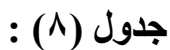

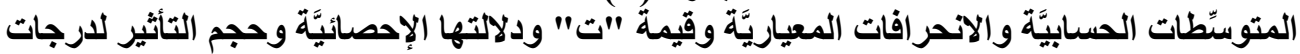

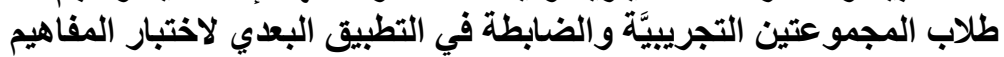

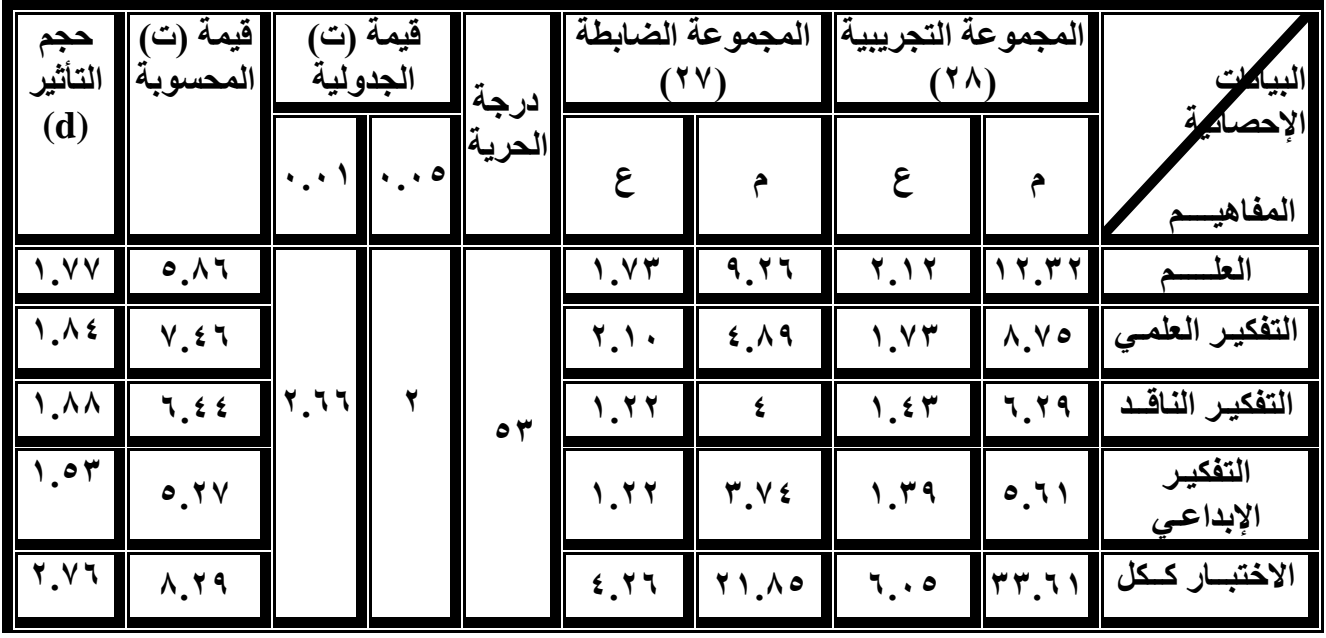

ويتضح من جدول (^) ما يلي :

• ارتفاع متوسط درجات طلاب المجموعة التجريبية عن متوسط درجات طلاب المجموعة الضابطة فى التطبيث البعدي لمفهوم (العلم).حيث بلغ متوسط درجاث طلاب المجموعة

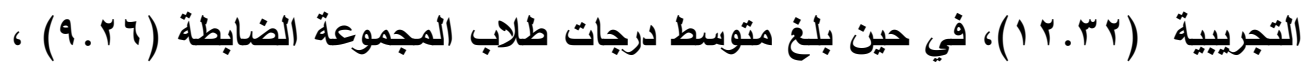
ويلغت قيمة (ت) المحسوية (؟ ^.0) ، وقيمة (ت) الجدولية تساوي (Y) عند مستوى ثقة

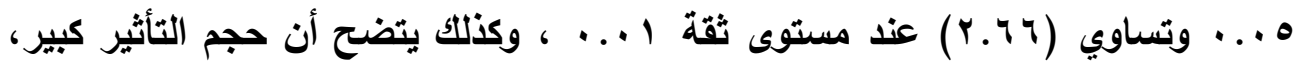

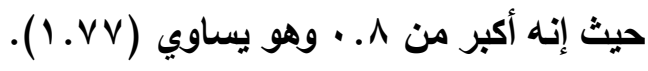

وممـا سـبق يتضـح أن قيمـة "ت" المحسـوية أكبر بكثير مـن قيمـة "ت" الجدوليـة عند مستوى ه . . . ، ومستوى 1 . . . ، مما يدل على وجود فرق دال إحصائيا لصسالح طلاب

$$
\text { المجموعة التجريبية في هذا المفهوم • }
$$

• ارتفاع متوسط درجات طلاب المجموعة التجريبية عن متوسط درجات طلاب المجموعة الضابطة في التطبيق البعدي لمفهوم (التفكير العلمي).حيث بلغ متوسط درجات طلاب 
المجموعة التجريبية (A.V0)، في حين بلغ متوسط درجات طلاب المجموعة الضابطة

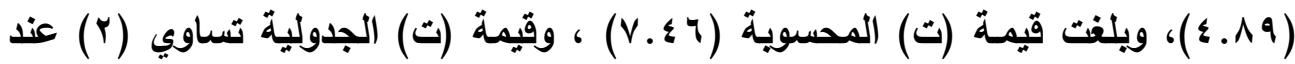
مستوى ثقة ه...

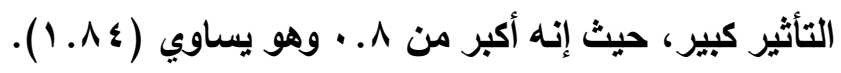

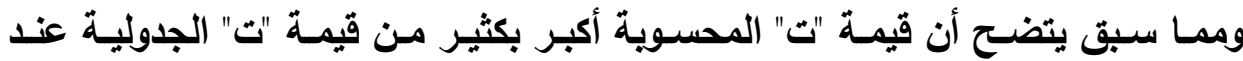
مستوى ه. .. . ، ومستوى ا ... ، مما يدل على وجود فرق دال إحصائيا لصالح طلاب المجموعة التجريبية في هذا المفهوم . • ارتفاع متوسط درجات طلاب المجموعة التجريبية عن متوسط درجات طلاب المجموعة الضابطة فى التطبيق البعدي لمفهوم (التفكير الناقد). حيث بلغ متوسط درجات طلاب

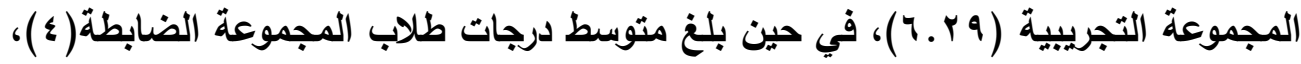

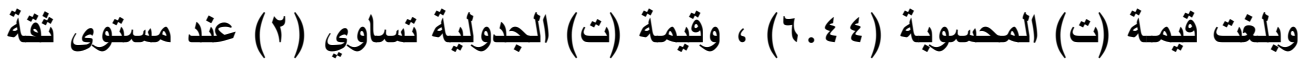

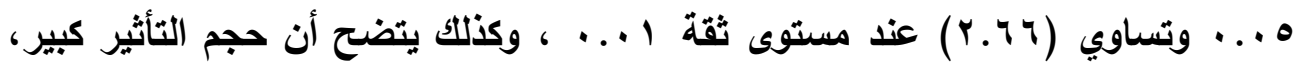

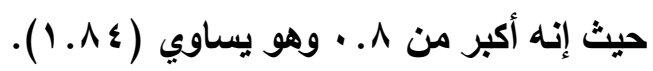

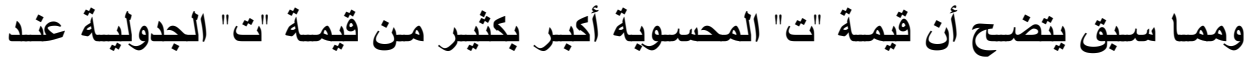
مستوى ه. .. . ومستوى ا ... ، مما يدل على وجود فرق دال إحصائيا لصالح طلاب

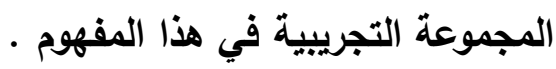
• ارتفاع متوسط درجات طلاب المجموعة التجريبية عن متوسط درجات طلاب المجموعة الضابطة فى التطبيق البعدي لمفهوم (التفكير الإبداعي). حيث بلغ متوسط درجات طلاب المجموعة التجريبية (9 Y.7)، في حين بلغ متوسط درجات طلاب المجموعة الضابطة

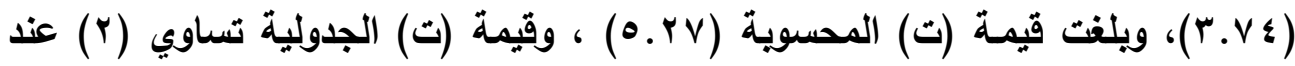
مستوى ثقة ه...

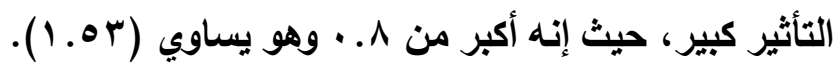

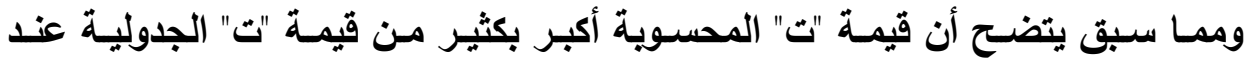
مستوى ه .. . ، ومستوى ا ... . ممـا يدل على وجود فرق دال إحصائيا لصـالح طلاب المجموعة التجريبية في هذا المفهوم . 
• ارتفاع متوسط درجات طلاب المجموعة التجريبية عن متوسط درجات طلاب المجموعة الضابطة فى التطبيق البعدي(لاختبار المفاهيم ككل) ـ حيث بلغ متوسط درجات طلاب

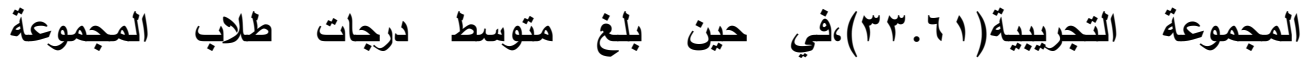

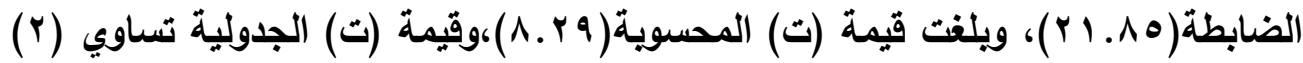

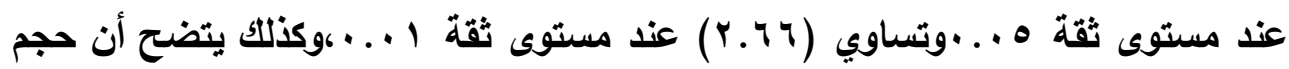

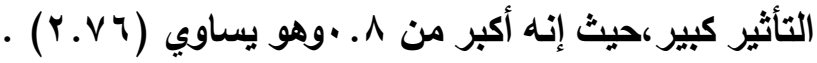
ومما سبق يتضح أن قيمة "ت" المحسوية أكبر بكثير من قيمة "ت" الجدولية عند مستوى ه ... ، ومستوى 1 .. . . ، مما يدل على وجود فرق دال إحصائيا لصالح طلاب المجموعة التجريبية في الاختبار ككل . مهنوي ومسن النتـائج السـابقة يتضـح أن هنـاك فـروق ذات دلالـة إحصـائية لصـالح طـلاب المجموعة التجريبية فى التطبيق البعدى لاختبار المفاهيم في كل مفهوم على حده ، وفى الاختبار ككل ؛ مما يؤدى إلى قبول صحة القرض الأول للبحث .

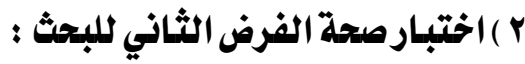
بالنسبة للفرض الثاني من فروض البحث والذي نص على ما يلي :

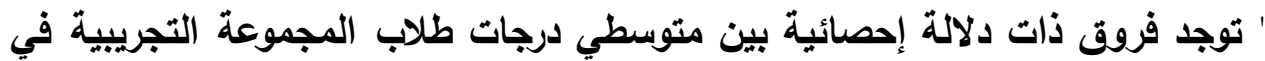
التطبيقين القبلي والبعدى لاختبار المفاهيم لصالح التطبيق البعدى " . ولاختبار صحة هذا الفرض تم استخدام اختبار "ت" لعينتين مرتبطتين Paired Sample) (T-test) بين متوسطات درجـات طلاب المجموعة التجريبيـة في التطبيقين القبلى والبعدى لاختبار

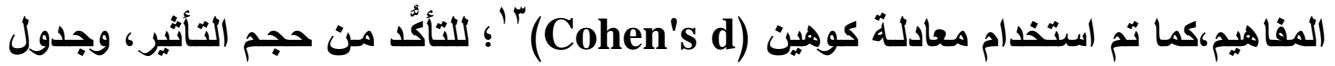
(9) : يوضح ذلك

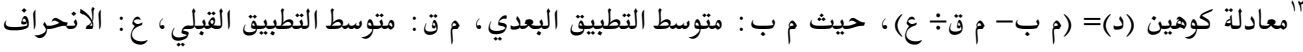

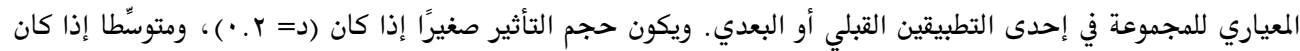

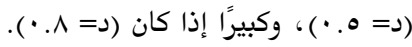




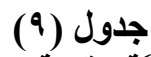

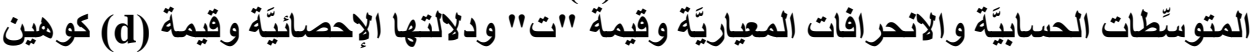

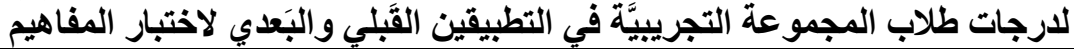

\begin{tabular}{|c|c|c|c|c|c|c|c|c|c|}
\hline \begin{tabular}{|c|} 
(d) \\
\\
\\
\end{tabular} & قالمحسوبية) & \multicolumn{2}{|c|}{ قالجدةولية } & الحرية & \multicolumn{2}{|c|}{ التطبيق البعدى } & \multicolumn{2}{|c|}{ التطبيق القبلي } & 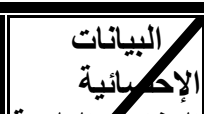 \\
\hline 0.74 & $r \cdot . V 0$ & \multirow{5}{*}{ r.v. } & \multirow{5}{*}{ r.r } & \multirow{5}{*}{ TV } & $\overline{r .1 Y}$ & $\overline{I Y . Y Y}$ & 1.09 & $r . r 9$ & العلـــــ \\
\hline$\Lambda . \Upsilon \wedge$ & $Y \cdot . V \varepsilon$ & & & & $1 . V r$ & A.Vo & $\cdot . \wedge 0$ & $1 . v 1$ & فكير العلمسي \\
\hline 0.01 & 11.91 & & & & $1 . \varepsilon r$ & 7.19 &..$V Y$ & $\overline{Y . Y Y}$ & التفكير الناقــــا \\
\hline $7.1 \varepsilon$ & Ir.Or & & & & $1 . r 9$ & 0.71 &. $.0 \mathrm{~V}$ & r.11 & الالتباعير \\
\hline $1 \cdot . \leqslant 0$ & $r \cdot .04$ & & & & $9 . .0$ & TY.T & Y.r. & $9.0 \mathrm{~V}$ & الاختبــار كـكل \\
\hline
\end{tabular}

ويتضح من جدول (9) : وجود فروق ذات دلالة إحصائَّة-عند مستوى عند مستوى ه ... ، ومستوى ا ... . . بين متوسيّطات درجات طلاب المجموعة التجريبيَّة في التطبيقين القَبلي والبَعدي لاختبار المفاهيم ، في الاختبار ككل ، وفى كل مفهوم على حده ، وذلك

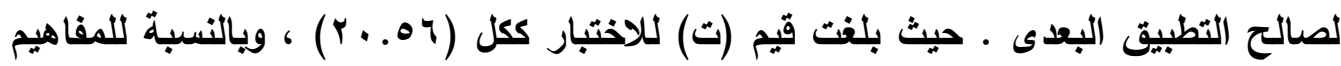
المتضمنة في الاختبار وهى : ( العلم ، التفكير العلمي ، التفكير الناقد ، التفكير الإبداعي )

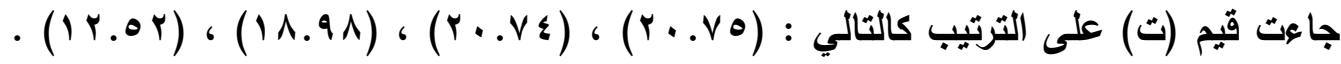

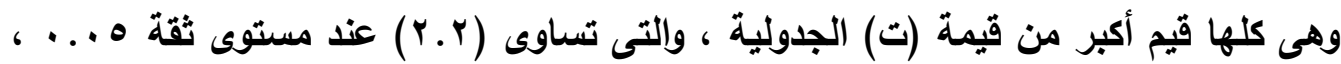

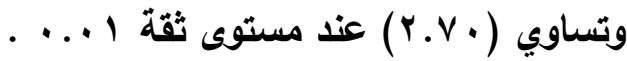
كما يتَّضح من جدول (9) : أن قيم (d) كوهين في اختبار المفاهيم ككل (0 ؛ . 1)،

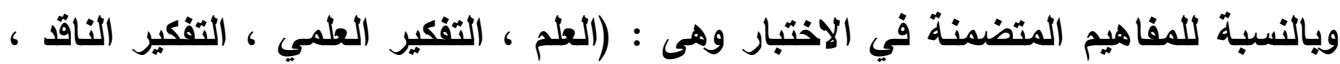

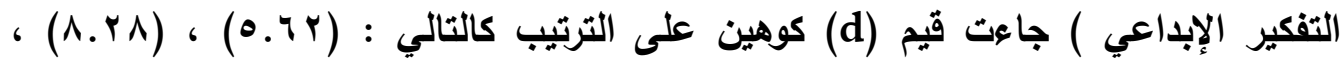

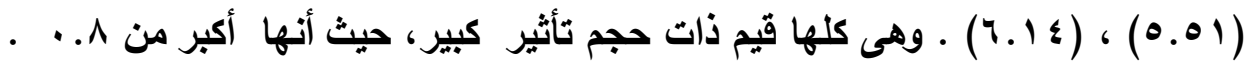
ومن النتائج السابقة يتضح أن هناك فروق ذات دلالة إحصائية بين متوسطي درجات طلاب المجموعة التجريبية في التطبيقين القبلى والبعدى لاختبار المفاهيم لصالح التطبيق البعدى ، وذلك في الاختبار ككل ، وفى كل مفهوم على حده ؛ مما يؤدى إلى قبول صحة

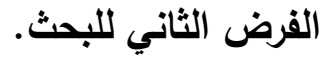


استخدام نموذج مقترح قائم على نظرية الذكاء الناجح

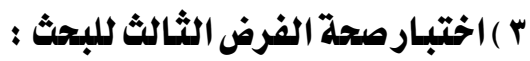

بالنسبة للفرض الثالث من فروض البحث والذي نص على ما يلـي : " توجد فروق ذات

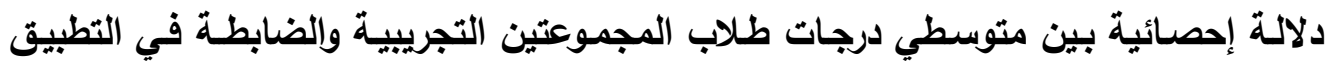
البعدي لاختبار التفكير الإيجابي لصالح المجموعة التجريبية" .

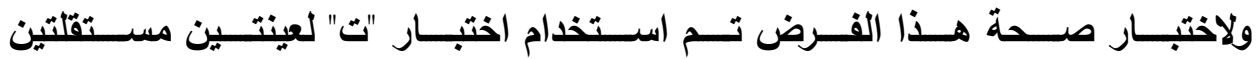
(Independent Sample T-test) المعياريَّة، وقيمـة (ت) لالالـة الفروق بين متوستّطات درجـات طلاب المجموعتين التجريبَّة والضابطة في التطبيق البَعدي لاختبار التفكير الإيجابي ، وجدول ( • 1) يوضِّح هذه النتائج:

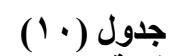

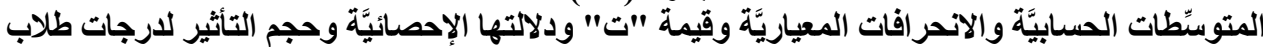

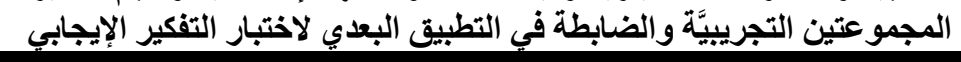

\begin{tabular}{|c|c|c|c|c|c|c|c|c|}
\hline حجم التأثير & المحسوبة & قاليمة (ت) & الدرية & \multicolumn{2}{|c|}{ |المجموعة الضابطة } & \multicolumn{2}{|c|}{ المجموعة التجريبية } & هصائية \\
\hline 1.1 & $\varepsilon$ & & & $1 . r 9$ & r.o. & 1.59 & ๕.97 & والتيل إلى التفاؤل \\
\hline $1 . \leqslant 9$ & 0.74 & $r 77$ & & $1 . r 9$ & T.YT & $1 . r V$ & 0.19 & والتحكي في الانفعلاتيات \\
\hline 1.70 & 0.04 & & & 1.4 & r.IT & 1.00 & ¿.Ar & تقبل المسئولية \\
\hline 9.94 & $\varepsilon . \wedge \varepsilon$ & & & $1 . \leqslant r$ & r.11 & .90 & & ماستبعاد السلبي \\
\hline I.YY & \&.^. & & or & $1 . \leqslant r$ & T.IT & $1 . r \leqslant$ & ؟.人 & الايجابي للموضلى الجانب \\
\hline 1.09 & צ. & & & .91 & r.A & $1 . \varepsilon r$ & צ & |التمييز بين الأهدافي \\
\hline$\overline{r . \wedge r}$ & 9.71 & & & $\cdot . \wedge v$ & r.. \& & 1 & 0.0. & تقبل الاختّلاف عن \\
\hline 1.14 & T. T. & & & $\because v V$ & $r . r V$ & $1 . .8$ & r. Is & الرغبة في المجازفة \\
\hline r.६ & 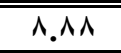 & & & 0.0. & $r \leqslant .19$ & $0 . \xi Y$ & rv.rq & الاختبار ككل \\
\hline
\end{tabular}




$$
\text { ويتضح من جدول ( · ) ما يلي : }
$$

• ارتفاع متوسط درجات طلاب المجموعة التجريبية عن متوسط درجات طلاب المجموعة الضابطة في التطبيق البعدي لبعد التفكير الإيجابي الخاص بـ (الميل إلى التفاؤل والتوقع

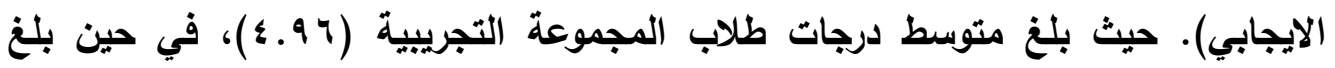

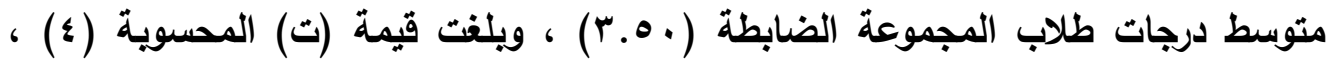

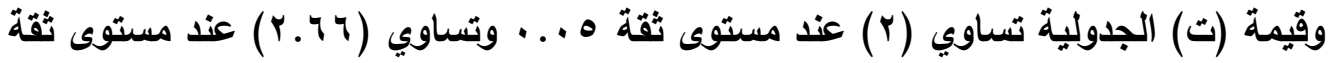

1 . . . ، وكذلك يتضح أن حجم التأثير كبير، حيث إنه أكبر من ^. . وهو يساوي (1. (1).

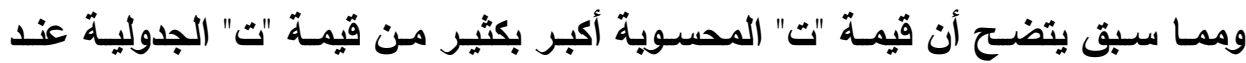
مستوى ه. .. . ، ومستوى ا ... ، مما يدل على وجود فرق دال إحصائيا لصـالح طلاب

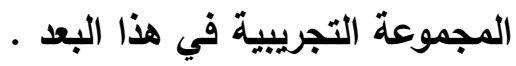
• ارتفاع متوسط درجات طلاب المجموعة التجريبية عن متوسط درجات طلاب المجموعة الضابطة في التطبيق البعدي لبعد التفكير الإيجابي الخاص بـ(ضبط الانفعالات والتحكم في

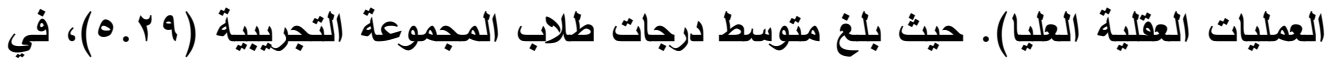
حين بلغ متوسط درجات طلاب المجموعة الضابطة (ب.r.Y) ، ويلغت قيمة (ت) المحسوية

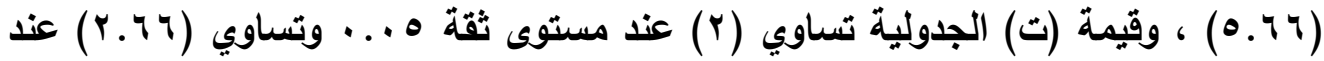
مستوى ثقة ا ... ، وكذلك يتضح أن حجم التأثير كبير، حيث إنه أكبر من ^. . . وهو يساوي

وممــا سـبق يتضـح أن قيمـة "ت" المسـوية أكبر بكثير مـن قيمـة "ت" الجدوليـة عنـــ مستوى ه. .. ، ومستوى ا .. . ، مما يدل على وجود فرق دال إحصائيا لصـالح طلاب المجموعة التجريبية في هذا البعد . • ارتفاع متوسط درجات طلاب المجموعة التجريبية عن متوسط درجات طلاب المجموعة الضابطة في التطبيق البعدي لبعد التفكير الإيجابي الخاص بـ(تقبل المسئولية الشخصية).

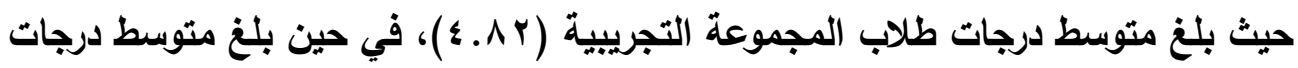

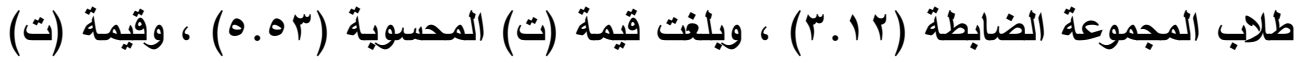

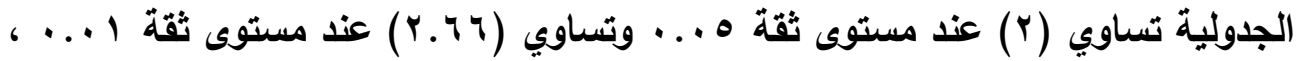

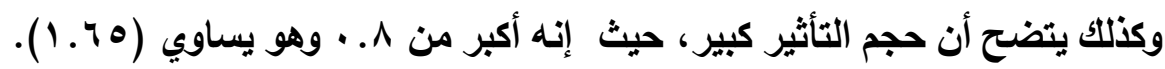




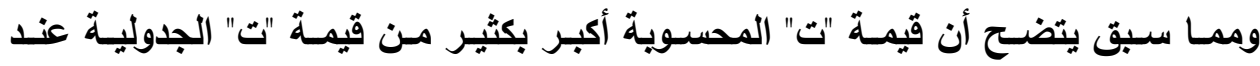
مستوى ه. .. ، ومستوى ا .. . ، مما يدل على وجود فرق دال إحصائيا لصالح طلاب

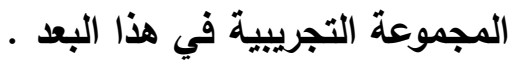
• ارتفاع متوسط درجات طلاب المجموعة التجريبية عن متوسط درجات طلاب المجموعة الضابطة في التطبيق البعدي لبعد التفكير الإيجابي الخاص بـ(ملاحظة الأفكار واستبعاد

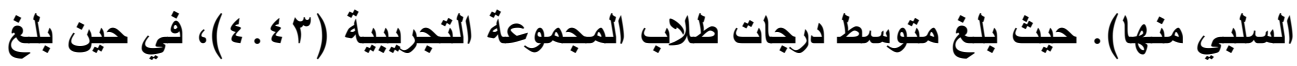
متوسط درجات طلاب المجموعة الضابطة (1 1 ــ)،ويلغت قيمة (ت) المحسوية (ع ^. ؛ )،

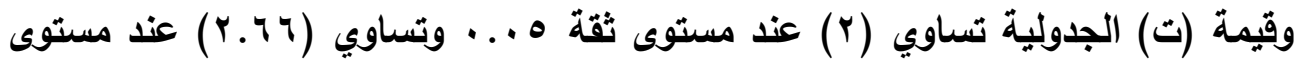

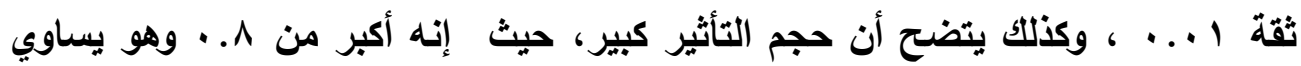
$\cdot(\cdot .9 r)$

وممــا سبق يتضـح أن قيمـة "ت" المحسوية أكبر بكثير مـن قيمـة "ت" الجدوليـة عنـــ

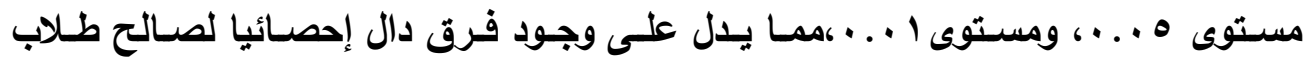
المجموعة التجريبية في هذا البعد. • ارتفاع متوسط درجات طلاب المجموعة التجريبية عن متوسط درجات طلاب المجموعة الضابطة في التطبيق البعدي لبعد التفكير الإيجابي الخاص بـ(التركيز على الجانب الايجابي للموضوع أو المشكلة). حيث بلغ متوسط درجات طلاب المجموعة التجريبية

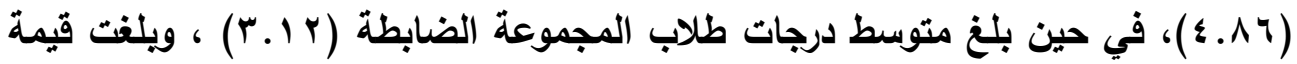

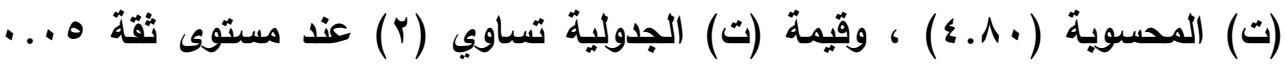

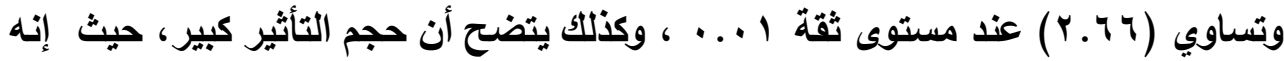

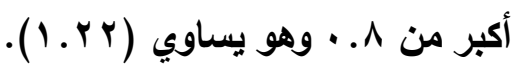

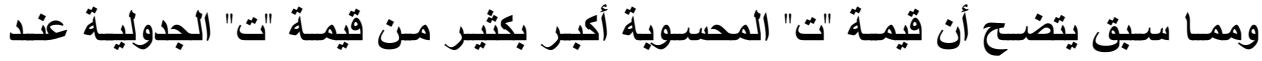
مستوى ه .. . ، ومستوى ا .. . ، مما يدل على وجود فرق دال إحصائيا لصالح طلاب المجموعة التجريبية في هذا البعد .

• ارتفاع متوسط درجات طلاب المجموعة التجريبية عن متوسط درجات طلاب المجموعة الضابطة في التطبيق البعدي لبعد التفكير الإيجابي الخاص بـ(التمييز بين الأهداف الواقعية وغير الواقعية). حيث بلغ متوسط درجات طلاب المجموعة التجريبية ( آ. ؛)، في حين 
بلغ متوسط درجات طلاب المجموعة الضابطة (1 (Y. Y) ، ويلغت قيمة (ت) المحسوية

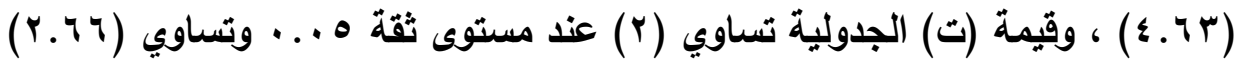
عند مستوى ثقة ا ... . . وكذلك يتضح أن حجم التأثير كبير، حيث إنه أكبر من ^. . . وهو يساوي (1.09). (1.09).

وممــــــق يتضـح أن قيمـة "ت" المحسوية أكبر بكثير مـن قيمـة "ت" الجدوليـة عنـــ مستوى ه. .. . ، ومستوى ا ... ، . مما يدل على وجود فرق دال إحصائيا لصالح طلاب المجموعة التجريبية في هذا البعد . • ارتفاع متوسط درجات طلاب المجموعة التجريبية عن متوسط درجات طلاب المجموعة الضابطة في التطبيق البعدي لبعد التفكير الإيجابي الخاص بـ( تقبل الاختلاف عن

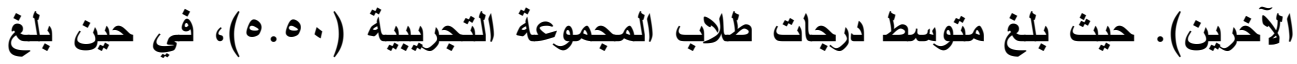

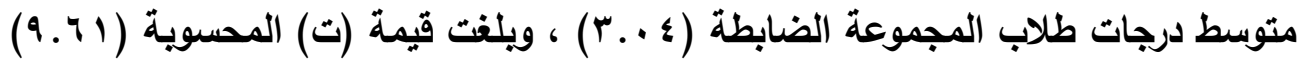

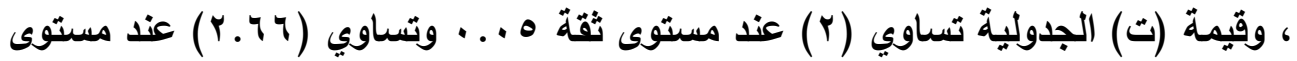
تقة ا ب. . . ، وكذلك يتضح أن حجم التأثير كبير، حيث إنه أكبر من ^. . . وهو يساوي $\cdot(Y . \wedge T)$

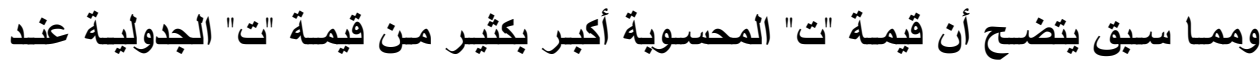
مستوى ه. .. . ، ومستوى ا ... ، مما يدل على وجود فرق دال إحصائيا لصـالح طلاب المجموعة التجريبية في هذا البعد . • ارتفاع متوسط درجات طلاب المجموعة التجريبية عن متوسط درجات طلاب المجموعة الضابطة في التطبيق البعدي لبعد التفكير الإيجابي الخاص بـ(الرغبة في المجازفة

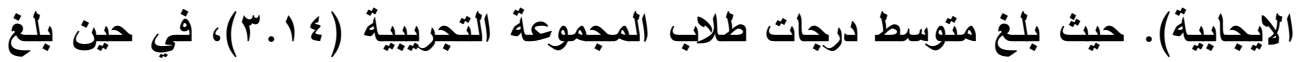

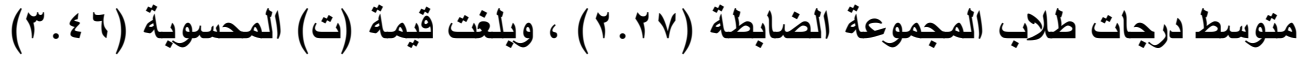

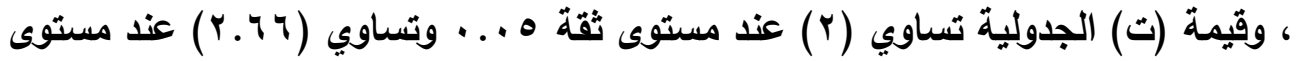
ثقة ا +... ، وكذلك يتضح أن حجم التأثير كبير، حيث إنه أكبر من ^. . . وهو يساوي 


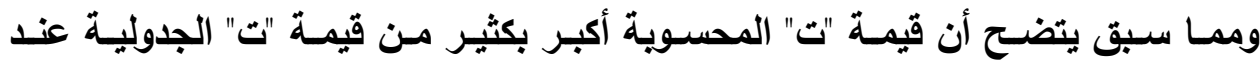
مستوى ه. .. . ومستوى ا ... ، مما يدل على وجود فرق دال إحصائيا لصالح طلاب

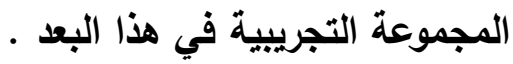
• ارتفاع متوسط درجات طلاب المجموعة التجريبية عن متوسط درجات طلاب المجموعة الضابطة فى التطبيق البعدي (لاختبار التفكير الإيجابي ككل). حيث بلغ متوسط درجات

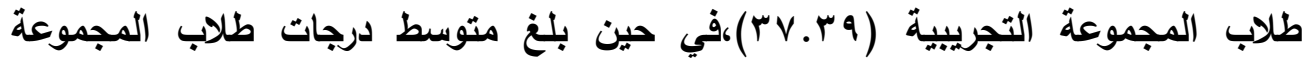

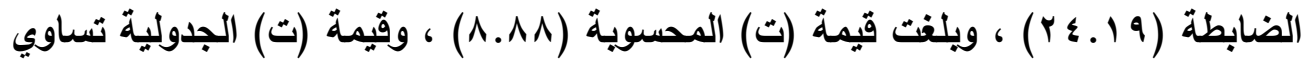

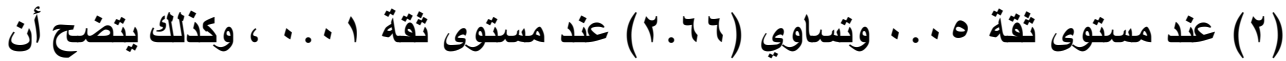

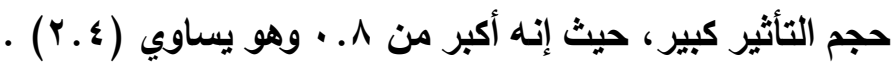
ومما سبق يتضح أن قيمة "ت" المحسوية أكبر بكثير من قيمة "ت" الجدولية عند مستوى ه ... ، ومستوى 1 .. . . ، مما يدل على وجود فرق دال إحصائيا لصالح طلاب المجموعة التجريبية في الاختبار ككل . أهوى ومسن النتـائج السـابقة يتضـح أن هنـاك فـروق ذات دلاعـة إحصـائية لصـالح طـلاب المجموعة التجريبية فى التطبيق البعدى لاختبار التفكير الإيجابي في كل بعد على حده ، وفى الاختبار ككل ؛ مما يؤدى إلى قبول صحة الفرض الثالث للبحث . ع ) اختبار صحة الفرض الرابع للبحث : بالنسبة للفرض الرابع من فروض البحث والذي نص على ما يلي " توجد فروق ذات دلالة إحصائية بين متوسطي درجات طلاب المجموعة التجريبية في التطبيقين القبلى والبعدى لاختبار التفكير الإيجابي لصالح التطبيق البعدى " .

ولاختبار صحة هذا الفرض تم استخدام اختبار "ت" لعينتين مرتبطتين Paired Sample) T-test) بين متوسطات درجات طلاب المجموعة التجريبية في التطبيقين القبلى والبعدى لاختبار التفكير الإيجابي ، كما تم استخدام معادلة كوهين للتأكد من حجم التأثير ، وجدول (1 يوضح هذه النتائج : 
استخدام نموذج مقترح قائم على نظرية الذكاء الناجح

جدول (11) (11)

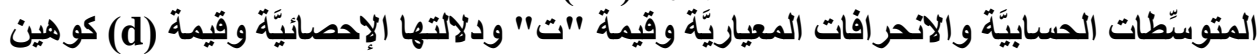

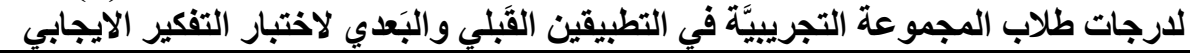

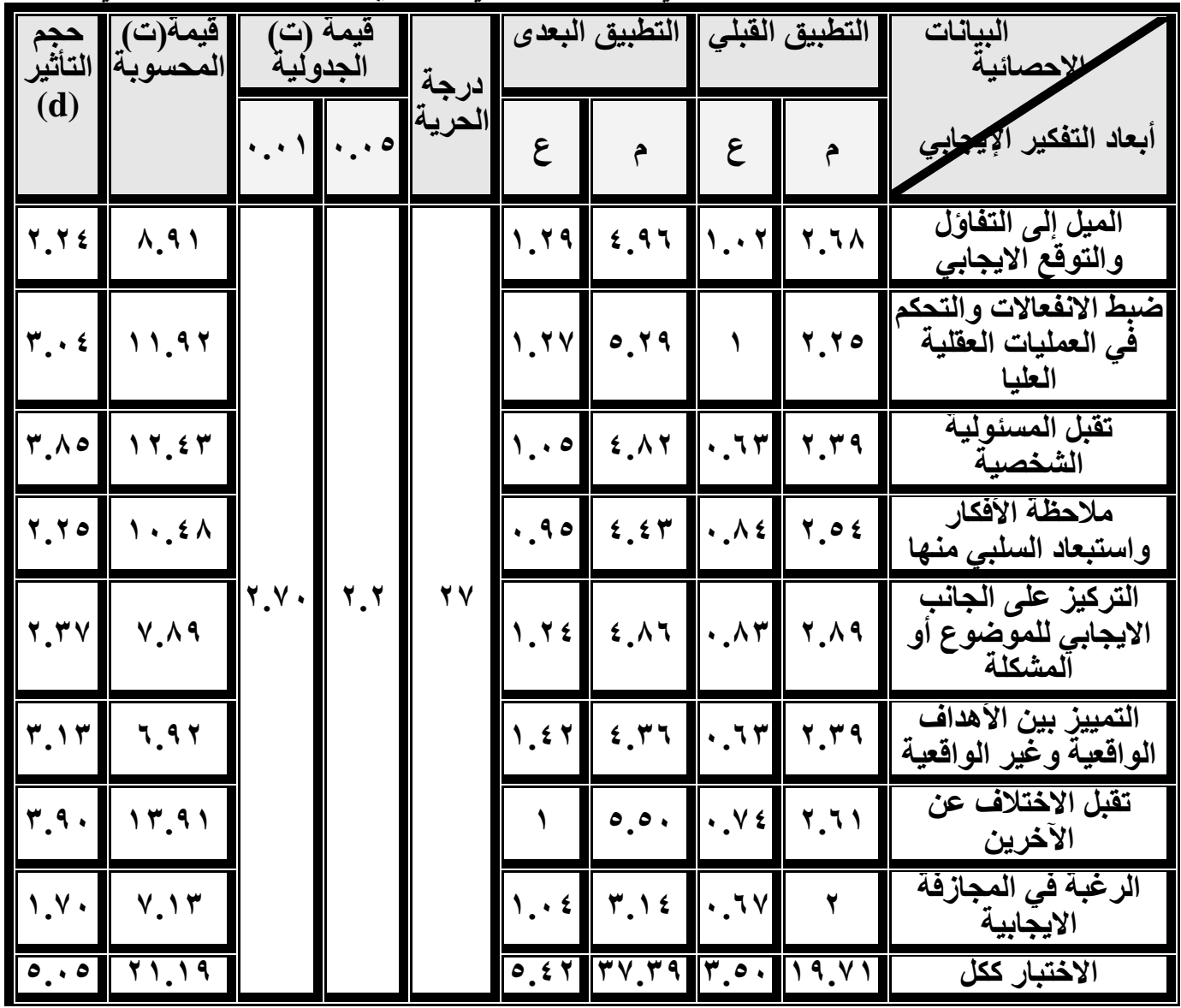

ويتضح من جدول (11) : وجود فروق ذات دلالة إحصائَّةّ-عند مستوى عند مستوى ه ... ، ومستوى 1 .. . . - بين متوسنّطات درجات طلاب المجموعة التجريبيَّة في التطبيقين القَبلي والبَعدي لاختبار التفكير الإيجابي ، فى الاختبار ككل ، وفى كل بعد على حده ، وذلك لصالح التطبيق البعدى . حيث بلغت قيم (ت) للاختبار ككل (19 1. 1. ) ، ويالنسبة للأبعاد الفرعية للتفكير الإيجابي وهى : (الميل إلى التفاؤل والتوقع الايجابي ، ضبط الانفعالات والتحكم في العمليات العقلية العليا ، تقبل المسئولية الثخصية ، ملاحظة الأفكار واستبعاد السلبي منها ، التركيز على الجانب الايجابي للموضوع أو المشكلة، التمييز بين الأهداف الواقعية وغير الواقعية ، تقبل الاختلاف عن الآخرين ، الرغبة في المجازفة الايجابية) جاعت

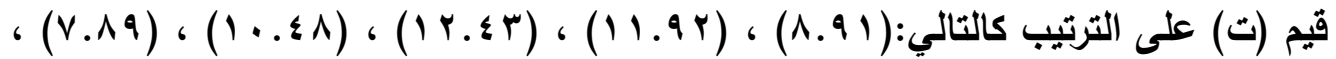




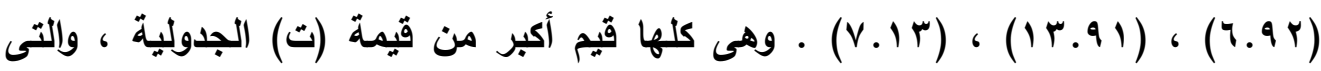

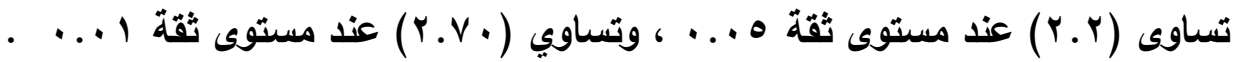
كما يتَّح من جدول (11): أن قيم (d) كوهين في اختبار التفكير الإيجابي ككل (ه..0)، ويالنسبة للأبعاد الفرعية للتفكير الإيجابي وهى : (الميل إلى التفاؤل والتوقع التهابئ

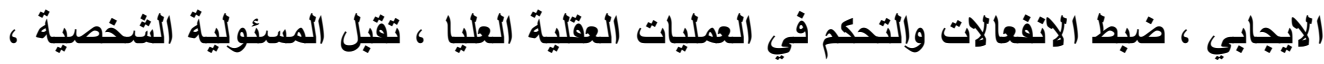

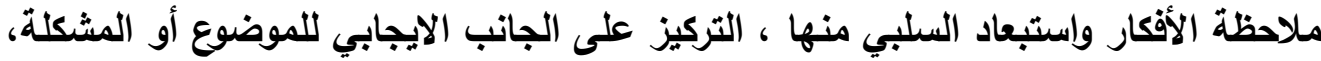

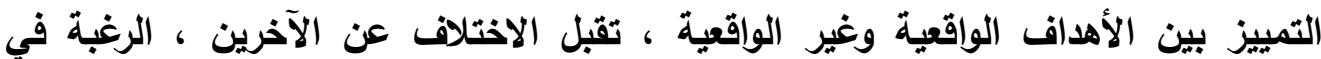

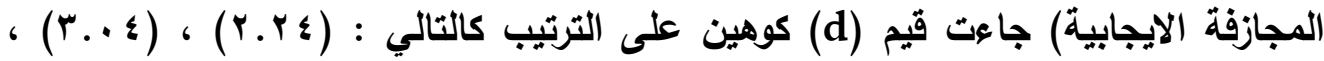

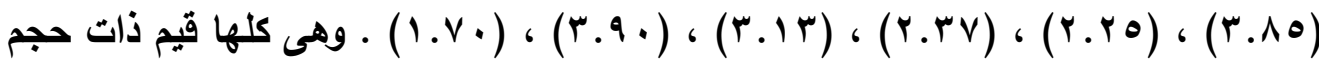
تأثير كبير، حيث أنها أكبر من ^.. ومن النتائج السابقة يتضح أن هناك فروق ذات دلالة إحصائية بين متوسطي درجات طلاب المجموعة التجريبية في التطبيقين القبلى والبعدى لاختبار التفكير الإيجابي لصالح التطبيق البعدى ، وذلك فى الاختبار ككل ، وفى كل بعد على حده ؛ مما يؤدى إلى قبول

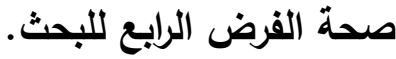

\section{0 ) اختبار صحة الفرض الخامس للبحث :}

بالنسبة للفرض الخامس من فروض البحث والذي نص على ما يلي: " توجد فروق ذات دلالة إحصائية بين متوسطي درجات طلاب المجموعتين التجريبية والضابطة في التطبيق البعدي لمقياس الاتجاهات العلمية لصالح المجموعة التجريبية" .

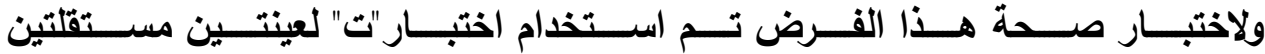
(Independent Sample T-test)؛ لحساب المتوسيّطات الحسابيَّة، والانحرافات المعياريَّة، وقيمة (ت) لدلالة الفروق بين متوسيّات درجات طلاب المجموعتين التجريبيَّة والضابطة في التطبيق البَعدي لمقياس الاتجاهات العلمية ، وجدول (r آ ) يوضِّح هذه النتائج: 


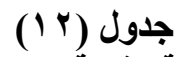

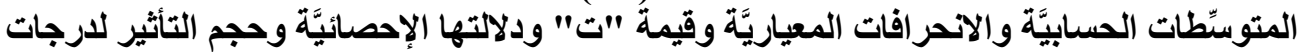

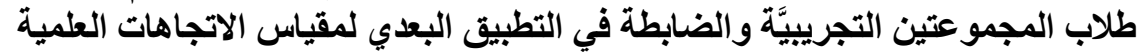

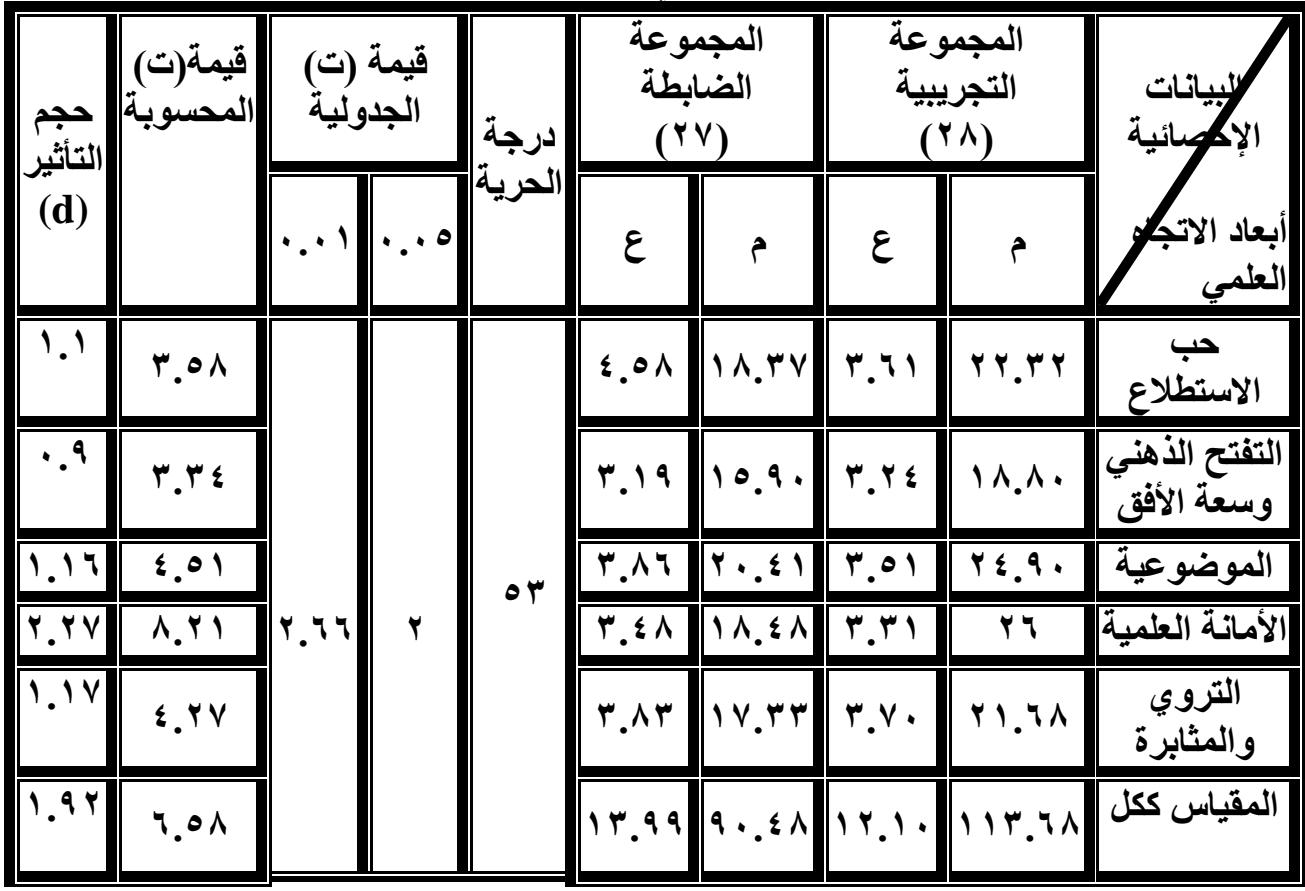

ويتضح من جدول (r I ) ما يلي :

• ارتفاع متوسط درجات طلاب المجموعة التجريبية عن متوسط درجات طلاب المجموعة الضابطة فى التطبيق البعدي لبعد الاتجاه العلمي الخاص بـ(حب الاستطلاع). حيث بلغ متوسط درجات طلاب المجموعة التجريبية (Y.r.r.r)، في حين بلغ متوسط درجات طلاب

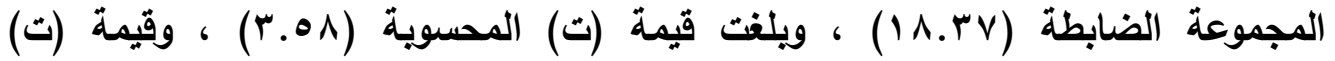

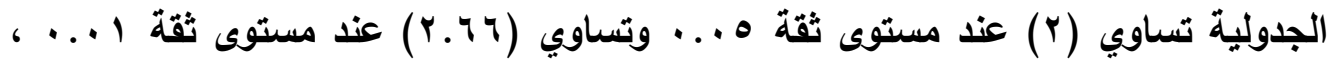

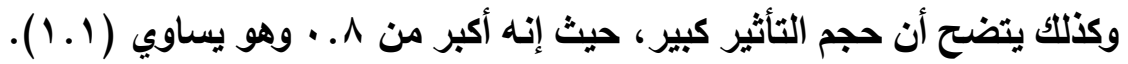
ومما سبق يتضح أن قيمة "ت" المحسوية أكبر بكثير من قيمـة "ت" الجدولية عند مستوى مئ

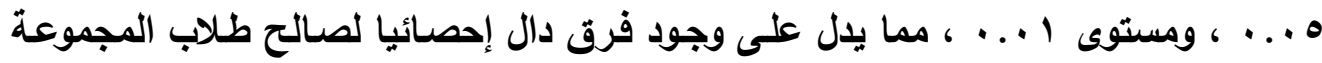
التجريبية في هذا البعد . • ارتفاع متوسط درجات طلاب المجموعة التجريبية عن متوسط درجات طلاب المجموعة الضابطة فى التطبيق البعدي لبعد الاتجاه العلمي الخاص بـ (التفتح الذهني وسعة الأفق).

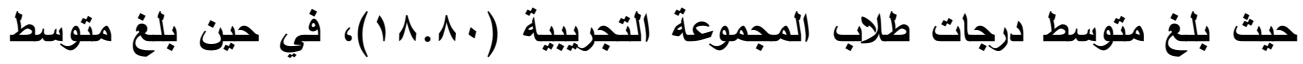




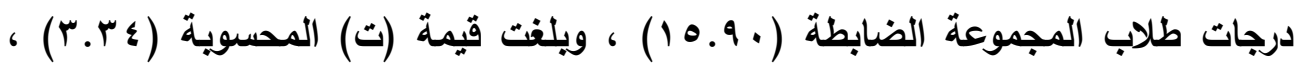

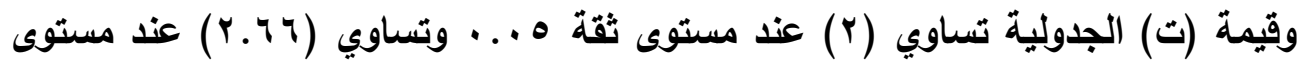
ثقة ا ... ، وكذلك يتضح أن حجم التأثير كبير، حيث إنه أكبر من ^. . . وهو يساوي

وممـا سـبق يتضـح أن قيمـة "ت" المحسـوية أكبـر بكثير مسن قيمـة "ت" الجدوليـة عنـــ مستوى ه .. . ، ومستوى ا .. . ، مما يدل على وجود فرق دال إحصائيا لصالح طلاب المجموعة التجريبية في هذا البعد . ماتهوي • ارتفاع متوسط درجات طلاب المجموعة التجريبية عن متوسط درجات طلاب المجموعة الضابطة فى التطبيق البعدي لبعد الاتجاه العلمي الخاص بـ (الموضوعية). حيث بلغ متوسط درجات طلاب المجموعة التجريبية ( • 9. ؟ ؟)، في حين بلغ متوسط درجات طلاب

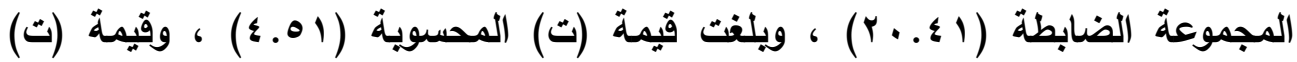

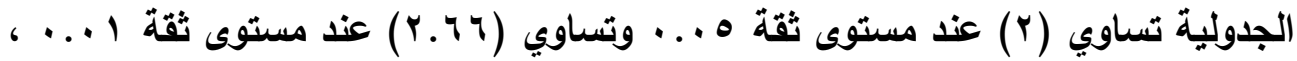
وكذلك يتضح أن حجم التأثير كبير، حيث إنه أكبر من ^. . وهو يساوي (1 1 . 1).

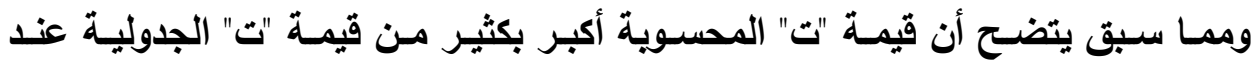
مستوى ه .. . ، ومستوى ا .. . ، مما يدل على وجود فرق دال إحصائيا لصالح طلاب

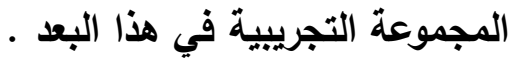
• ارتفاع متوسط درجات طلاب المجموعة التجريبية عن متوسط درجات طلاب المجموعة الضابطة في التطبيق البعدي لبعد الاتجاه العلمي الخاص بـ (الأمانة العلمية). حيث بلغ متوسط درجات طلاب المجموعة التجريبية (؟ ب)، في حين بلغ متوسط درجات طلاب

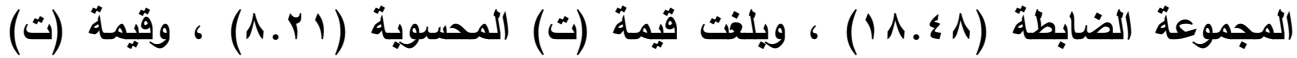

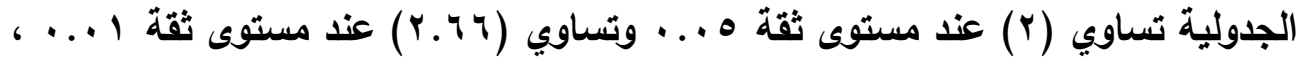

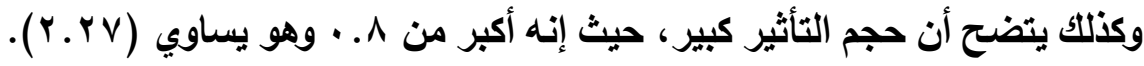
وممـا سـبق يتضـح أن قيمـة "ت" المحسـوية أكبر بكثير مسن قيمـة "ت" الجدوليـة عنـــ مستوى ه .. . ، ومستوى 1 . . . ، مما يدل على وجود فرق دال إحصائيا لصالح طلاب المجموعة التجريبية في هذا البعد . 
• ارتفاع متوسط درجات طلاب المجموعة التجريبية عن متوسط درجات طلاب المجموعة الضابطة فى التطبيق البعدي لبعد الاتجاه العلمي الخاص بـ (التروى والمثابرة). حيث بلغ

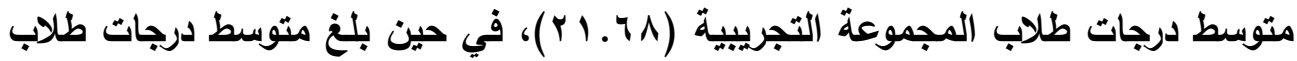

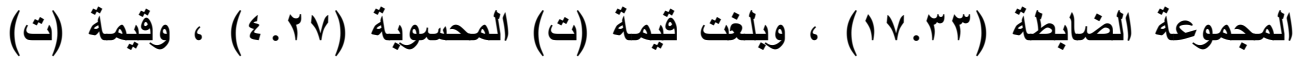

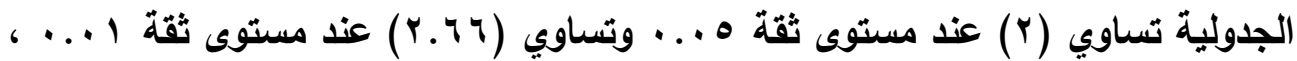

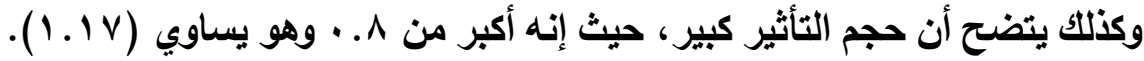

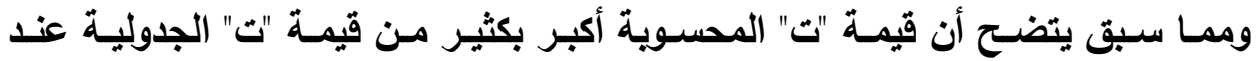
مستوى ه ... ، ومستوى ا .. . ، مما يدل على وجود فرق دال إحصائيا لصالح طلاب المجموعة التجريبية في هذا البعد . • ارتفاع متوسط درجات طلاب المجموعة التجريبية عن متوسط درجات طلاب المجموعة الضابطة فى التطبيق البعدي (لمقياس الاتجاهات العلمية ككل) . حيث بلغ متوسط درجات

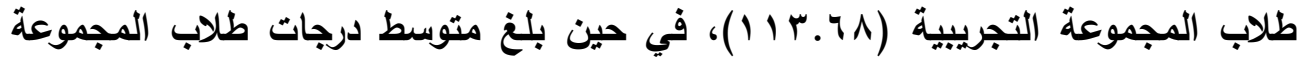

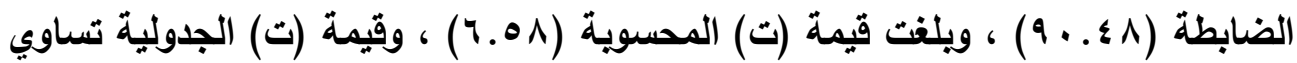

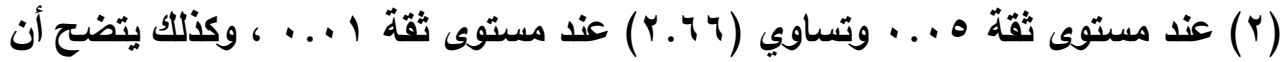

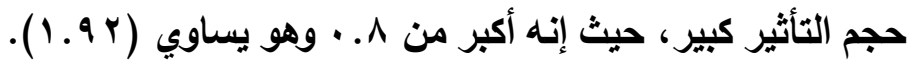
ومما سبق يتضـح أن قيمة "ت" المحسوية أكبر بكثير من قيمـة "ت" الجدولية عند الته مستوى ه ... ، ومستوى ا ... ، مما يال على وجود فرق دال إحصائيا لصالح طلاب المجموعة التجريبية في المقياس ككل .

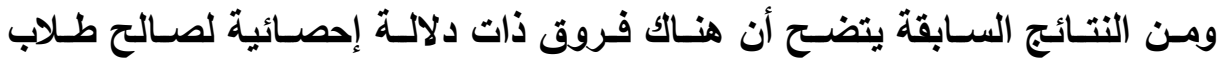
المجموعة التجريبية فى التطبيق البعدى لمقياس الاتجاهات العلمية في كل بعد على حده ، وفى المقياس ككل ؛ مما يؤدى إلى قبول صحة الفرض الخامس للبحث . 7 ) اختبار صحة الفرض السادس للبحث : بالنسبة للفرض السادس من فروض البحث والذي نص على ما يلي: " توجد فروق ذات دلالة إحصائية بين متوسطي درجات طلاب المجموعة التجريبية في التطبيقين القبلى والبعدى لمقياس الاتجاهات العلمية لصالح التطبيق البعدى " . 
ولاختبار صحة هذا الفرض تم استخدام اختبار"ت" لعينتين مرتبطتين Paired Sample) T-test) بين متوسطات درجات طلاب المجموعة التجريبية في التطبيقين القبلى والبعدى لمقياس الاتجاهات العلمية ، كما تم استخدام معادلة كوهين للتأكد من حجم التأثير، وجدول (r I ) يوضح هذه النتائج :

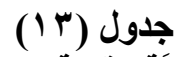

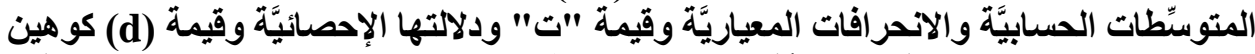

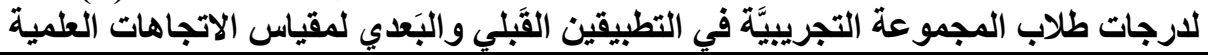

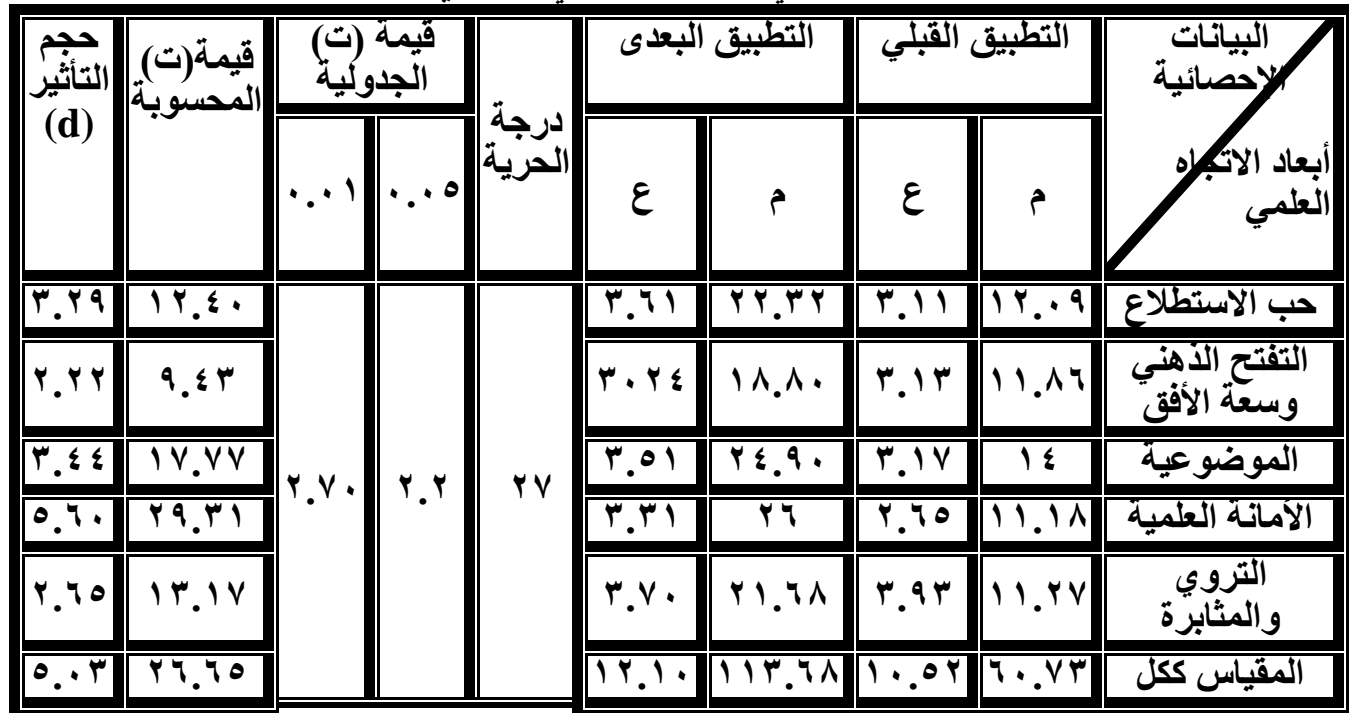

ويتضح من جدول (r I I) : وجود فروق ذات دلالة إحصائَّة-عند مستوى عند مستوى ه .. . ، ومستوى 1 . . . - بين متوسِّطات درجات طلاب المجموعة التجريبيَّة في التطبيقين القَبلي والبَعدي لمقياس الاتجاهات العلمية ، فى المقياس ككل، وفى كل بعد على حده ،

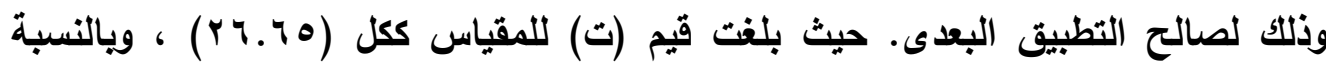
للأبعاد الفرعية للاتجاه العلمي وهى : (حب الاستطلاع ، التقتح الذهني وسعة الأفق ، الموضوعية ، الأمانة العلمية ، التروي والمثابرة) جاعت قيم (ت) على الترتيب كالتالي : التهي

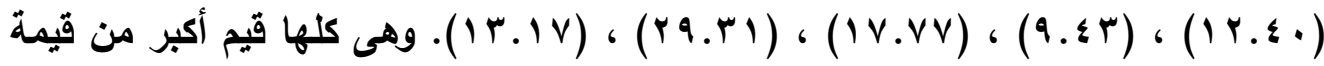

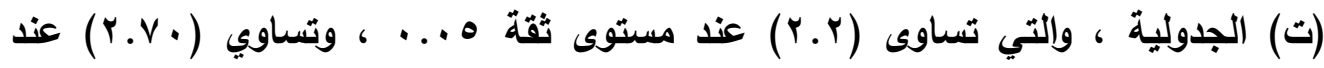


كما يتَّتح من جدول (r) أن قيم (d) كوهين في مقياس الاتجاهات العلمية ككل ( ( . •)، ويالنسبة للأبعاد الفرعية للتفكير الإيجابي وهى : (حب الاستطلاع ، التفتح الذهني وسعة الأفق ، الموضوعية ، الأمانة العلمية ، التروي والمثابرة) جاعت قيم (d) كوهين على الهي

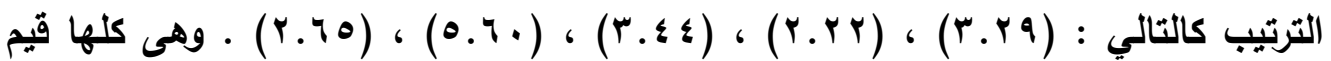

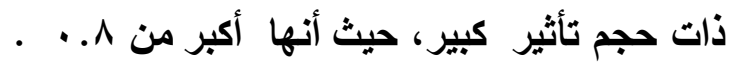
ومن النتائج السابقة يتضح أن هناك فروق ذات دلالة إحصائية بين متوسطي درجات طلاب المجموعة التجريبية في التطبيقين القبلى والبعدى لمقياس الاتجاهات العلمية لصالح التطبيق البعدى ، وذلك في المقياس ككل ، وفى كل بعد على حده ؛ مما يؤدى إلى قبول صحة الفرض السادس للبحث. ومن خلال اختبار صحة جميع فروض البحث يتضح أن استخدام نموذج تدريسي مقترح قائم على نظرية الأكاء الناجح في تدريس وحدة مبادئ التفكير العلمي كان ذات فاعلية في تنمية المفاهيم والتفكير الإيجابي والاتجاهات العلمية لاى طلاب الصف الأول الثانوي . ثالثا : تفسير النتائج في ضوء الأدبيات النظرية والدراسات السابقة ودلالاتها التربوية : يمكن تفسير نتائج البحث في ضوء الأدبيات النظرية والدراسات السابقة ، وبيان ما تتركه تلكك النتائج من دلالة تربوية في النقاط الآتية : ( ) بالنسبة لفاعلية النموذج المقترح- القائم على نظرية الأكاء الناجح- في تنمية المفاهيم لاى طلاب الصف الأول الثانوي من خلال تدريس وحدة مبادئ التفكير العلمي ، فإن هذه النتيجة يمكن تفسيرها في البحث الحالي في ضوء الأسس والمبادئ التي تم الاعتماد عليها في بناء النموذج المقترح ، وما تضمنه هذا النموذج من إجراءات تدريسية دعمت تعلم وتنمية المفاهيم لاى طلاب المجموعة التجريبية ، والتي كان من أهمها ما يلي :

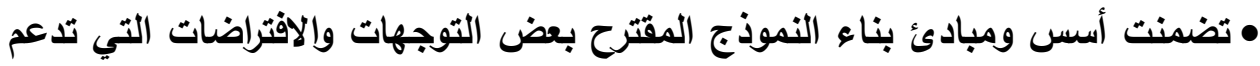
وتعزز من تتمية وتعلم المفاهيم المتضمنة في وحدة مبادئ التفكير العلمي ، والتي من أهمها : إتاحة الفرصة للمتعلم لاستخدام المهارات التحليلية والإبداعية والعملية بشكل

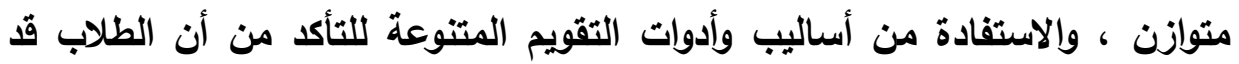
حققوا أهداف التعلم ، والتركيز على إثارة أسئلة مهمة تثير الخبرات السابقة لدى 
المتعلم ؛ بهدف مساعدة الطلاب على تكوين بنية معرفية تتكامل فيها الخبرات القديمة بالجديدة ، واستخدام تقنيات التغذية الراجعة ، من خلال تعزيز نقاط القوة وعلاج جوانب الضعف لاى الطلاب ، وإعداد مهام تقويمية محددة وهادفة وذات معنى ، وأخيرا ريط إجراءات وخطوات النموذج بمستويات المعرفة المختلفة التي يجب على الطالب اكتسابها حول المفاهيم التي تتضمنها وحدة " مبادئ التفكير العلمي " • تضمنت إجراءات التتريس في النموذج المقترح وضع قائمة بالمفاهيم المتضمنة في كل درس ، وذلك في باية كل درس ، وهذا يوجه المعلم إلى أهمية التركيز على تعليم

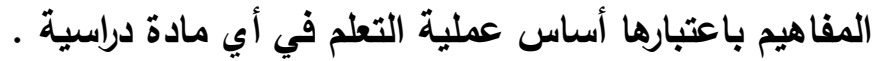
• تضمنت المرحلة الثانية من النموذج المقترح- مرحلة استثارة المعرفة السابقة وتحفيز التفكير- استثارة معلومات الطلاب السابقة عن موضوع الدرس من خلال طرح مجموعة من الأسئلة في شكل أسئلة للعصف الأهني ، وأيضا استخدام الخريطة المعرفية عن موضوع الارس ، وتوجيه الطلاب إلى استخدام عمليات الترميز والتخزين في مراجعة وفحص الخريطة المعرفية لمفاهيم وموضوعات الدرس · وكل هذه الإجراءات تدعم وتعزز من عمليات إتقان المفاهيم وتعلمها لدى الطلاب. حيث أن الخرائط المعرفية هى فى طبيعتها تنظيم هيكلي لمفاهيم الدرس . • تضمنت المرحلة الثالثة من النموذج المقترح- مرحلة تدعيم القدرات الثلاث للأكاء الناجح- إعداد وتصميم الطلاب لمخططات معرفية توضح الأفكار والعناصر الأساسية لموضوع الدرس ، وهذا يمثل أحد جوانب التغذية الراجعة والتقويم المستمر الخاص

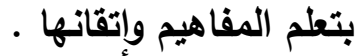
• أتاح النموذج المقترح الفرصة للطلاب للإجابة عن بعض الأسئلة الثفهية في مرحلة التقويم والموازنة يساعد المعلم في الكثف عن أي تصورات خاطئة لاى الطلاب عن المفاهيم المتضمنة في الدرس ، ويالتالي يمكنه تصحيح تلك التصورات بشكل فوري، مما يدعم جوانب التعلم اللاحق للمفاهيم في الدروس التالية . • تضمن النموذج المقترح إتاحة الفرصة للطلاب للإجابة عن بعض الأسئلة الخاصة بتدعيم فهم المفاهيم ومهارات التفكير العليا في مرحلة التدعيم والمتابعة. ولا شك أن بهن هذا النوع من الأسئلة ينمى لاى الطلاب عمليات وأبعاد الفهم العميق للمفاهيم 


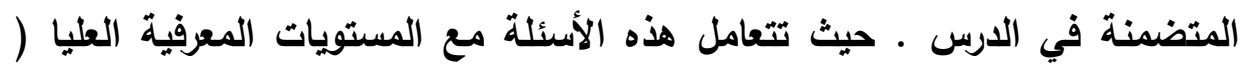

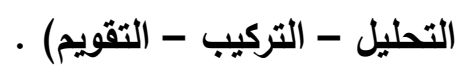

وتتفق هذه النتيجة مع بعض الدراسات الأخرى ، التي أوضحت فاعلية نظرية الذكاء

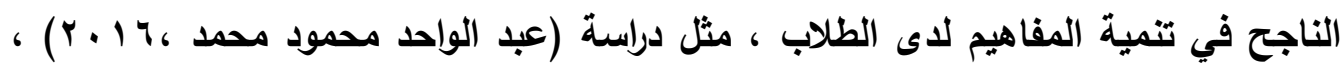

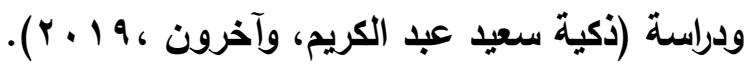

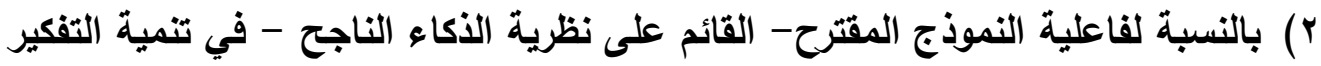

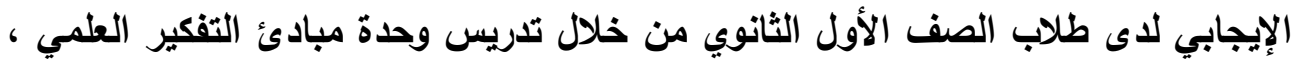
فإن هذه النتيجة يمكن تفسيرها في البحث الحالي في ضوء الأسس والمبادئ التي تم الاعتماد عليها في بناء النموذج المقترح ، وما تضمنه هذا النموذج من إجراءات تدريسية فئية

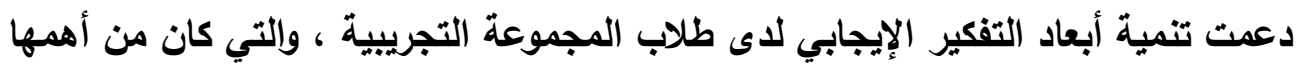
ما يلي : مان • تضمنت أسس ومبادئ بناء النموذج المقترح بعض التوجهات والافتراضات التي تدعم وتعزز من تنمية أبعاد التفكير الإيجابي لاى الطلاب ، والتي من أهمها : تدريب الطلاب التهاب

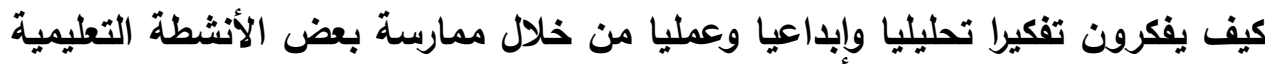

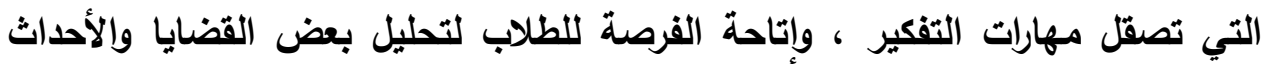
الجارية ،من خلال التركيز على الجانب الايجابي للقضية أو الحدث ، واستبعاد ما يطرح

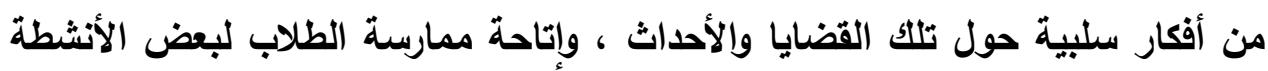

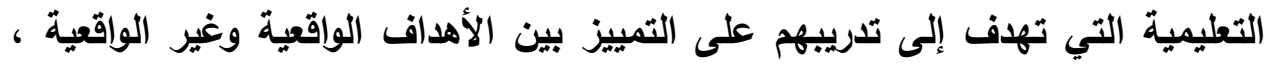
وتقبل المسئولية الثخصية ، وتتمية روح المجازفة الايجابية ، وتقبل الاختلاف عن الإنه الآخرين ، والتحكم في العمليات العقلية العليا . • تضمنت المرحلة الثالثة من النموذج المقترح- مرحلة تدعيم القدرات الثلاث للأكاء لئاء

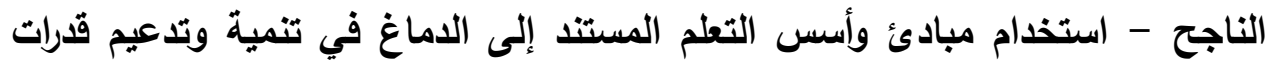

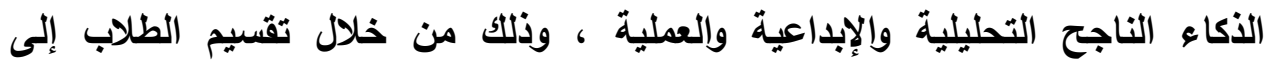

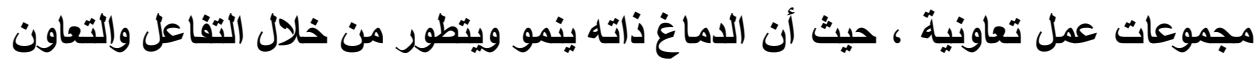

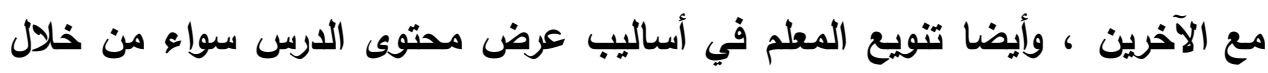
أورلق العمل أو الاستعانة بالكتاب المدرسي على جهاز التابلت ؛ وذلك لإحداث توازن 
بين القدرات التحليلية (الجانب الأيسر للاماغ) والقدرات الإبداعية (الجانب الأيمن للاماغ) ، بالإضافة إلى توجيه الطلاب لذكر بعض الأمثلة والمواقف التي يمكن من

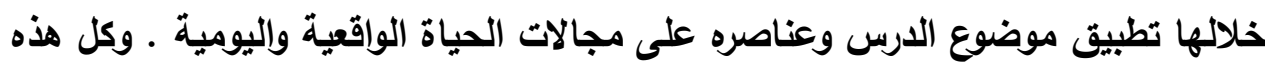
الإجراءات تدعم من قدرات التفكير الايجابي لدى الطلاب. وهذا ما أكدته بعض الدراسات السابقة التي أظهرت فاعلية إجراءات التدريس القائمة نظرية التعلم المستتد إلى الاماغ الهاب في تنمية الاتجاهات الايجابية لاى الطلاب ، مثل دراسة (عبدالله إبراهيم يوسف

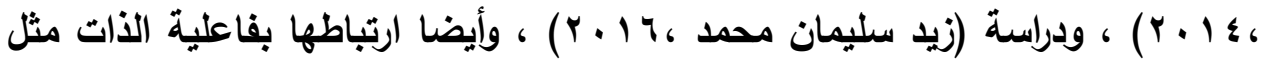

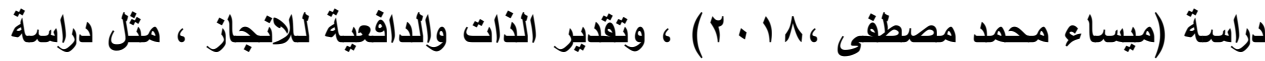

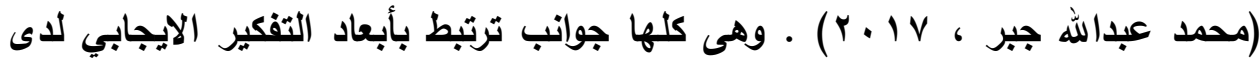
الطلاب .

• تضمن النموذج المقترح استخدام بعض استراتيجيات ومداخل التدريس التي تتوافق مع مبادئ وتوجهات نظرية الذكاء الناجح. حيث تضمن النموذج المقترح الإجابة عن أسئلة للعصف الاهني المطروحة في مرحلة تحفيز التفكير واستثارة المعرفة السابقة ، كذلك تضمن المشاركة بفاعلية في مجموعات التعليم التعاوني في مرحلة تدعيم القدرات الثلاث للأكاء الناجح • وأخيرا تضمن استخدام الأمثلة الشارحة من خلال توجيه الطلاب لذكر مئر بعض الأمثلة والمواقف التي يمكن من خلالها تطيق موضوع الدرس وعناصره على مجالات الحياة الواقعية واليومية ، وذلك لتمية وتدعيم القدرات العملية لديهم ـ ولا شك أن كل هذه الاستراتيجيات والمداخل التدريسية تتضمن في طبيعتها وفلسفتها التريسية بعض الإجراءات التي تعزز وتدعم قدرات التفكير الإيجابي لاى الطلاب . • تنفيذ الطلاب لأنشطة التعلم الفردية في المرحلة الثالثة من النموذج المقترح - وهى الإيى مرحلة تدعيم القدرات الثلاث للأكاء الناجح - فبعض هذه الأنثطة تضمن تحليل الطالب للعديد من المقالات والنصوص، ومارس الطالب من خلال عمليات التحليل والتقويم الخاص بهذه المقالات والنصوص العديد من مهارات وأبعاد التفكر الإيجابي . وتتفق هذه النتيجة مع بعض الدراسات الأخرى ، التي أكلت على فاعلية نظرية الأكاء الناجح في تنمية جوانب التعلم الخاصة بأبعاد التفكير الإيجابي، مثل دراسة

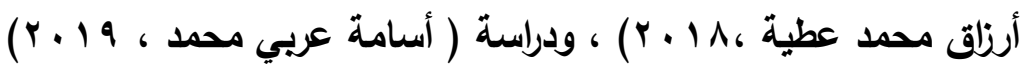


r) بالنسبة لفاعلية النموذج المقترح القائم على نظرية الأكاء الناجح في تنمية الاتجاهات العلمية لاى طلاب الصف الأول الثانوي من خلال تدريس وحدة مبادئ التفكير العلمي ، فإن هذه النتيجة يمكن تفسيرها في البحث الحالي في ضوء الأسس والمبادئ التي تم الاعتماد عليها في بناء النموذج المقترح ، وما تضمنه هذا النموذج من إجراءات تدريسية دعمت تنمية أبعاد الاتجاه العلمي لدى طلاب المجموعة التجريبية ، والتي كان من أهمها ما يلي : • تضمنت أسس ومبادئ بناء النموذج المقترح بعض التوجهات والافتراضات التي تدعم وتعزز من تنمية الاتجاهات العلمية لاى الطلاب - من خلال تدريس وحدة مبادئ التفكير العلمي - والتي من أهمها : تضمين النموذج المقترح بعض الإجراءات والمهام التي تضمن تنمية الميول والاتجاهات العلمية لدى الطلاب من خلال موضوعات وحدة " مبادئ التفكير العلمي " ، خاصة وأن هذه الوحدة توفر العديد من المعارف والخبرات التي مئي تضمن ممارسة الطلاب لهذه الاتجاهات ، والتأكيا على مراعاة الفروق الفردية بين الطلاب ، من خلال التنوع في استراتجيات التدريس المستخدمة ، والتتوع في أنشطة ومصادر التعلم ، والتتوع في أساليب التقويم المختلفة ، بالإضافة إلى الريط بين أنشطة تنمية قدرات الطلاب التحليلية والإبداعية والعملية وممارسة الطلاب لمهارات التفكير الايجابي وتنمية استيعابهم للمفاهيم المنطقية والعلمية وتنمية اتجاهاتهم العلمية . • تضمنت المرحلة الأولى من النموذج المقترح - مرحلة التهميد وتنشيط الذاكرة - إثارة انتباه الطلاب من خلال فكرة إبداعيه، ألغاز، صور، مقاطع فيديو ، مواقف تعليمية ذات صلة بموضوع الارس .، ثم توجيه الطلاب لتحديد المعاني المتضمنة فيما تم عرضه من صورة أو لغز أو فكرة .، وأيضا توجيه الطلاب لطرح بعض الأسئلة المتعقة في ضوء ما توصلوا إليه من معاني ـ فكل هذه الإجراءات تدعم لاى الطلاب بعض أبعاد الاتجاه العلمي ، مثل : حب الاستطلاع ، والتقتح الذهني ، والتروي والمثابرة . • تنفيذ الطلاب لأنشطة التعلم الفردية في المرحلة الثالثة من النموذج المقترح - وهى ، وانى مرحلة تدعيم القدرات الثلاث للأكاء الناجح - فبعض هذه الأنشطة تضمن تحليل الطالب للعديد من المقالات والنصوص المتعلقة بالظواهر العلمية ، ومارس الطالب من خلال 
عمليات التحليل والتفسير الأبعاد المختلفة للاتجاه العلمي وهى:حب الاستطلاع ، والتفتح الذهني وسعة الأفق ، والموضوعية ، والأمانة العلمية ، والتروي والمثابرة . • تضمن النموذج المقترح توجيه الطلاب لتقديم بعض الأفكار غير المألوفة عن موضوع الدرس في مرحلة التدعيم والمتابعة . ولا شك أن هذا الإجراء يعزز من بعض أبعاد الاتجاه العلمي لاى الطلاب مثل : حب الاستطلاع ، والتقتح الذهني ، والمثابرة . وتتفق هذه النتيجة مع بعض الدراسات الأخرى ، التي أكلات على فاعلية نظرية الأكاء الناجح في تنمية أبعاد وجواتب الاتجاه العلمي لاى الطلاب ، مثل دراسة : (دعاء محمد

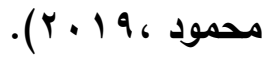
وفى النهاية تثير مجمل النتائج إلى أهمية وفاعلية استخدام النموذج المقترح القائم على نظرية الأكاء الناجح في تدريس وحدة مبادئ التفكير العلمي على تنمية المفاهيم والتفكير الايجابي والاتجاهات العلمية لاى طلاب الصف الأول الثانوي .

\section{رابعا : توصيات البحث :}

في ضوء نتائج البحث يُوصى بما يلي :

1) تقديم نموذج إجرائي يتضمن صياغة موضوعات المواد القلنفية ( الفلسفة - المنطق علم النفس - علم الاجتماع ) في جميع الصفوف الدراسية وفق نظرية الأكاء الناجح ، وذلك لما تتضمنه تلك النظرية من إجراءات تدريسية تدعم وتعزز من نواتج تعلم المواد

r) توجيه انتباه معلمي القلسفة المواد القلسفية في المرحلة الثانوية إلى ضرورة الاهتمام بتنمية وتعليم المفاهيم المتضمنة في المادة الدراسية - وذلك وفق مستوياتها المعرفية

المختلفة - حيث تمثل المفاهيم الهُف الأساسي في تعلم أي مادة دراسية . r) توجيه القائمين على تخطيط وتطوير مناهج القلسفة والمنطق في المرحلة الثانوية إلى ضرورة تضمين المناهج بعض الأنشطة الإثرائية التي تدعم وتعزز من قرات التفكير الإيجابي وأبعاد الاتجاه العلمي لاى الطلاب . \&) وضع دليل لمعلمي الفلسفة والمنطق بالمرحلة الثانوية يتضمن بعض المواقف التعليمية والقضايا القلسفية والعلمية التي يمكن من خلالها تنمية أبعاد التفكير الإيجابي بوائ والاتجاهات العلمية لاى الطلاب . 
•) ضرورة عقد دورات تدريبية لمعلمي الفلسفة والمنطق لتدريبهر على كيفية توظيف

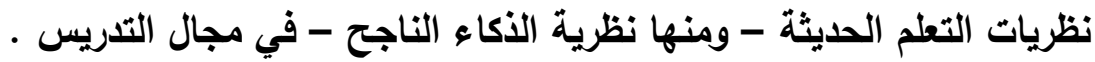
7) وضع دليل لمعلمي الفلسفة والمنطق لمساعدتهم على كيفية إحداث التوازن بين القدرات

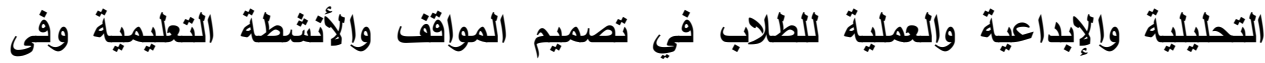
صياغة أسئلة الاختبارات المختلفة . ت توجيه نظر المعلمين والموجهين إلى أهمية استخدام بعض استراتيجيات ومداخل التريس التي تتوافق مع مبادئ وتوجهات نظرية الذكاء الناجح في تدريس الفلسفة والمنطق ، لما لها من فاعلية في تحقيق أهداف ونواتج تعلم المادة .

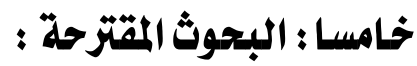
في ضوء نتائج البحث يُقترح القيام بالبحوث الآتية : 1) برنامج مقترح في الفلسفة قائم على نظرية الذكاء الناجح في تنمية المفاهيم والتفكير الإيجابي لاى طلاب المرحلة الثانوية . r) استخدام إستراتيجية مقترحة قائمة على نظرية الذكاء الناجح في تلريس علم الاجتماع الإعائ لتنمية المفاهيم وعادات العقل لاى طلاب المرحلة الثانوية .

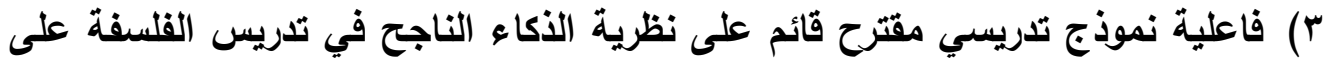
تنمية مهارات التفكير الفلسفي والاتجاه نحو دراسة المادة لاى طلاب المرحلة الثانوية . ؛) فاعلية استخذام نظرية الذكاء الناجح في تدريس وحدة مبادئ التفكير العلمي على تنمية الأكاء التحليلي والعلمي لاى طلاب الصف الأول الثانوي . ه) تطوير منهج الفلسفة في المرحلة الثانوية في ضوء الأبعاد الثلاثية للأكاء .

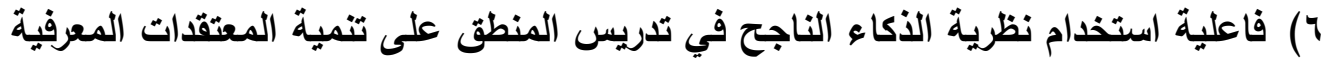
والذكاء الإبداعي لاى طلاب المرحلة الثانوية المتفوقين دراسيا .

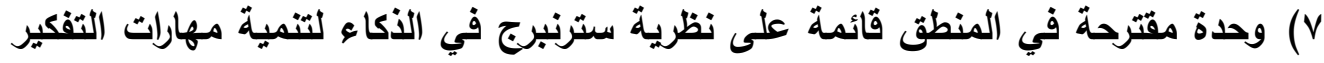
غير الثكلي والكفاءة الذاتية لاى طلاب المرحلة الثانوية .

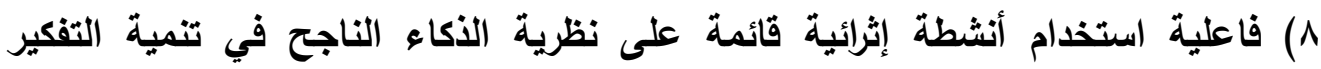

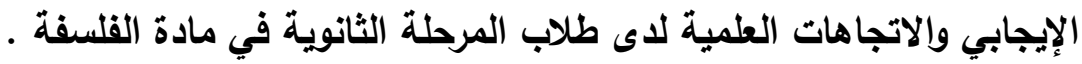




\section{المراجسع}

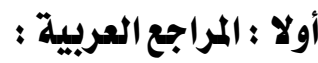

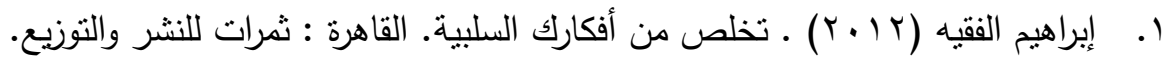

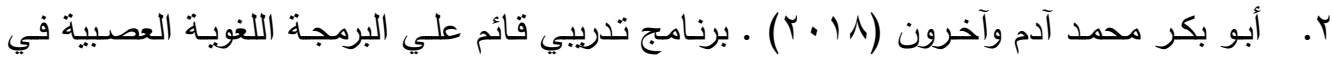

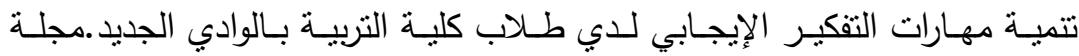

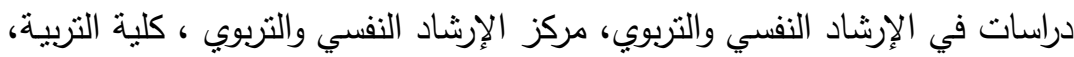

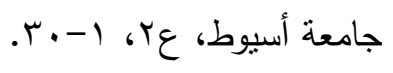

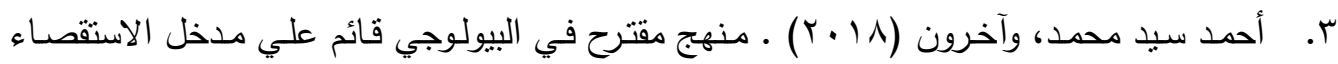

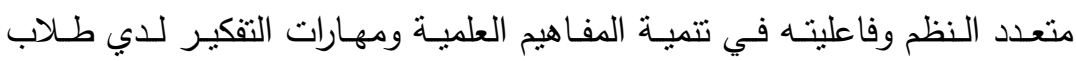

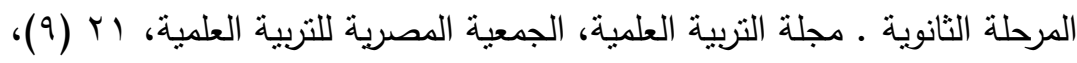

$$
.1 V T-1 \leqslant V
$$

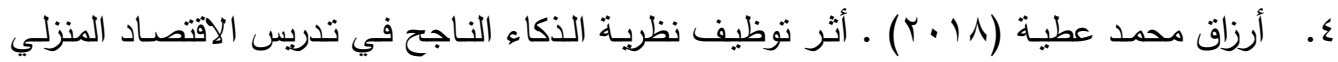

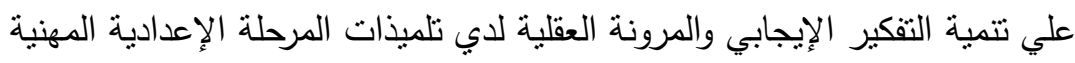

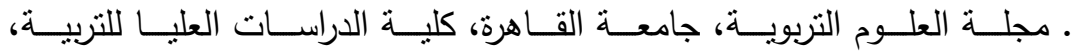

$$
. r) T-1 \leqslant \varepsilon ،(r) r 4
$$

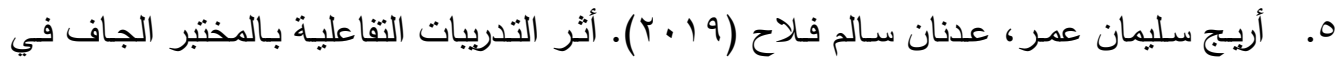

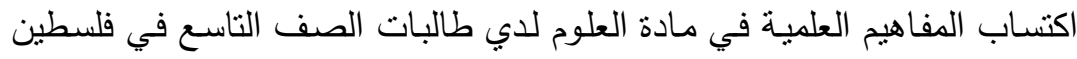

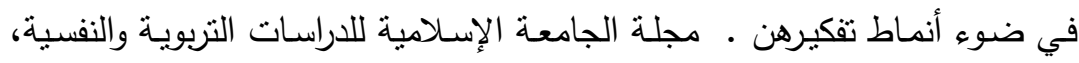

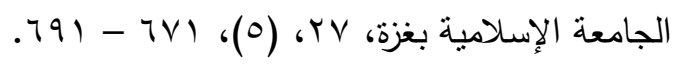

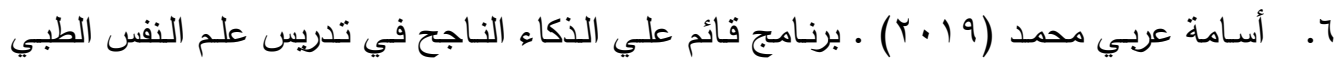

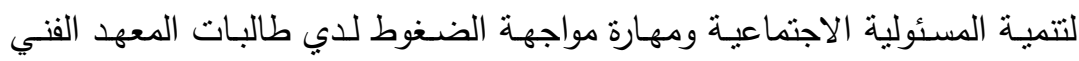

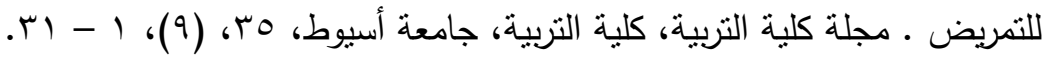

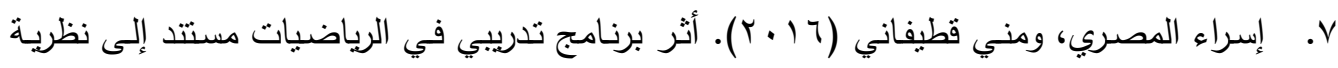

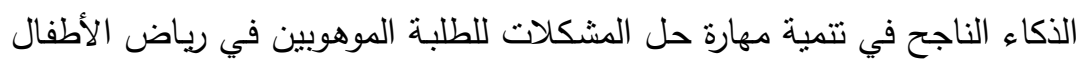

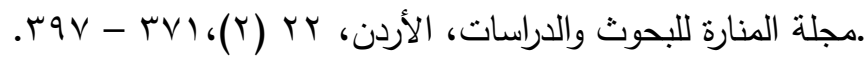

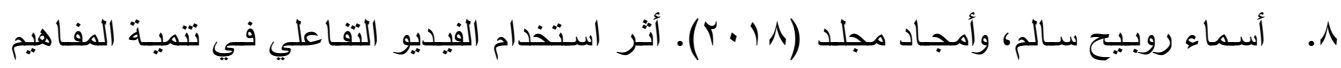

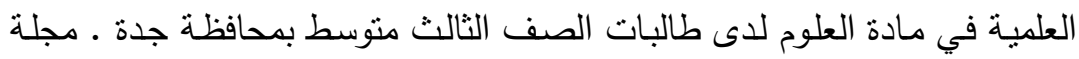
العلوم التزبوية والنفسية، المركز القومي للبحوث، غزة. 
9. إلباس الدومـة آدم (9 ( • ب).المفاهيم العلميـة المضدنة في وحدة الذرة والاتصـالات لكتاب فيزياء الصف الثالث الثانوي ومدى مناسبتها لمتطلبات المرحلة الثانوية بالسودان: دراسـة

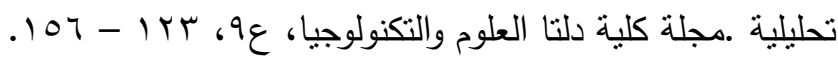

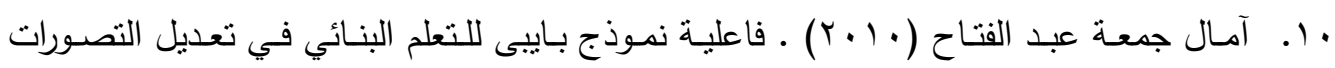
الخاطئة لبعض المفاهيم الفلسفية لاى طلاب المرحلة الثانوية واتجاهاتهم نحو المادة • مجلة دراسـات في المناهج وطرق التدريس ، الجمعيـة المصرية للمنـاهج وطرق

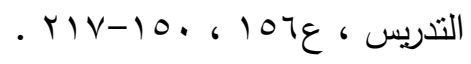

ا ا. أماني محمد عبد الحميد، وآخرون (YV) (Y). فعالية المدخل الجمالي في تدريس البيولوجي لتتمية

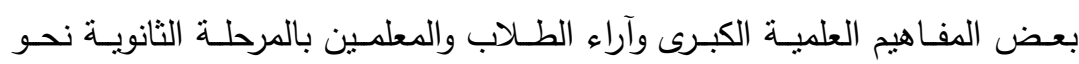
استخدامه. مجلة دراسات فى التعليم الجامعي ، جامعة عين شمس ، كلية التربية ،

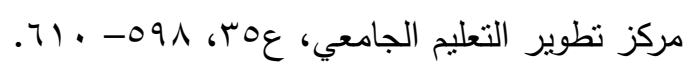

r ا. أميرة جابر هاشم ( ( . . r). أثر برنامج إرشادي باستخدام ثلاثتة أساليب في تتمية الاتجاه العلمي

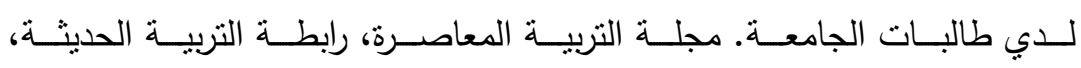

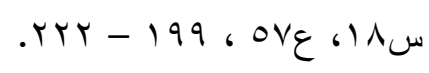

با • إيمان حسنين عصفور (T) ـ (Y). نتشيط المناعة النفسية لتتمية مهارات التفكير الإيجابي وخفض قلق التدربس لدي الطالبات المعلمات شعبة الفلسفة والاجتماع. مجلة دراسات عربية

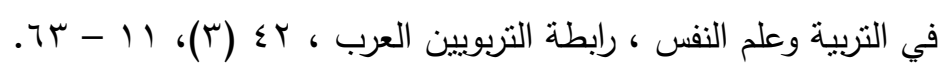

ع ا. باسم صبري محمد (1 1 • r). أثر استخدام نموذج آدي وشـاير Shayer, Adey في الدراسات الاجتماعية علي تتمية مهارات التفكير الإيجابي والاتجاه نحو المشـاركة الوجدانيـة

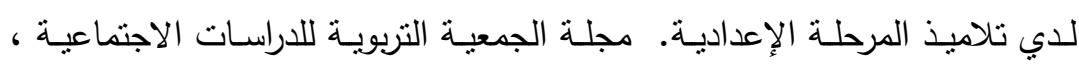

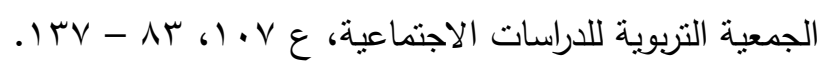

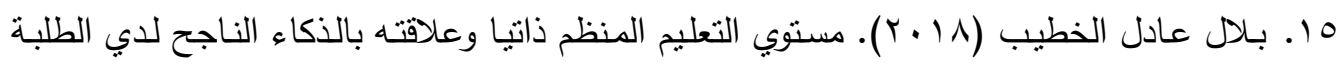

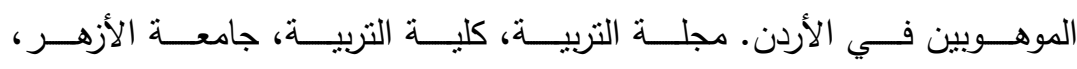

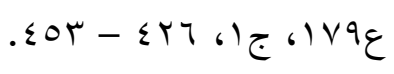

ج ا ـ تهاني العبوس، ورؤوف العاني (r ا • r).أثر إسـتراتيجية الأحداث المتتاقضـة في تتمية المفاهيم والاتجاهات العلمية لدي طالبات المرحلة الأساسية العليا في الأردن. مجلة جامعة

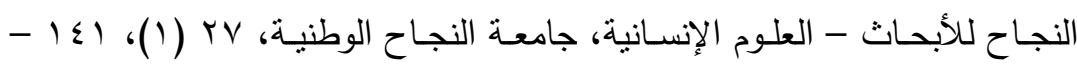

.11 .

V ا. . جابر عبد الحمبد جابر (999 (19) . استراتجيات التدريس والتعلم • القاهرة : دار الفكر العربي • 


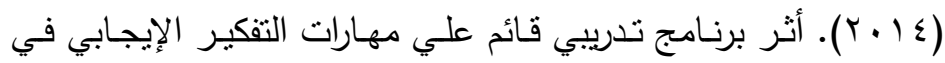
.11

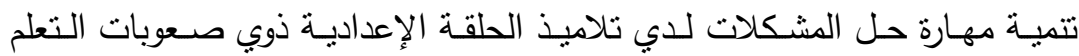

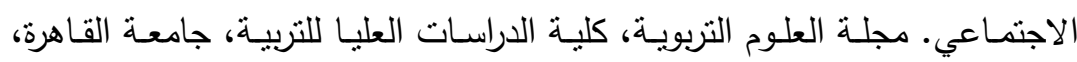

$$
\text { . } 2 \cdot r-r V) ،(r) \text { ( } r \text { r }
$$

9 1. حجازي عبد الحميد أحمد (9 . . ץ). فعالية استخدام المدخل المنظومي في تدريس العلوم في تتمية

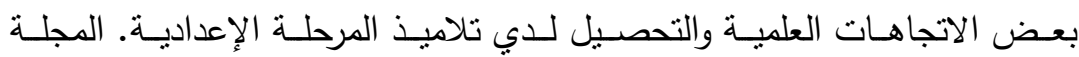

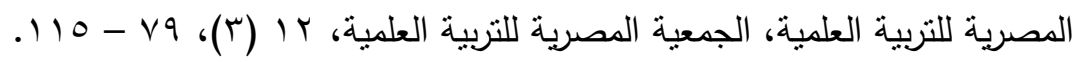

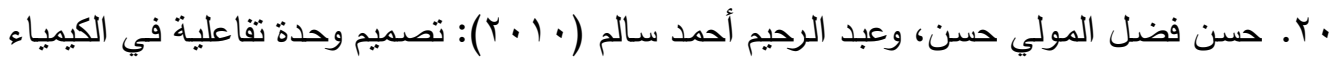

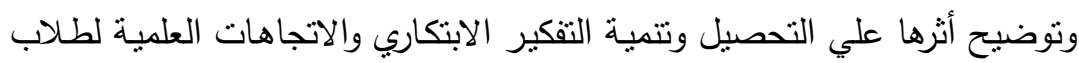

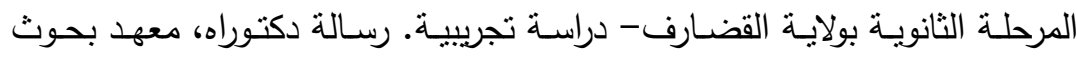
ودراسات العالم الإسلامي، جامعة أم درمان الإسلامية، السودان.

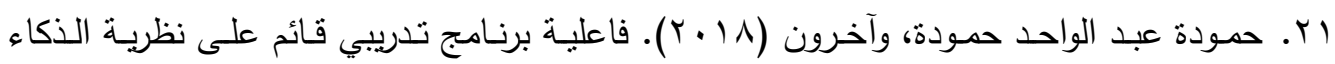

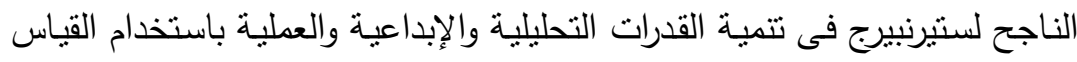
الدينامي. المجلة الدوليـة للآداب والعلوم الإنسـانية والاجتماعية، المؤسسـة العربية

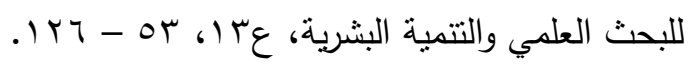

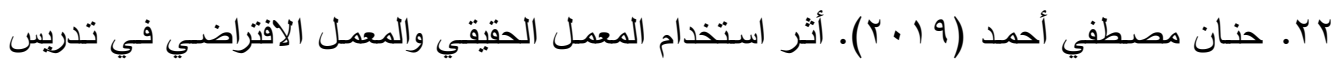

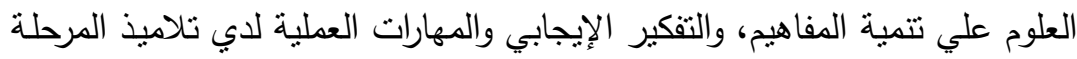

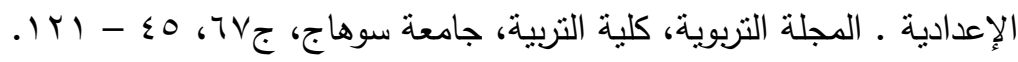

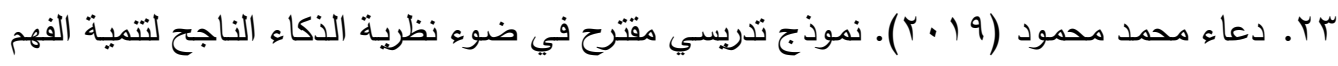

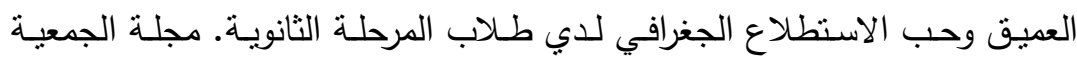

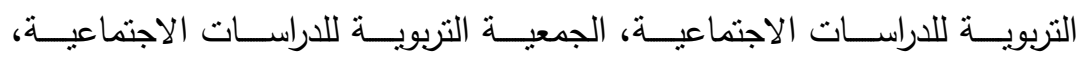

$$
.107-1.6111 \varepsilon
$$

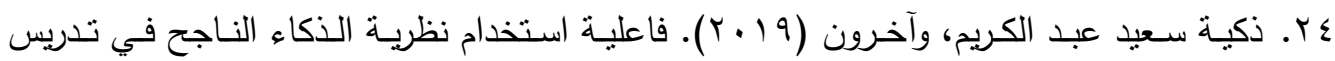
الفلسفة لنتمية مهارات معالجة المعلومات لدي طلاب المرحلة الثانوية. مجلة البحث

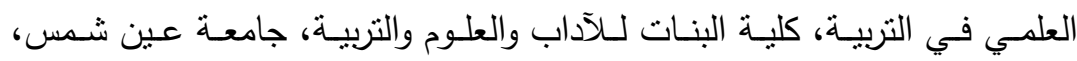

$$
\text { . Q }
$$




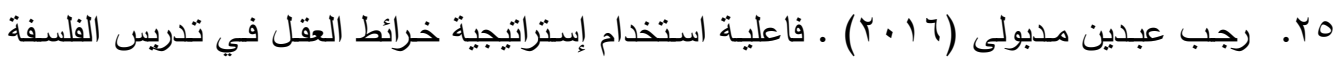
لطـلاب المرحلـة الثانويـة على استيعاب المفاهيم الفلسفية وتتميـة التفكير التأملي ، رسالة ماجستير ، كلية التربية ، جامعة الفيوم • إن

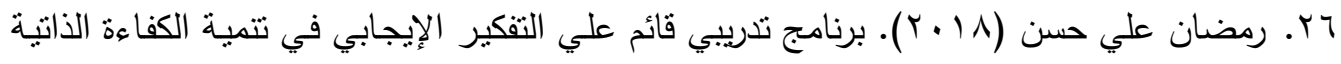
المدركة وأثره في المعتقدات المعرفية لدي طلاب الجامعة. مجلة العلوم التربوية،

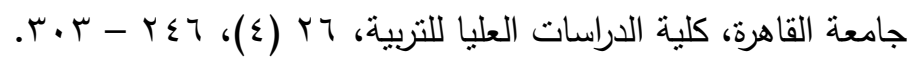

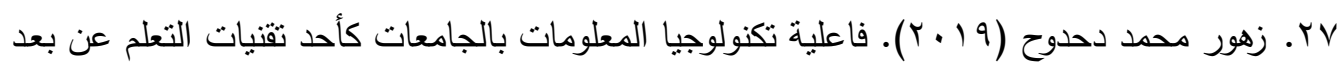
في تتمية الاتجاهات العلمية لدي طالبات الدراسات العليا "تخصص المناهج وطرق تدريس العلوم".المجلـة الدوليـة للعلـوم التربويـة والنفسية، المؤسســة العربيـة للبحـث

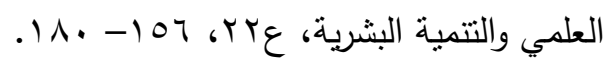

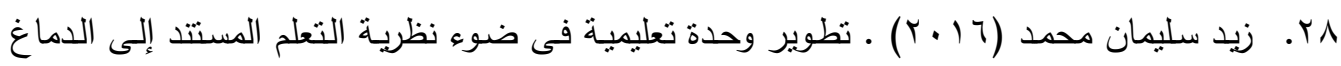
وقياس أثزها فى نتمية مهارات التفكير الناقد لدى طلاب الصف العاشر الأساسي

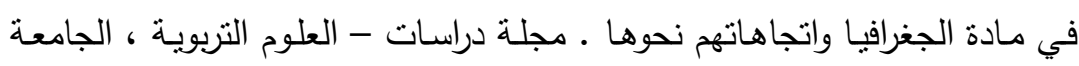

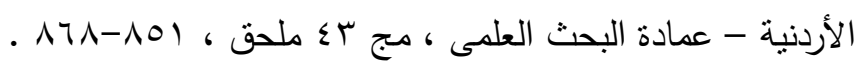

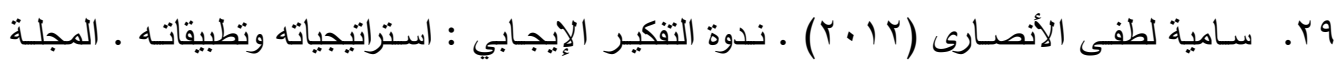

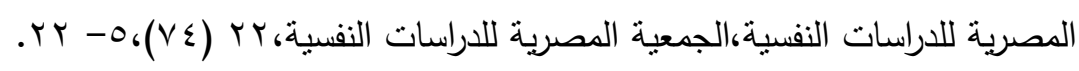

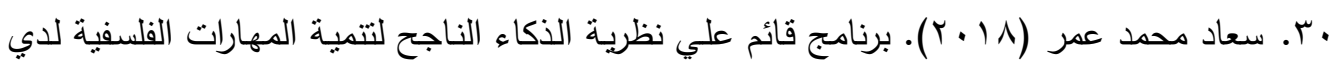
طـلاب المرحلـة الثانويـة. مجلـة دراسـات في المنـاهج وطـرق التـدريس، الجمعيـة المصرية للمناهج وطرق التدريس، ع ابr، 799 - 99.

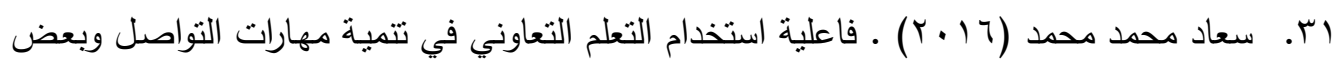
المفاهيم الفلسفية لدى طلاب الصف الأول الثانوي من خلال تدريس مادة الفلسفة،

$$
\text { رسالة ماجستير ، كلية التربية ، جامعة عين شمس . }
$$

r. سعيد محمد صديق (0 1 • r). أثز استخدام مدخل القصة في تدريس العلوم علي التحصيل وتتمية

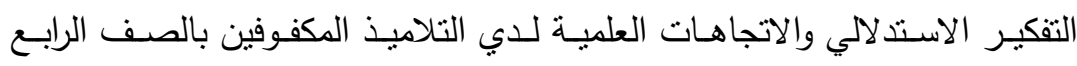

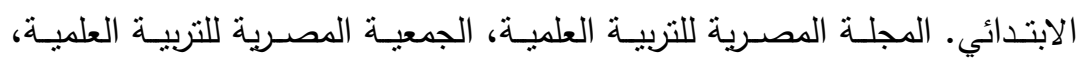

$$
.11 V-\varepsilon V_{6}(r) 11
$$

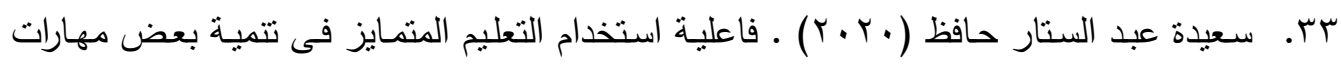
التعلم المنظم ذاتيا والمفاهيم الفلسفية لدى طلاب المرحلة الثانوبية ـ رسالة ماجستير

، كلية التربية بقنا ، جامعة جنوب الوادي . 


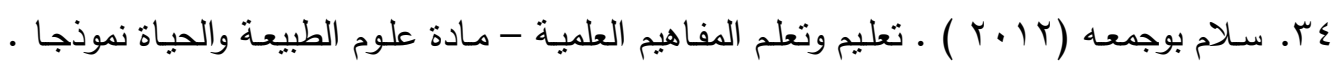

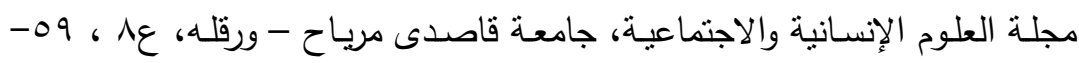

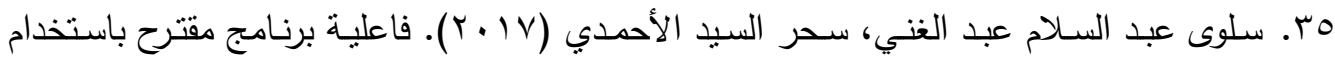

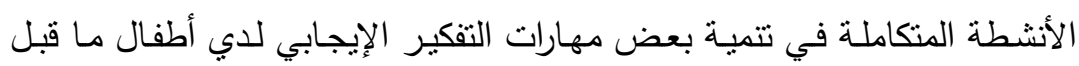

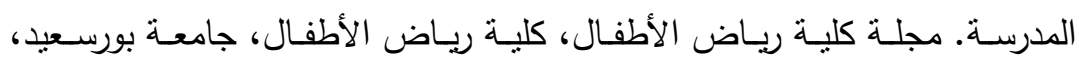

$$
.1 Y)-74 \text { ، } 11 \text { ع }
$$

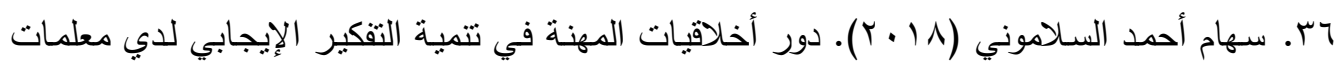

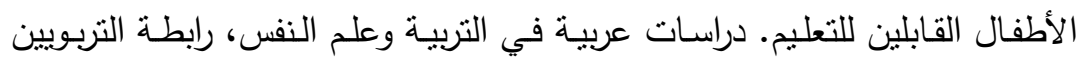

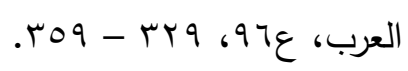

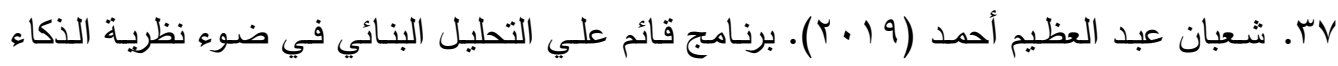

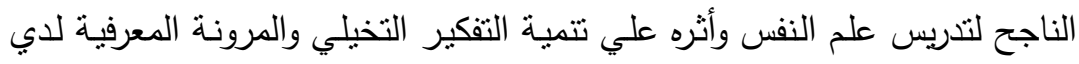

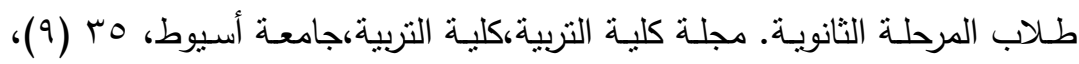

$$
\text { r }
$$

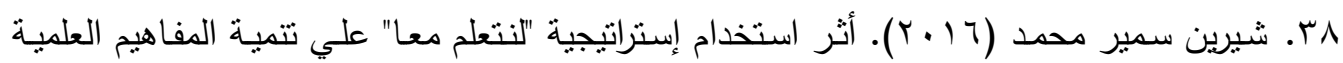

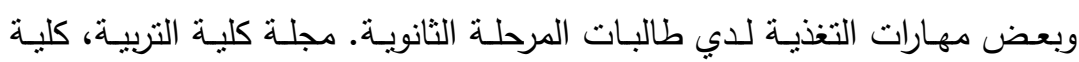

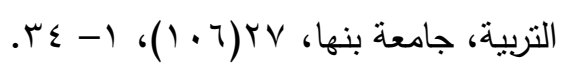

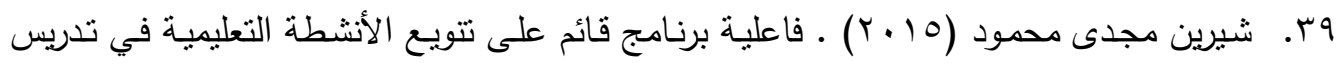

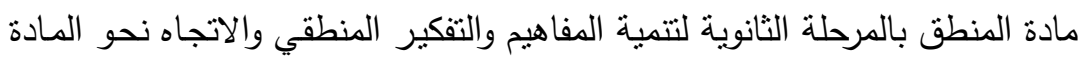

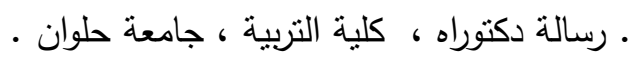

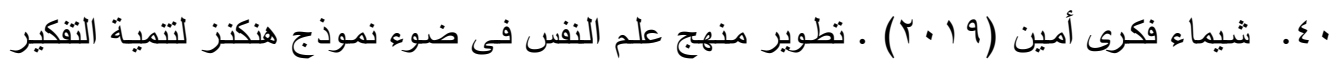

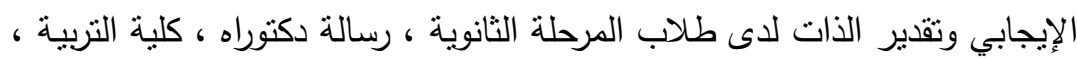

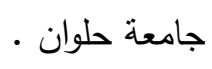

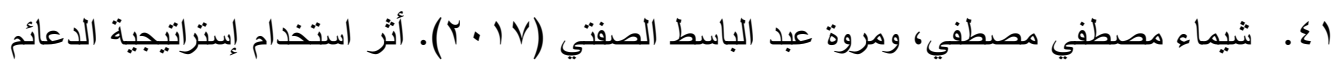
التعليمية في تتمية التفكير الإيجابي والوعي لدي الطالبات للقيام بدورهن كأمهات

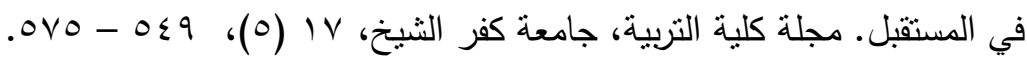

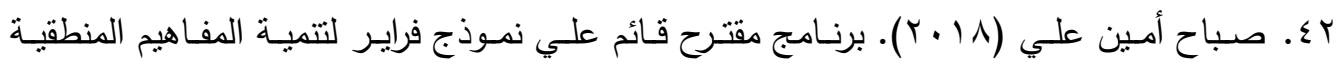

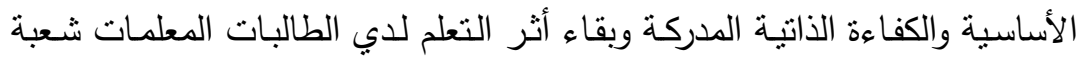


فلسفة واجتماع. مجلة البحث العلمي في التربية، جامعة عين شمس، كلية البنات

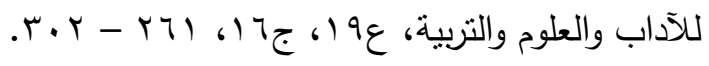

بـ. صفاء محمد علي (ع ( . r). تظوير منهج التاريخ في ضوء نظرية تريز وأثره علي نتمية القدرات التحليليـة والاسـتدلالية والإبداعيـة والتفكيـر الإيجـابي لـدي طـلاب الصـف الأول الثانوي. مجلة الجمعيـة التربوبـة للدراسـات الاجتماعيـة، الجمعيـة التربوبـة للدراسـات

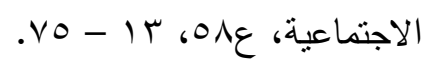

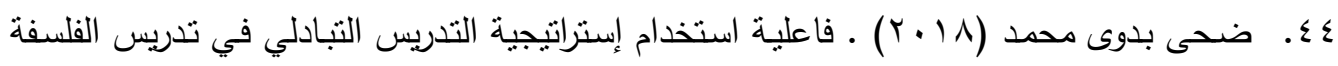
على تتميـة بعض المفـاهيم الفلسفية ومهارات التفكير الناقد لـى طـلاب المرحلـة الثانوبة . رسالة ماجستير ، كلية التربية ، جامعة بنى سويف .

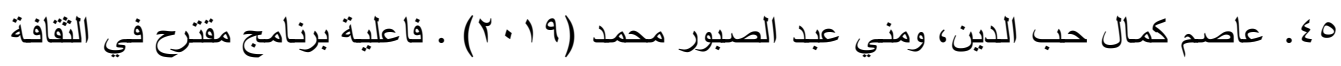

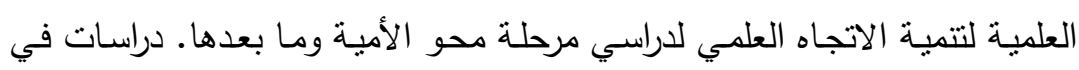

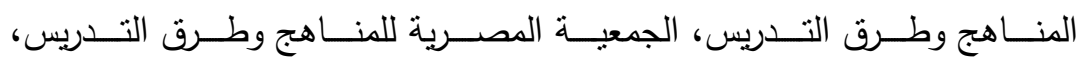

$$
\left..1 \leq 7-1 \leqslant V_{6}\right) T \cdot \varepsilon
$$

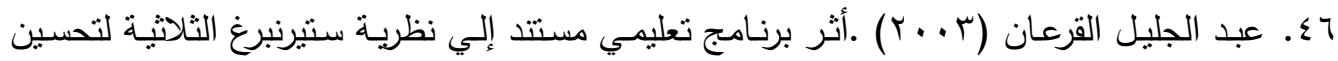
مستوي اتخـاذ القرار لدي طلبـة الصـف الأولي الثانوي (أدبسي / علمي) • رسـالة دكتوراه ، جامعة عمان، العربية للاراسات العليا، عمان الأردن.

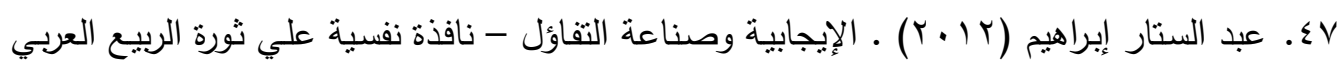
في مصر • القاهرة: المجلس الأعلى للثقافة.

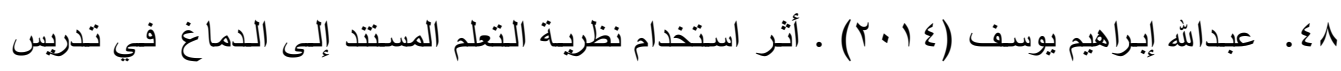
الفلسفة على تتميـة بعض عـادات العقل والاتجـاه نحـو دراسـة المـادة للدى طـلاب المرحلة الثانوية المتفوقين عقليا.مجلة دراسات عربية في التربية وعلم النفس،رابطة

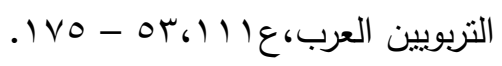

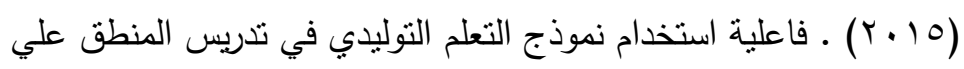
.$\leqslant 9$ تصـيح التصـورات الخاطئة للمفاهيم المنطقيـة وتتميـة الكفاءة الذاتيـة لدي طلاب المرحلـة الثانويـة، مجلـة الجمعيـة التربويـة للاراسـات الاجتماعيـة. الجمعيـة التربويـة

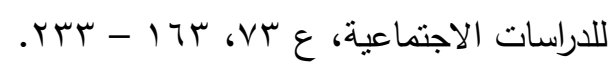

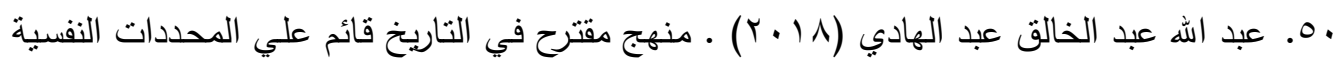
اللازمة لتتمية بعض مهارات التفكير الإيجابي والطموح الدراسي والإنجاز المعرفي 
لاي طلاب المرحلة الثانوية. مجلة الجمعية التربوية للدراسات الاجتماعية، الجمعية

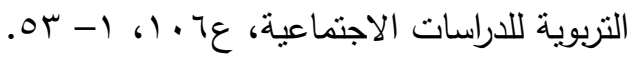

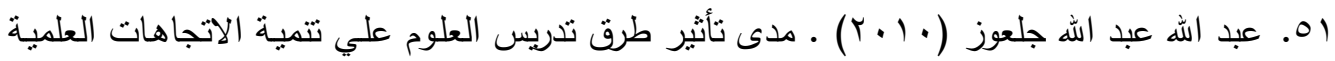

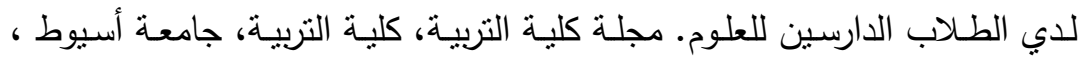

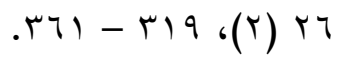

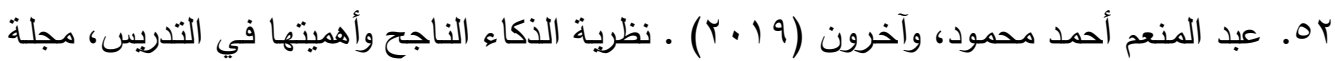

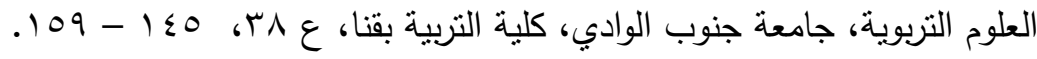

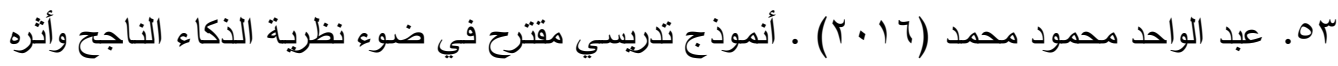
في تحصـيل طـلاب الصـف الرابـع العلمي مـن مـادة الرياضـيات وتتميـة تفكيرهم الإبـداعي، مجلـة تربويـات الرياضـيات، الجمعيـة المصـرية لتربويـات الرياضـيات،

$$
.0 r-7 \text { ( } 9 \text { (9) } 19
$$

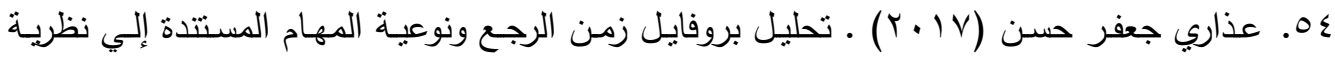
الذكاء الناجح لدي الموهوبين والمتفوقين والمبدعين، رسالة ماجسنير ، كلية الدراسات العليا، جامعة الخليج العربي.

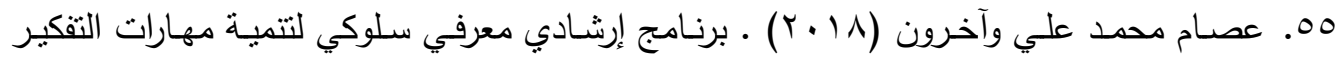
الإيجابي لتحسين جودة الحياة وخفض قلق المستقبل لدي طلبـة المرحلة الثانوبـة. مجلة البحث العلمي في التربية، كلية البنات للآداب والعلوم والتربية، جامعة عين

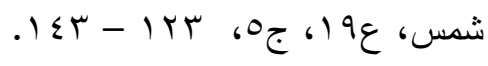

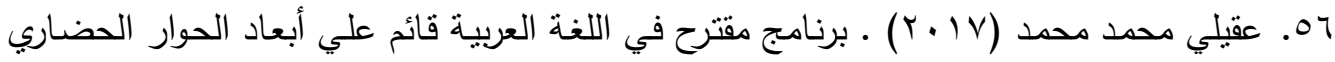
العـالمي لتتميـة مهارات التفكير المستقبلي والتفكير الإيجابي لدي طـلاب المرحلـة

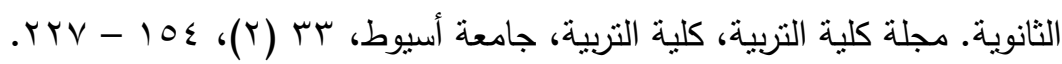

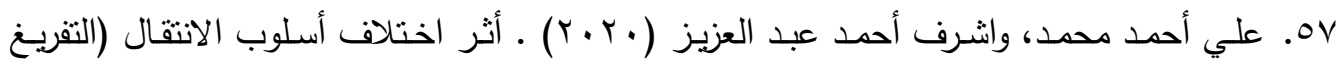
اللوني- قطع (في برامج الحاسوب القائمة علي نتابعات الفيديو الرقمية في تحصبل المفـاهيم العلميـة في مـادة العلـوم لـدي طـلاب المرحلـة المتوسـة. مجلــة القـراءة

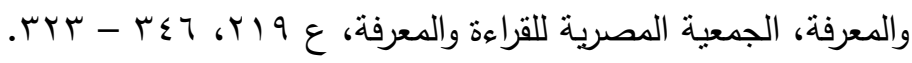

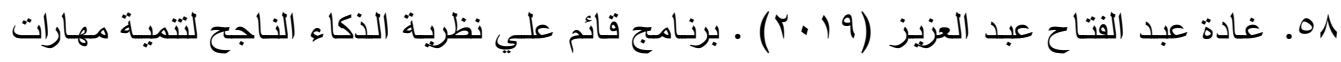
التفكير التاريخي لدي طـلاب المرحلـة الثانويـة. مجلـة الجمعيـة التربويـة للدراسـات

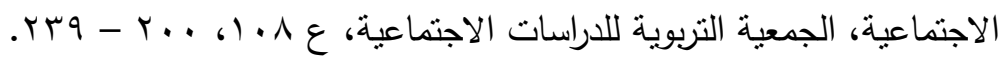




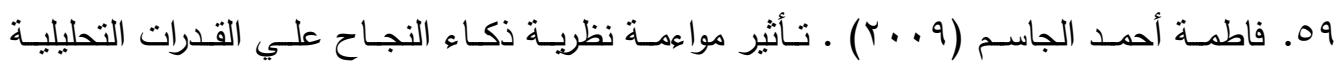
والإبداعية والعملية لمنهج الصف الثالث الابتدائي بمملكة البحرين. رسالة دكتوراه،

$$
\text { جامعة الخليج العربي، البحرين. }
$$

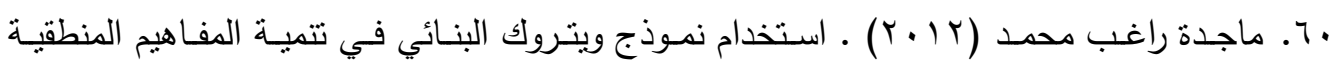
والتفكير المنطقي لدي طلاب المرحلة الثانويـة. مجلة الجمعيـة التربويـة للاراسـات

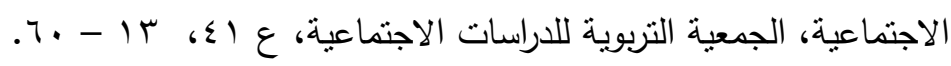

آج. محمد جبر دريب (r (r) ) دور المناهج الدراسية في تتمية التفكير الإيجابي ومهارات الاستذكار لدي طالبات كلية التربية للبنات: بحث ميداني في ضوء بعض المتغيرات. مجلة

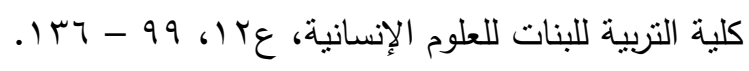

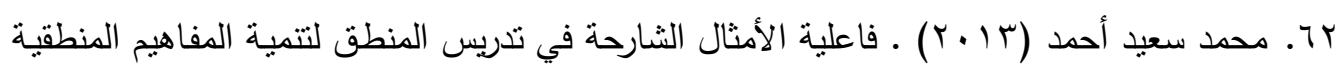
والاتجاه نحو المادة لدي طلاب المرحلة الثانوية. مجلة الجمعية التربوية للاراسات

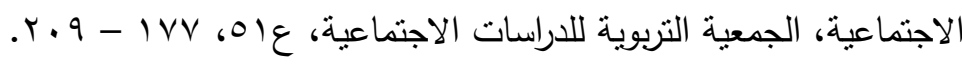

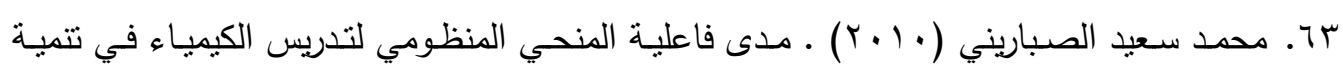
التقكير العلمي والاتجاهات العلميـة لدي طلبة المرحلة الثانويـة في الأردن. المجلة

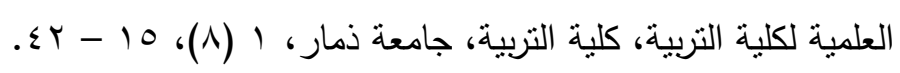

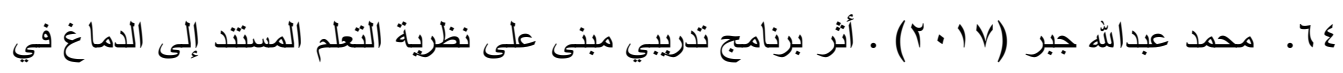

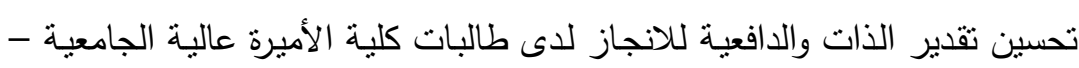

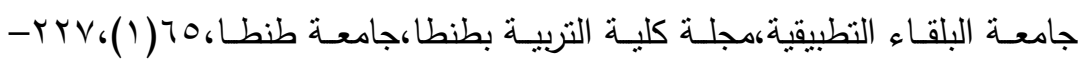

$$
\text { roo }
$$

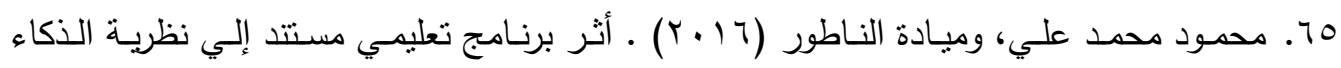
الناجح في تتمية القدرات التحليلية والإبداعية والعملية لدي الطلبة المتفوقين عقليا.

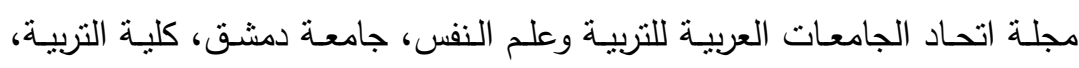

$$
\text { r }
$$

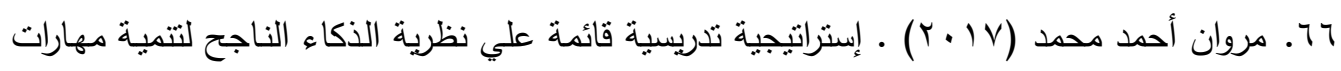
الاستماع لدي دارسي اللغة العربية الناطقين بغيرها من المسلمين. مجلة دراسـات

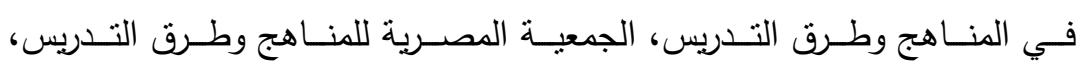

$$
. T V-17, r T / \varepsilon
$$




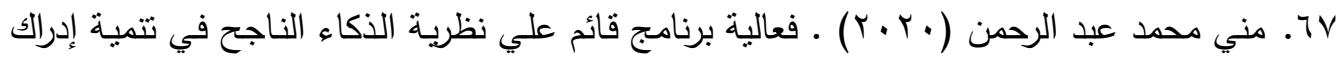

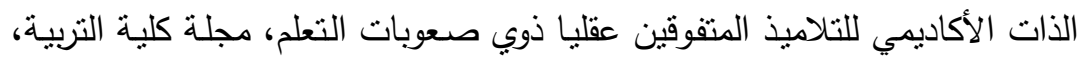

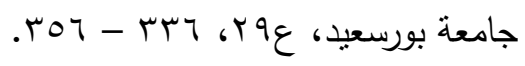

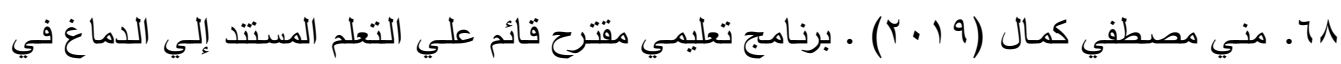

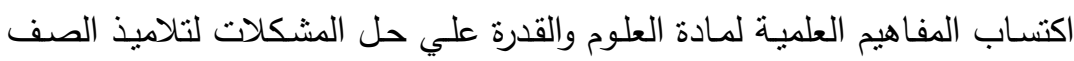

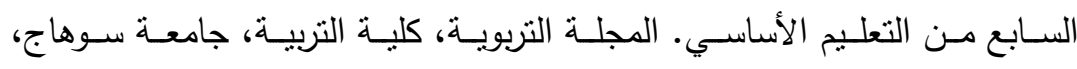

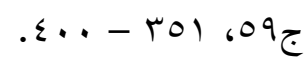

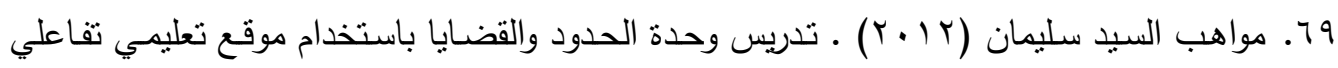

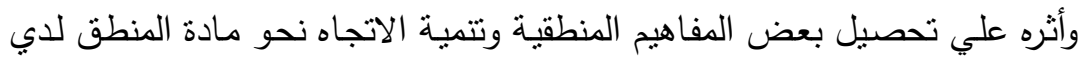

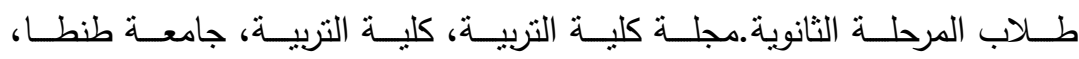

$$
\text { rrT - IVV ، } 6 \text { \& }
$$

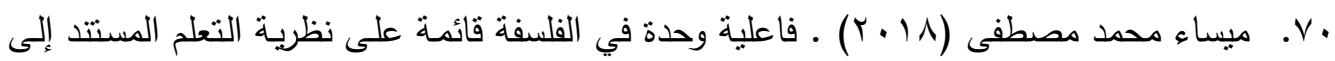

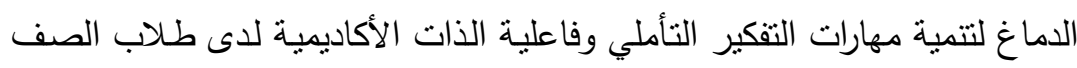

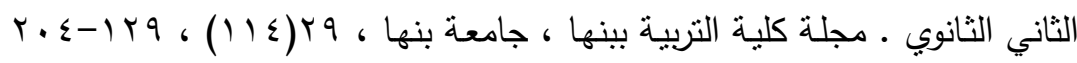

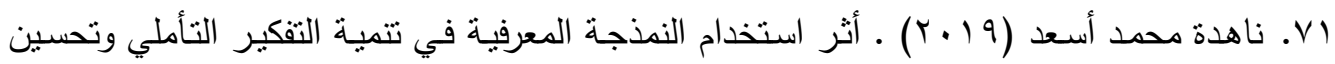

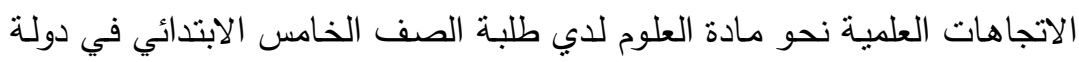

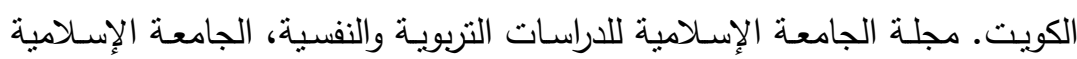

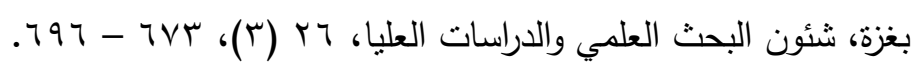

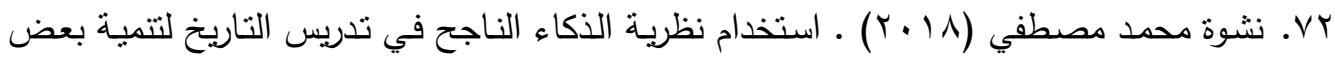

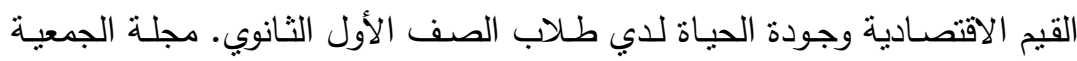

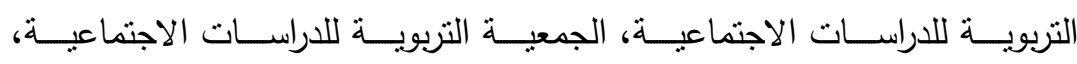

$$
\text { ع }
$$

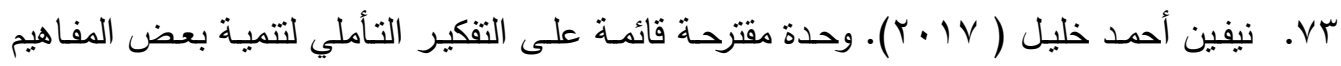

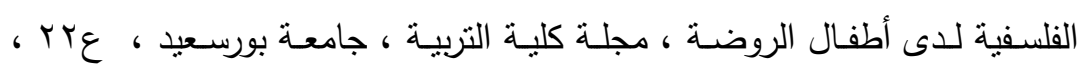

$$
\text { . r..-109 }
$$

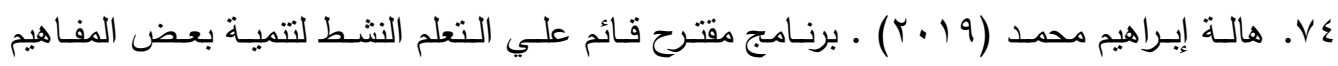

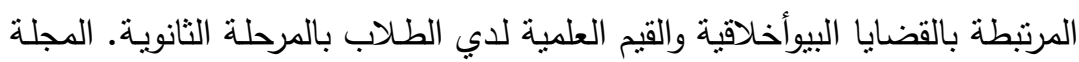

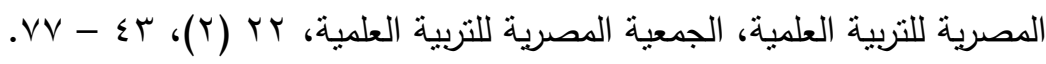




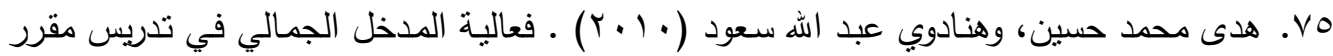
الأحياء علي فهم المفاهيم العلمية وطبيعة العلم والاتجاهات العلمية لدي طالبات الصف الأول الثانوي. المجلة المصرية للتربيـة العلميـة، الجمعية المصرية للتربية

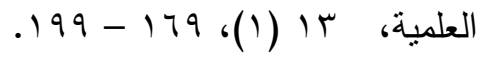

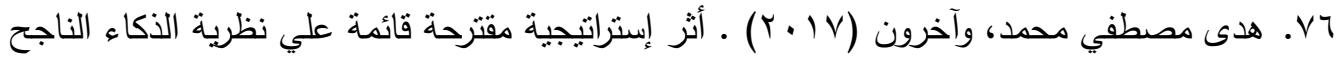

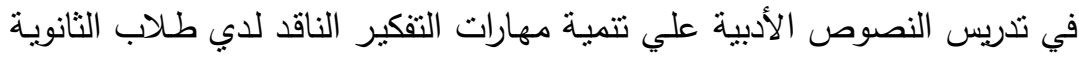
$\varepsilon$

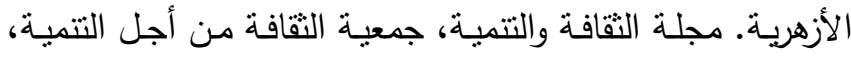

$$
.19 \leq-104 \text { 6) }
$$

VV

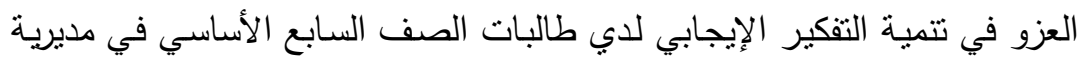

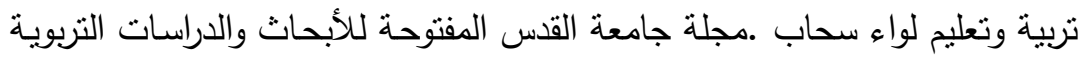

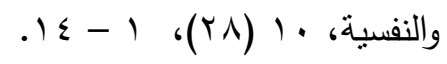

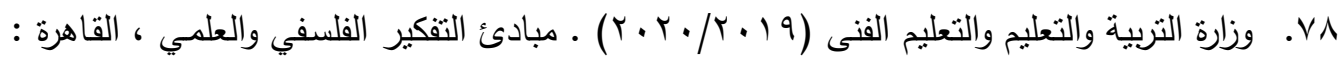

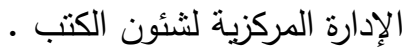

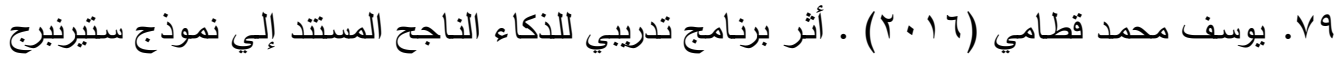

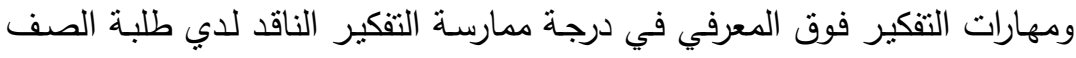

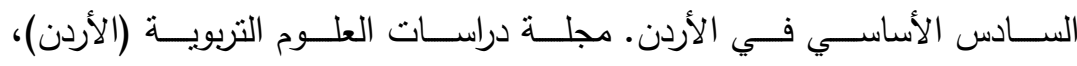
$.7 r 0-719 ،(\varepsilon r) r$

\section{ثانيا : المراجع الأجنبية :}

80. Baum,R. \& Bird, B.(2010).The Successful Intelligence of HighGrowth Entrepreneurs: Links to New Venture Growth .Organization Science,21(2), 397-412.

81. Bekhet ,A. \& Zauszniewski ,J.(2013). Measuring Use of Positive Thinking Skills: Psychometric Testing of a New Scale. Western Journal of Nursing Research, 35(8),1074 -1093.

82. Boulet,L.(2007). Coping Strategies and Successful Intelligence in Adults with Learning Disabilities. Master's Thesis, Mount Saint Vincent University, Canada.

83. Çelik, I. \& Sariçam, H.(2018). The Relationships Between Positive Thinking Skills, Academic Locus of Control and Grit in Adolescents. Universal Journal of Educational Research, 6(3),392-398. 
84. Denise M.(2017). The Mediating Effects of Positive Thinking and Social Support on Suicide Resilience Among Undergraduate Students . PhD, Marquette University, Wisconsin.

85. Ding, H.(2010). On the development of successful intelligence in chinese teaching. DAI, Hunan Normal University (People's Republic of China), United States.

86. Fang , C.(2011). A Study on the Relationship Between University Students' Regulatory Emotional Self-Efficacy and Positive Thinking. DAI, Huazhong Normal University (People's Republic of China) ,United States.

87. Grégoire , J. \& et..al(2015). Detecting and Correcting Misconceptions with Lifelike Avatars in 3D Learning Environments. Available at $:$ https:

$\angle$ aminer.org/archive/53e9bb2fb7602d970476d002.

88. Hamza , K. \& Wickman , P.(2008) . Describing and Analyzing Learning in Action: An Empirical Study of the Importance of Misconceptions in Learning Science .Science Education Journal,92(1).

89. Hunt ,E.(2008). Applying the Theory of Successful Intelligence to Education: The Good, the Bad, and the Ogre: Commentary on Sternberg Et..al. (2008). Perspectives on Psychological Science,3(6), 509-515.

90. Johnstone, J.\& et..al(2014). Prevention of Depression and Anxiety Symptoms in Adolescents: 42 and 54 Months Follow-up of the Aussie Optimism Program-Positive Thinking Skills. Front Psychol,v5.

91. Kelly, M.(2016). The Impact Of Positive Thinking And Empathy Induction On Social Perceptions Of Cancer. PhD, University of North Dakota, North Dakota.

92. Mysore,L. \& Vijayalaxmi ,A.(2018).Significance of Successful Intelligence in the Academics of Adolescents: a Literature Review. International Journal of Home Science , 4(1): 1316.

93. Nelson , B. \&et...al(2007). Clarification of Selected Misconceptions in Physical Geography . Journal of Geography , Available at www.wou.edu/ girodm/middle/Ne1son. 
94. Pallister,J_\&et...al(2014). The Efficacy of the Enhanced Aussie Optimism Positive Thinking Skills Program in Improving Social and Emotional Learning in Middle Childhood. Front Psychol Journal, v5.

95. Paxton, M.(2008). The Role of Positive Future Thinking in Adolescent Suicide risk. DAI, The Catholic University of America, United States.

96. Rogalla,M.(2003). Future Problem Solving Program Ccoaches' Efficacy in Teaching for Successful Intelligence and their Patterns of Successful Behavior. PhD, University of Connecticut, Switzerland.

97. RostamI,M.\&et..al(2014). The Effectiveness of Mental Rehabilitation Based on Positive Thinking Skills Training on Increasing Happiness in Hearing Impaired Adolescents. Audiol Journal.23(3),39-45.

98. Samavatian, M. \&, Latifi ,Z. (2014) . A Study to Investigate the Effectiveness of Successful Intelligence Training Program to Increase Academic Hope. Management Science Letters, $4(2), 389-392$.

99. Stemler, S. \& et..al(2006) . Using the Theory of Successful Intelligence as a Basis for Augmenting AP Exams in Psychology and Statistics. Contemporary Educational Psychology, 31(3), 344-376.

100. Stemler, S. \& et..al(2009).Using the Theory of Successful Intelligence as a Framework for Developing Assessments in AP Physics .Contemporary Educational Psychology, 34(3),195-209.

101. Sternberg, R.(2002).The Theory of Successful Intelligence and its Implications for Language a aptitude Testing, In: Robinson,P: Individual Differences and Instructed Language Learning, Amsterdam: John Benjamins Publishing Company, 13-43.

102. Sternberg,R.(2002). Raising the Achievement of All Students: Teaching for Successful Intelligence. Educational Psychology Review, v14, 383-393.

103. Sternberg,R,(2003). A Broad View of Intelligence: The Theory of Successful Intelligence. Consulting Psychology Journal: Practice \& Research, 55(3),139-154. 
104. Sternberg,R.(2005): The Theory of Successful Intelligence. Interamerican Journal of Psychology, 39(2), 189-202.

105. Sternberg, R.(2018).Speculations on the Role of Successful Intelligence in Solving Contemporary World Problems. Available at: www.mdpi.com

106. Sternberg, R. \& Grigorenko,E.(2002) . The Theory of Successful Intelligence as a Basis for Gifted Education. Gifted Child Quarterly Journal, 46(4),265-277.

107. Sternberg,R. \& Grigorenko,E.(2003).Teaching for Successful Intelligence: Principles, Procedures, and Practices. Journal for the Education of the Gifted ,Vol.27, No.2/3, 207-228.

108. Sternberg,R. \& Grigorenko ,E. (2004) . Successful Intelligence in the Classroom . Theory Into Practice, 43 (4) , 274-280 .

109. Sternberg,R.\&et...al(2014). Testing the Theory of Successful Intelligence in Teaching Grade 4 Language Arts, Mathematics, and Science. Journal of Educational Psychology, 106(3), 881-899.

110. Stojanovska, M. \& et..al(2012) . Addressing Misconceptions about the Particulate Nature of Matter among SecondarySchool and High-School Students in the Republic of Macedonia. Creative Education Journal , 3(5).

111. Thompson , F . \&.Logue , S.(2006) : An exploration of Common

Student Misconceptions in Science . International Education Journal, 7(4).

112. Wendy, M.\& et..al (2002) . Practical Intelligence for School: Developing Metacognitive Sources of Achievement in Adolescence. Developmental Review, 22(2) ,162- 210. 